National Water-Quality Assessment Program

\title{
Factors Affecting Groundwater Quality in the Valley and Ridge Aquifers, Eastern United States, 1993-2002
}

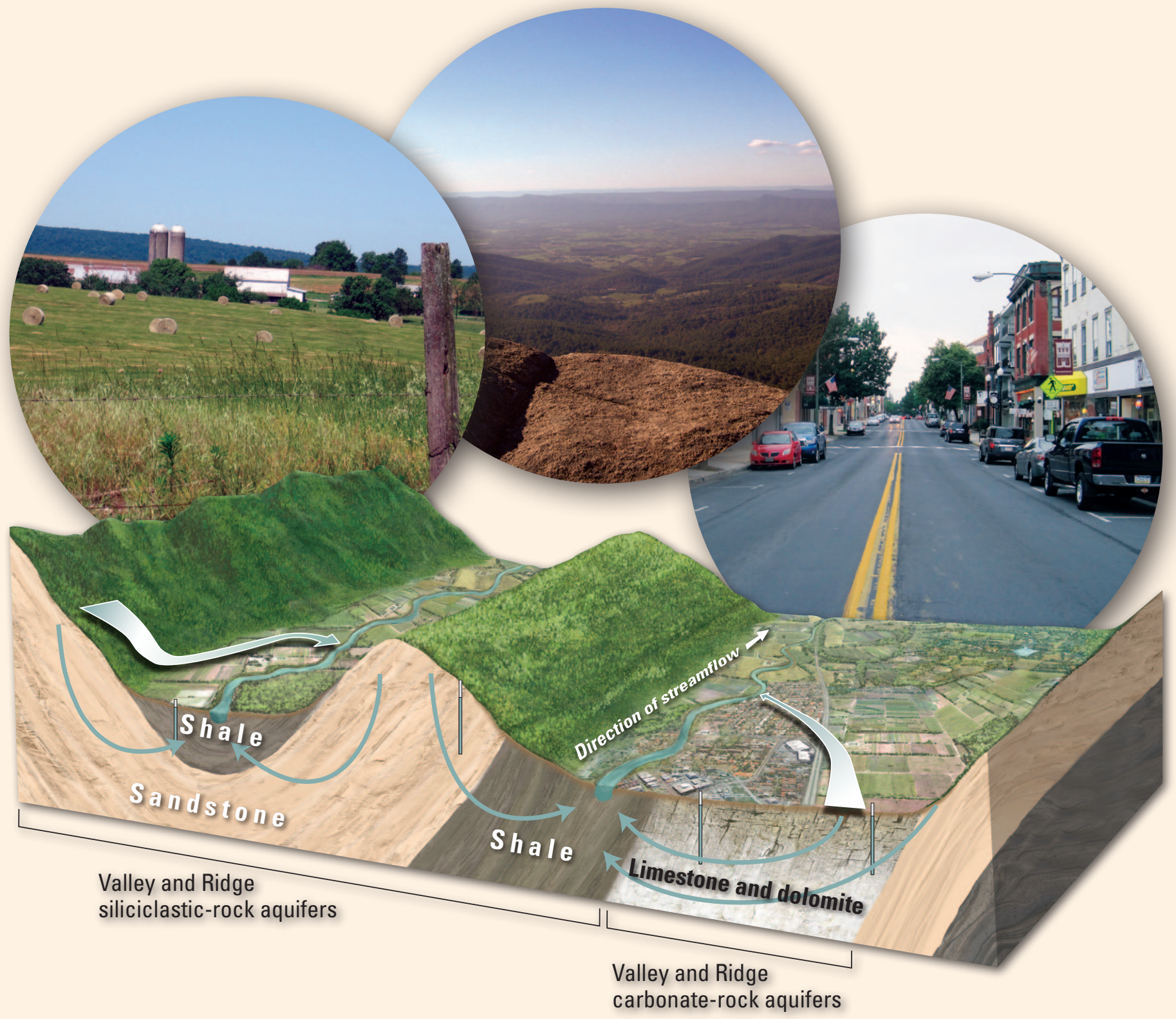

Scientific Investigations Report 2011-5115 



\section{Factors Affecting Groundwater Quality in the Valley and Ridge Aquifers, Eastern United States, 1993-2002}

By Gregory C. Johnson, Tammy M. Zimmerman, Bruce D. Lindsey, and Eliza L. Gross

National Water-Quality Assessment Program

Scientific Investigations Report 2011-5115 


\title{
U.S. Department of the Interior \\ KEN SALAZAR, Secretary \\ U.S. Geological Survey \\ Marcia K. McNutt, Director
}

\author{
U.S. Geological Survey, Reston, Virginia: 2011
}

For more information on the USGS - the Federal source for science about the Earth, its natural and living resources, natural hazards, and the environment, visit http://www.usgs.gov or call 1-888-ASK-USGS.

For an overview of USGS information products, including maps, imagery, and publications, visit http://www.usgs.gov/pubprod

To order this and other USGS information products, visit http://store.usgs.gov

Any use of trade, product, or firm names is for descriptive purposes only and does not imply endorsement by the U.S. Government.

Although this report is in the public domain, permission must be secured from the individual copyright owners to reproduce any copyrighted materials contained within this report.

Suggested citation:

Johnson, G.C., Zimmerman, T.M., Lindsey, B.D., and Gross, E.L., 2011, Factors affecting groundwater quality in the Valley and Ridge aquifers, eastern United States, 1993-2002: U.S. Geological Survey Scientific Investigations Report 2011-5115, 70 p. 


\section{Foreword}

The U.S. Geological Survey (USGS) is committed to providing the Nation with reliable scientific information that helps to enhance and protect the overall quality of life and that facilitates effective management of water, biological, energy, and mineral resources (http://WwW.usgs.gov/). Information on the Nation's water resources is critical to ensuring long-term availability of water that is safe for drinking and recreation and is suitable for industry, irrigation, and fish and wildlife. Population growth and increasing demands for water make the availability of that water, measured in terms of quantity and quality, even more essential to the long-term sustainability of our communities and ecosystems.

The USGS implemented the National Water-Quality Assessment (NAWQA) Program in 1991 to support national, regional, State, and local information needs and decisions related to water-quality management and policy (http://water.usgs.gov/ nawqa). The NAWQA Program is designed to answer: What is the quality of our Nation's streams and groundwater? How are conditions changing over time? How do natural features and human activities affect the quality of streams and groundwater, and where are those effects most pronounced? By combining information on water chemistry, physical characteristics, stream habitat, and aquatic life, the NAWQA Program aims to provide science-based insights for current and emerging water issues and priorities. From 1991 to 2001, the NAWQA Program completed interdisciplinary assessments and established a baseline understanding of water-quality conditions in 51 of the Nation's river basins and aquifers, referred to as Study Units (http://water.usgs.gov/nawqa/studies/study_units.htm/).

In the second decade of the Program (2001-2012), a major focus is on regional assessments of water-quality conditions and trends. These regional assessments are based on major river basins and principal aquifers, which encompass larger regions of the country than the Study Units. Regional assessments extend the findings in the Study Units by filling critical gaps in characterizing the quality of surface water and groundwater, and by determining water-quality status and trends at sites that have been consistently monitored for more than a decade. In addition, the regional assessments continue to build an understanding of how natural features and human activities affect water quality. Many of the regional assessments employ modeling and other scientific tools, developed on the basis of data collected at individual sites, to help extend knowledge of water quality to unmonitored, yet comparable areas within the regions. The models thereby enhance the value of our existing data and our understanding of the hydrologic system. In addition, the models are useful in evaluating various resourcemanagement scenarios and in predicting how our actions, such as reducing or managing nonpoint and point sources of contamination, land conversion, and altering flow and (or) pumping regimes, are likely to affect water conditions within a region.

Other activities planned during the second decade include continuing national syntheses of information on pesticides, volatile organic compounds (VOCs), nutrients, trace elements, and aquatic ecology; and continuing national topical studies on the fate of agricultural chemicals, effects of urbanization on stream ecosystems, bioaccumulation of mercury in stream ecosystems, effects of nutrient enrichment on stream ecosystems, and transport of contaminants to public-supply wells.

The USGS aims to disseminate credible, timely, and relevant science information to address practical and effective waterresource management and strategies that protect and restore water quality. We hope this NAWQA publication will provide you with insights and information to meet your needs, and will foster increased citizen awareness and involvement in the protection and restoration of our Nation's waters.

The USGS recognizes that a national assessment by a single program cannot address all water-resource issues of interest. External coordination at all levels is critical for cost-effective management, regulation, and conservation of our Nation's water resources. The NAWQA Program, therefore, depends on advice and information from other agencies-Federal, State, regional, interstate, Tribal, and local — as well as nongovernmental organizations, industry, academia, and other stakeholder groups. Your assistance and suggestions are greatly appreciated.

William H. Werkheiser

USGS Associate Director for Water 


\section{Contents}

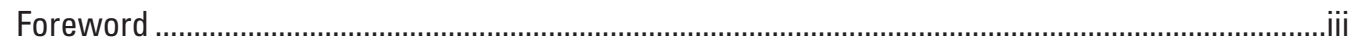

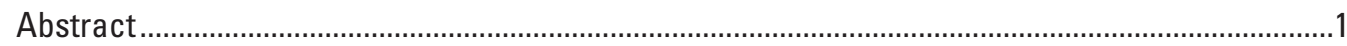

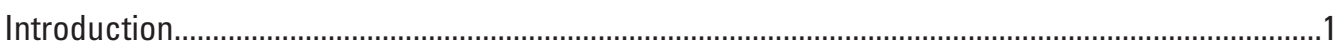

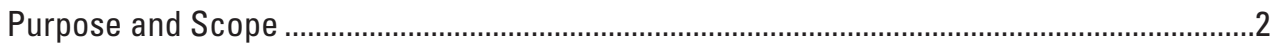

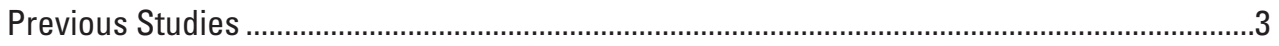

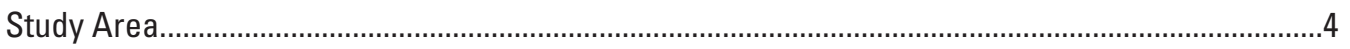

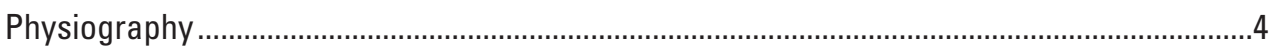

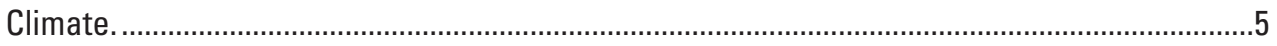

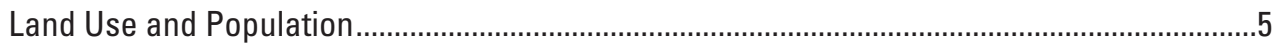

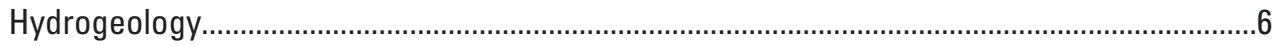

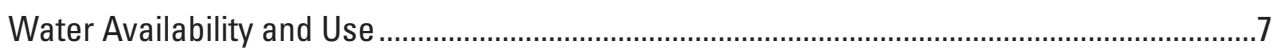

Data Sources and Methods ...................................................................................................

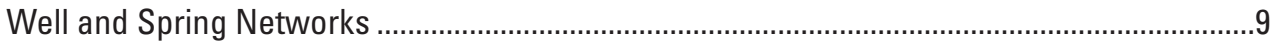

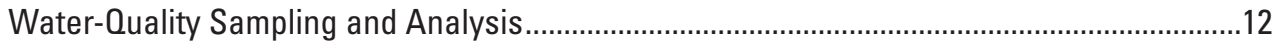

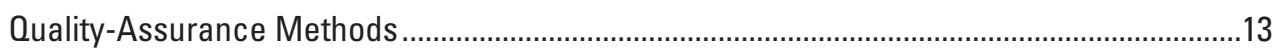

Human-Health Benchmarks........................................................................................13

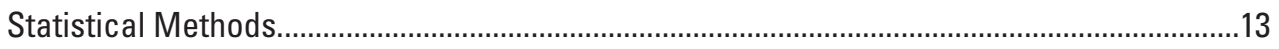

Geographic Information System Methods and Topographic Variables ...............................13

Groundwater Quality in the Valley and Ridge Aquifers .............................................................16

Basic Groundwater Properties and Chemical Composition ...................................................16

Residence Time, Oxygen, and Chemical Equilibria ………...................................................20

Water Quality in Relation to Land Use and Topography........................................................22

Selected Contaminants in Groundwater from the Valley and Ridge Aquifers and the Factors that Affect Their Occurrence ...................................................................26

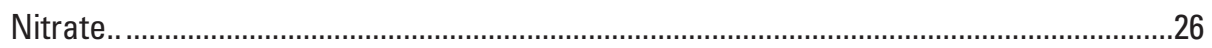

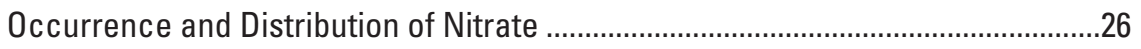

Factors Affecting Nitrate Concentrations ..........................................................29

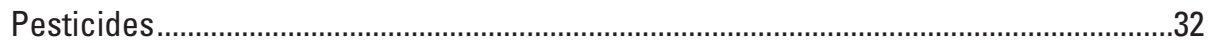

Occurrence and Distribution of Pesticides .............................................................35

Assessment of Potential Effects of Pesticides on Human Health ..............................35

Factors Affecting Occurrence of Frequently Detected Pesticides ..........................40

Other Pesticides Analyzed ......................................................................................

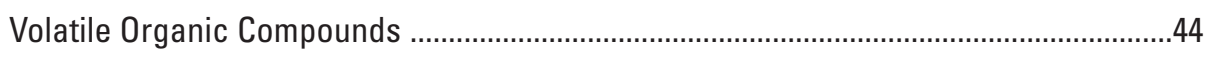

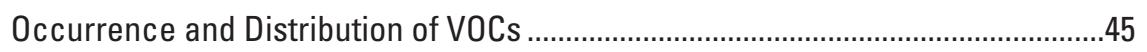

Assessment of Potential Effects of VOCs on Human Health ....................................48

Factors Affecting Occurrence of VOCs................................................................

Fecal-Indicator Bacteria ....................................................................................51

Occurrence and Distribution of Fecal-Indicator Bacteria .....................................51

Factors Affecting Occurrence of Fecal-Indicator Bacteria ......................................52 


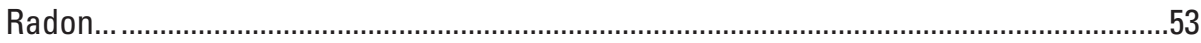

Occurrence and Distribution of Radon ..................................................................5

Factors Affecting Concentrations of Radon ...................................................................54

Distribution of Sites with Background Concentration and Sites with Evidence of

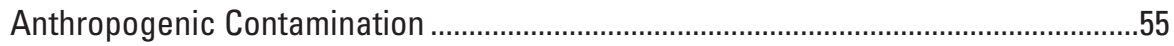

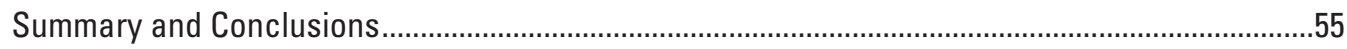

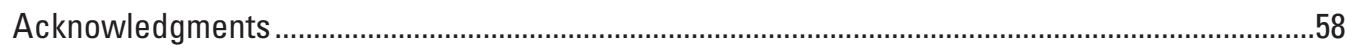

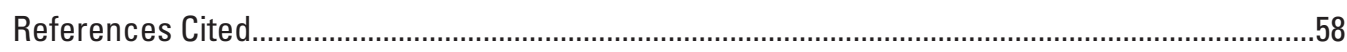

\section{Figures}

1. Map showing Valley and Ridge aquifers and the major river basins from which water-quality samples were collected...

2. Map showing land-use categories overlying the Valley and Ridge aquifers in 1992........4

3. Box plots showing well depths, casing lengths, and water levels for well networks in the Valley and Ridge aquifers, 1993-2002

4. Cross section indicating locations of topographic variables, normalized lateral position variables, and topographic sections......

5. Map showing examples of calculating distance to nearest topographic divide and distance to nearest major stream in central Pennsylvania

6. Box plots showing specific conductance, $\mathrm{pH}$, dissolved oxygen, total dissolved solids, and alkalinity for water samples from networks in the Valley and Ridge aquifers, 1993-2002

7. Box plots showing concentrations of constituents and calcite saturation index values for groundwater samples from networks in the Valley and Ridge aquifers, 1993-2002

8. Box plots showing concentrations of constituents by lithologic group for groundwater samples from the Valley and Ridge aquifers, 1993-2002

9. Graph showing groundwater residence time distribution in the Valley and Ridge carbonate- and siliciclastic-rock aquifers

10. Pie charts showing dominant redox processes by aquifer type and groundwater age

11. Block diagram illustrating distribution of land use with respect to topography and aquifer type in the Valley and Ridge

12. Box plots showing distribution of specific conductance, dissolved oxygen concentrations, and $\mathrm{pH}$ by topographic section and aquifer type, for the Valley and Ridge aquifers, 1993-2002

13. Cross section of Shenandoah Valley illustrating distribution of groundwater residence time...

14. Diagram showing distribution of wells, land use surrounding wells, and dominant redox states by topographic sections within Valley and Ridge carbonate-rock aquifers, 1993-2002. 
15. Diagram showing distribution of wells, land use surrounding wells, and dominant redox states by topographic sections within Valley and Ridge siliciclastic-rock aquifers, 1993-2002

16. Map showing nitrate distribution in the Valley and Ridge aquifers, 1993-2002 ..............27

17. Box plots showing nitrate concentrations by network for samples from the Valley and Ridge aquifers, 1993-2002.

18. Box plots showing nitrate concentrations in groundwater samples from the Valley and Ridge aquifers grouped by land use and aquifer type, 1993-2002.

19. Box plots showing distribution of nitrate concentrations by topographic section and aquifer type in the Valley and Ridge aquifers, 1993-2002 .....

20. Map showing sample locations and pesticide detection frequency at any concentration in groundwater samples from wells and springs in the Valley and Ridge aquifers, 1993-2002

21. Graphs showing groundwater samples with zero, one to two, three to four, and five or more pesticide compounds at any concentration in relation to, $A$, groundwater network, $B$, redox state, $C$, land-use classification, and, $D$, aquifer type

22. Box plots showing distribution of, $A$, atrazine and, $B$, metolachlor concentrations in groundwater samples from well and spring networks in the Valley and Ridge aquifers, 1993-2002

23. Graphs showing concentrations and benchmark quotient values of the most common pesticides in areas underlain by carbonate- and siliciclastic-rock aquifers stratified by various land-use categories in the Valley and Ridge aquifers, 1993-2002

24. Box plots showing distribution of atrazine, deethylatrazine, simazine, prometon, and metolachlor concentrations by combined land use/aquifer setting in the Valley and Ridge aquifers, 1993-2002.

25. Map showing volatile organic compounds detected at a concentration greater than 0.2 micrograms per liter in the Valley and Ridge aquifers, 1993-2002 . .46

26. Graphs showing detection frequency for samples with volatile organic compounds detected at the 0.2-microgram per liter assessment level by, $A$, groundwater network and, $B$, land-use classification and by, $C$, redox state and, $D$, aquifer type for samples in the Valley and Ridge aquifers, 1993-2002.

27. Graphs showing concentrations and benchmark quotients of the most common volatile organic compounds in various land-use categories in the Valley and Ridge siliciclastic-rock and carbonate-rock aquifers, 1993-2002.

28. Graph showing percentage of detections by redox state for selected volatile organic compounds in the Valley and Ridge aquifers, 1993-2002.

29. Graph showing ratio of detection frequencies in oxic and anoxic samples for selected volatile organic compounds in the Valley and Ridge aquifers, 1993-2002.

30. Box plots showing detection frequency and distribution of concentrations of Escherichia coli bacteria in groundwater samples from well and spring networks in the Valley and Ridge aquifers, 1993-2002..

31. Box plots showing detection frequency and distribution of concentrations of Escherichia coli bacteria in groundwater samples by aquifer type in the Valley and Ridge aquifers, 1993-2002.

32. Box plots showing detection frequency of Escherichia coli bacteria in groundwater samples from wells by land-use group in the Valley and Ridge aquifers, 1993-2002 
33. Graph showing detection frequency of Escherichia coli bacteria in groundwater samples from wells by land-use group and aquifer type in the Valley and Ridge aquifers, 1993-2002

34. Box plots showing distribution of radon levels in groundwater samples among carbonate- and siliciclastic-rock aquifers in the Valley and Ridge aquifers, 1993-2002. 54

35. Box plots showing distribution of radon levels in groundwater samples by lithologic group and aquifer type in the Valley and Ridge aquifers, 1993-2002

36. Graph showing normalized lateral position and dissolved oxygen concentration in groundwater samples from the Valley and Ridge aquifers, 1993-2002, for sites with background concentrations consisting of no detects for volatile organic compounds or pesticides and nitrate less than 2 milligrams per liter, and sites of concern which had pesticide or volatile organic compound concentrations greater or equal to 0.1 times health benchmark values or nitrate greater than or equal to 10 milligrams per liter

\section{Tables}

1. Land use categories for major geologic subdivisions of the Valley and Ridge aquifers, 1992

2. Lithologic groups and hydrogeologic terranes in the Valley and Ridge aquifers .............6

3. Description of groundwater networks sampled in the Valley and Ridge aquifers, 1993-2002.

4. Summary of sampled constituent groups in groundwater networks in the Valley and Ridge aquifers, 1993-2002

5. Summary of soil characteristics within a 1,640-foot radius of wells and springs in groundwater networks in the Valley and Ridge aquifers.

6. Summary of generalized land-use categories in the groundwater networks in the Valley and Ridge aquifers, 1993-2002.

7. General land-use designation guidelines for wells and springs in the Valley and Ridge aquifers

8. Description of topographic variables derived using geographic information system methods

9. Threshold concentrations for identifying oxidation-reduction designation

10. Spearman's rho correlations between groundwater age and well construction or water chemistry

11. Spearman's rho correlations between normalized lateral position and water chemistry for Valley and Ridge carbonate-rock aquifers (without springs) and for selected topographic sections, 1993-2002.

12. Spearman's rho correlations between normalized lateral position and water chemistry for Valley and Ridge siliciclastic-rock aquifers and for selected topographic sections, 1993-2002.

13. Summary of Spearman's rho correlations between nitrate concentrations and explanatory variables for normalized lateral position and general water-quality values in groundwater in the Valley and Ridge aquifers, 1993-2002 
14. Summary of Spearman's rho correlations between nitrate concentrations and explanatory variables for land use and nitrogen sources in groundwater in the Valley and Ridge aquifers, 1993-2002.

15. Sources of nitrogen in groundwater networks in the Valley and Ridge aquifers, 1990-2002

16. Summary of Spearman's rho correlations between nitrate concentrations in groundwater and explanatory variables for hydrogeology and soils for the Valley and Ridge aquifers, 1993-2002.

17. Detection frequency of 47 pesticides in wells and springs in the Valley and Ridge aquifers, 1993-2002.

18. Summary of pesticide detections at any concentration for selected pesticides in individual well networks and springs in the Valley and Ridge aquifers, 1993-2002

19. Physical properties of selected pesticides detected in the Valley and Ridge aquifers, 1993-2002

20. Summary of pesticide compounds most frequently applied in basins in the Valley and Ridge aquifers

21. Summary of Spearman's rho correlations between frequently detected pesticide concentrations and selected site-specific and source variables in groundwater in the Valley and Ridge aquifers, 1993-2002.

22. Summary of Spearman's rho correlations between frequently detected pesticide concentrations in groundwater and normalized lateral position by aquifer type in the Valley and Ridge aquifers, 1993-2002.

23. Detection frequency of 63 pesticides, pesticide degradates, and organic compounds using High Performance Liquid Chromatography and High Performance Liquid Chromatography/Mass Spectrometry for groundwater samples from wells and springs in the Valley and Ridge aquifers, 1993-2002 .66

24. Detection frequency of 87 volatile organic compounds in groundwater samples from the Valley and Ridge aquifers, 1993-2003.

25. Number of volatile organic compounds detected, percentage of sites with detections by volatile organic compound group, and number of compounds detected in each volitile organic compound group for groundwater samples from networks in the Valley and Ridge aquifers, 1993-2002.

26. Percentage of samples with detections by redox state, and the oxic/anoxic ratio of detection frequencies for selected volatile organic compounds in groundwater samples from the Valley and Ridge aquifers, 1993-2002 


\section{Conversion Factors and Datums}

\begin{tabular}{|c|c|c|}
\hline Multiply & By & To obtain \\
\hline \multicolumn{3}{|c|}{ Length } \\
\hline foot $(\mathrm{ft})$ & 0.3048 & meter $(\mathrm{m})$ \\
\hline mile (mi) & 1.609 & kilometer (km) \\
\hline \multicolumn{3}{|c|}{ Area } \\
\hline square mile $\left(\mathrm{mi}^{2}\right)$ & 2.590 & square kilometer $\left(\mathrm{km}^{2}\right)$ \\
\hline \multicolumn{3}{|c|}{ Flow rate } \\
\hline million gallons per day (Mgal/d) & 0.04381 & cubic meter per second $\left(\mathrm{m}^{3} / \mathrm{s}\right)$ \\
\hline inch per hour (in/h) & 0.0254 & meter per hour $(\mathrm{m} / \mathrm{h})$ \\
\hline inch per year (in/yr) & 25.4 & millimeter per year (mm/yr) \\
\hline \multicolumn{3}{|c|}{ Radioactivity } \\
\hline picocurie per liter $(\mathrm{pCi} / \mathrm{L})$ & 0.037 & becquerel per liter $(\mathrm{Bq} / \mathrm{L})$ \\
\hline
\end{tabular}

Temperature in degrees Celsius $\left({ }^{\circ} \mathrm{C}\right)$ may be converted to degrees Fahrenheit $\left({ }^{\circ} \mathrm{F}\right)$ as follows:

${ }^{\circ} \mathrm{F}=\left(1.8 x^{\circ} \mathrm{C}\right)+32$

Temperature in degrees Fahrenheit $\left({ }^{\circ} \mathrm{F}\right)$ may be converted to degrees Celsius $\left({ }^{\circ} \mathrm{C}\right)$ as follows:

${ }^{\circ} \mathrm{C}=\left({ }^{\circ} \mathrm{F}-32\right) / 1.8$

Vertical coordinate information is referenced to the North American Vertical Datum of 1988 (NAVD 88).

Horizontal coordinate information is referenced to the North American Datum of 1983 (NAD 83).

Altitude, as used in this report, refers to distance above the vertical datum.

Specific conductance is given in microsiemens per centimeter at 25 degrees Celsius $\left(\mu \mathrm{S} / \mathrm{cm}\right.$ at $\left.25^{\circ} \mathrm{C}\right)$.

Concentrations of chemical constituents in water are given either in milligrams per liter (mg/L) or micrograms per liter $(\mu \mathrm{g} / \mathrm{L})$.

Soil organic carbon-water partition coefficient is given in milliliters per gram $(\mathrm{mL} / \mathrm{g})$.

Concentrations of bacteria in water are reported in colonies per 100 milliliters (col/100 mL). 
(This page intentionally left blank.) 


\title{
Factors Affecting Groundwater Quality in the Valley and Ridge Aquifers, Eastern United States, 1993-2002
}

\author{
By Gregory C. Johnson, Tammy M. Zimmerman, Bruce D. Lindsey, and Eliza L. Gross
}

\section{Abstract}

Chemical and microbiological analyses of water from 230 wells and 35 springs in the Valley and Ridge Physiographic Province, sampled between 1993 and 2002, indicated that bedrock type (carbonate or siliciclastic rock) and land use were dominant factors influencing groundwater quality across a region extending from northwestern Georgia to New Jersey. The analyses included naturally occurring compounds (major mineral ions and radon) and anthropogenic contaminants [pesticides and volatile organic compounds (VOCs)], and contaminants, such as nitrate and bacteria, which commonly increase as a result of human activities. Natural factors, such as topographic position and the mineral composition of underlying geology, act to produce basic physical and geochemical conditions in groundwater that are reflected in physical properties, such as $\mathrm{pH}$, temperature, specific conductance, and alkalinity, and in chemical concentrations of dissolved oxygen, radon, and major mineral ions. Anthropogenic contaminants were most commonly found in water from wells and springs in carbonate-rock aquifers. Nitrate concentrations exceeded U.S. Environmental Protection Agency maximum contaminant levels in 12 percent of samples, most of which were from carbonate-rock aquifers. Escherichia coli (E. coli), pesticide, and VOC detection frequencies were significantly higher in samples from sites in carbonate-rock aquifers. Naturally occurring elements, such as radon, iron, and manganese, were found in higher concentrations in siliciclastic-rock aquifers. Radon levels exceeded the proposed maximum contaminant level of 300 picocuries per liter in 74 percent of the samples, which were evenly distributed between carbonate- and siliciclastic-rock aquifers. The land use in areas surrounding wells and springs was another significant explanatory variable for the occurrence of anthropogenic compounds. Nitrate and pesticide concentrations were highest in samples collected from sites in agricultural areas and lowest in samples collected from sites in undeveloped areas. Volatile organic compounds were detected most frequently and in highest concentrations in samples from sites in urban areas, and least frequently in agricultural and undeveloped areas. No volatile organic compound concentrations and concentrations from only one pesticide, dieldrin, exceeded human-health benchmarks.

\section{Introduction}

The Valley and Ridge Physiographic Province of the eastern United States stretches from Alabama to Pennsylvania, spans nine states, and covers approximately 46,000 square miles $\left(\mathrm{mi}^{2}\right)$ (fig. 1). Groundwater in this province (hereafter simply termed the "Valley and Ridge") is an important source of water for public and domestic supply. Although most public water supplies in the Valley and Ridge rely heavily on surfacewater sources (Hutson and others, 2004), about 4 million people, roughly half of the region's population, live in rural areas (U.S. Bureau of the Census, 1999, 2001a, 2001b) where many people rely on unregulated domestic wells for water. Generally, data from domestic water-supply wells regarding groundwater quality and related human-health concerns are limited - especially for pesticides and volatile organic compounds (VOCs).

Groundwater quality can be affected by a number of physical characteristics of wells or springs and by the land surrounding them. These characteristics may include land use and soil conditions at the surface as well as the deeper bedrock geology (lithology, mineralogy, chemical composition, and structure) of the principal aquifers from which water is drawn. About half of the Valley and Ridge is underlain by carbonaterock aquifers, which are particularly susceptible to contamination from the land surface through relatively rapid recharge and groundwater flow through karst conduits (Quinlan and others, 1991; Field, 1993; Leibundgut, 1998; Stueber and Criss, 2005; Lindsey and others, 2009). How this contamination influences the quality of water in local wells and springs also may be related to soil thickness and topographic position of wells in relation to contaminant sources.

The U.S. Geological Survey (USGS) National WaterQuality Assessment Program (NAWQA) conducted a series of investigations from 1993 to 2002 to evaluate the quality of the groundwater in major river basins throughout the 


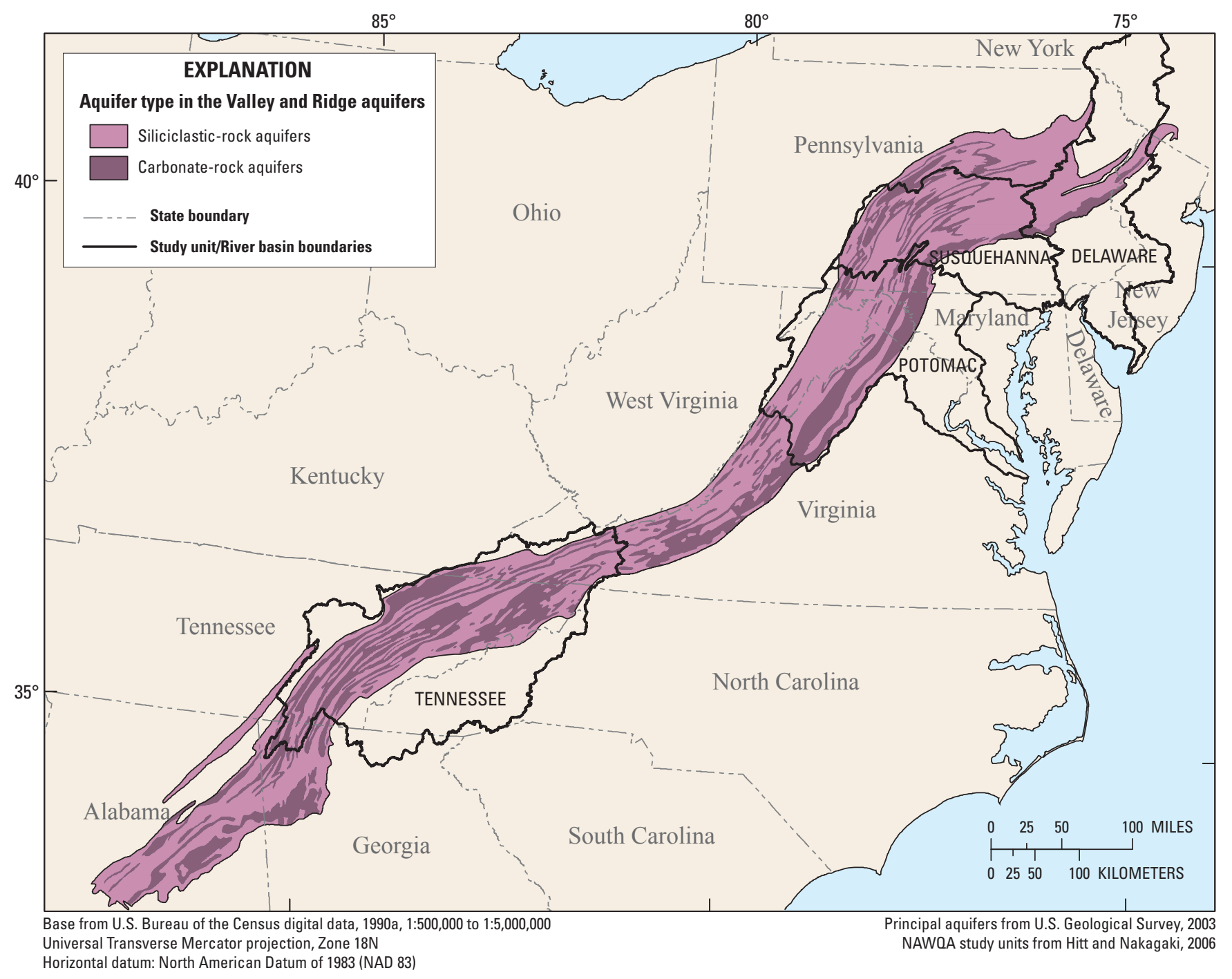

Figure 1. Valley and Ridge aquifers and the major river basins from which water-quality samples were collected.

eastern United States, including parts of aquifers in the Valley and Ridge. Individual NAWQA groundwater investigations included areas of four major river basins in the Valley and Ridge (Delaware, Susquehanna, Potomac, and Tennessee River basins) and identified several natural and man-made contaminants in groundwater at concentrations that can affect human health (Ator and others, 1998; Lindsey and others, 1998; Hampson and others, 2000; Fischer and others, 2004). The compilation of results of multiple NAWQA investigations focused on the Valley and Ridge aquifers produced a comprehensive and quality-assured dataset. This dataset has been used in this study to address important questions concerning factors that can degrade or improve groundwater quality and concerning the possible consequences for human health for those using groundwater as a source of domestic supply from these aquifers.

\section{Purpose and Scope}

This report is a compilation and analysis of groundwater quality and factors affecting the occurrence and distribution of selected constituents in aquifers of the Valley and Ridge. The analysis will (1) provide a geographic and topographic framework to examine groundwater quality, (2) identify constituents of concern related to human health, and (3) describe controls, such as land use and aquifer type, on groundwater quality across the region. The data presented in this report were collected in parts of Georgia, Tennessee, Virginia, Maryland, Pennsylvania, and New Jersey. Data included analyses of samples from 230 wells and 35 springs collected from 1993 to 2002. The analyses included $\mathrm{pH}$, temperature, specific conductance, alkalinity, dissolved oxygen, dissolved organic carbon (DOC), and major ions. Analytes of potential human health 
concern included nutrients, pesticides, pesticide degradation products, VOCs, and radon. Fecal-indicator bacteria also were enumerated for selected samples.

\section{Previous Studies}

Regional groundwater quality of the Valley and Ridge was described by Briel (1997) as part of the USGS Regional Aquifer-System Analysis study, which resulted in the analysis of major ions and nutrients in 3,012 wells and 428 springs. Water quality also was evaluated in regional studies presented in a series of hydrologic atlases of the United States (Miller, 1990; Lloyd and Lyke, 1995; Trapp and Horn, 1997) and was summarized by state in the USGS National Water Summaries (U.S. Geological Survey, 1985, 1988). Numerous other watershed, statewide, and small-scale investigations have also been done.

A national study of water quality in carbonate-rock aquifers indicated that water from wells in carbonate-rock aquifers in the Valley and Ridge had some of the highest concentrations of nitrate and the highest frequencies of detection for pesticides when compared to 11 other carbonate aquifers (Lindsey and others, 2009). High concentrations of nitrate in groundwater were attributed to the intensity of agricultural activity in the Valley and Ridge, the lack of confining layers, and the presence of organic carbon. Open karst conduits at the land surface, abundant contamination sources, and short residence times make carbonate aquifers of the Valley and Ridge highly vulnerable to contaminant migration (Lindsey and others, 2009).

Studies of groundwater in the major river basins in the Valley and Ridge have been described in a series of reports. Lindsey and others (1997) reported that nitrate levels in groundwater for agricultural areas in the Susquehanna River basin were significantly higher where underlain by carbonate rock as compared to sandstone and shale for similar nitrogen inputs. Nitrate concentrations in water from siliciclastic-rock aquifers in the Susquehanna River basin appear to reflect a two-layer system described by Schnabel and others (1993), Gburek and Folmar (1999), and Lindsey and others (2003). In such a system, nitrate concentrations tend to be high in an upper shallow layer of highly fractured bedrock where transmissivities are high and water is relatively young, and tend to be lower in deeper, less fractured rock where transmissivities are lower, water is older, and conditions favor denitrification (Lindsey and others, 1997).

Ator and Denis (1997) reported that in the Potomac River basin, concentrations of nitrate in groundwater were higher in agricultural and urban areas than in forested areas and were highest overall where agriculture was underlain by carbonate rock. The authors observed that elevated nitrate concentrations in water from the carbonate-rock aquifers may indicate enhanced transport through karst but also may reflect a higher density of agricultural land use in areas underlain by carbonate rocks in the Potomac River basin and associated higher rates of fertilizer use in such areas. Further, Ferrari and Ator
(1995) found that nitrate concentrations in groundwater in the Potomac River basin were higher in areas dominated by crop production as compared to livestock grazing, and Donnelly and Ferrari (1997) reported that pesticide detections also were more frequent in water samples from sites in agricultural areas over carbonate-rock aquifers.

Johnson (2002) examined water quality in 35 springs flowing from carbonate-rock aquifers in the Valley and Ridge area of the Tennessee River basin. Fecal-indicator bacteria were in water samples from all 35 springs, VOCs were present in samples from 30 springs, and pesticides were detected in samples from 24 springs. In subsequent sampling of eight community water-supply sources in the area (four wells and four springs), culturable viruses were present in three of the six samples from "low-risk" sites (three wells and one spring) identified by prior analysis of fecal indicators and susceptibility factors such as the thickness of overburden, and in six of the eight samples from "high-risk" sites (Johnson and others, 2010). In Pennsylvania, Lindsey and others (2002) reported culturable viruses in water from 2 of the 25 wells in carbonaterock aquifers, in 1 of 25 wells in crystalline-rock aquifers, and in 1 of the 5 wells completed in siliciclastic-rock aquifers in the Valley and Ridge, Piedmont, and Blue Ridge Physiographic Provinces.

Bickford and others (1996) reported that fecal-indicator bacteria were more prevalent in water from household supply wells completed in carbonate-rock aquifers in the Great Valley and Appalachian Mountain regions of the Susquehanna River basin than in water from wells completed in either siliciclastic-rock or crystalline-rock aquifers in those regions or from carbonate-rock aquifers in the Piedmont Physiographic Province. Total coliform, fecal coliform, and fecal streptococcus bacteria concentrations were higher in groundwater from agricultural areas as compared to non-agricultural areas and were most strongly related to land use and physiographic province. Escherichia coli (E. coli) concentrations also were significantly higher in water from wells in areas underlain by carbonate bedrock. A subsequent study reported detections of $E$. coli bacteria only in water from wells in carbonaterock aquifers, with highest detection frequency in wells that were not grouted along the entire casing (Zimmerman and others, 2001).

A recent study of the effect of sinkholes on water quality (Lindsey and others, 2010) reported that groundwater in areas with a high density of sinkholes was more likely to contain detectable concentrations of some contaminants. Detection frequencies of the pesticides prometon and metolachlor in groundwater were highest in areas with the highest sinkhole density, although detection frequency of other pesticides and concentrations of nitrate in groundwater were not significantly different among areas of differing sinkhole density in the Valley and Ridge carbonate-rock aquifers (Lindsey and others, 2010). As an indication of overall karst development, high sinkhole density was related to greater spring discharge, a higher density of caves, and more developed conduit flow systems. 


\section{Study Area}

The Valley and Ridge Physiographic Province (Fenneman, 1938) extends about 1,200 miles (mi) from near Scranton, Pennsylvania, to Birmingham, Alabama, and encompasses approximately $46,000 \mathrm{mi}^{2}$ of the eastern United States (figs. 1 and 2; Swain and others, 1991). The width of this mountainous region averages about $50 \mathrm{mi}$ but varies from $80 \mathrm{mi}$ in central Pennsylvania to $65 \mathrm{mi}$ in Maryland, to $40 \mathrm{mi}$ in Tennessee (Davies, 1968). The province takes its name from the characteristic topographic sequence of alternating ridges and stream valleys, which are roughly oriented parallel to the long northeast-to-southwest axis of the province (Fenneman, 1938).

\section{Physiography}

The Valley and Ridge is part of the mountainous area of the eastern United States called the Appalachian Highlands Physiographic Division (Fenneman and Johnson, 1946). The province is bordered on the east by the Blue Ridge Physiographic Province and on the northeast by the Piedmont Physiographic Provinces. It is bounded to the west by the Appalachian Plateaus Physiographic Province and directly north by the St. Lawrence Valley Physiographic Province (Fenneman and Johnson, 1946). The western boundary of the Valley and Ridge is easily distinguished topographically and is known as the Allegheny Front in Pennsylvania, Maryland, and West Virginia and as the Cumberland Escarpment in Virginia

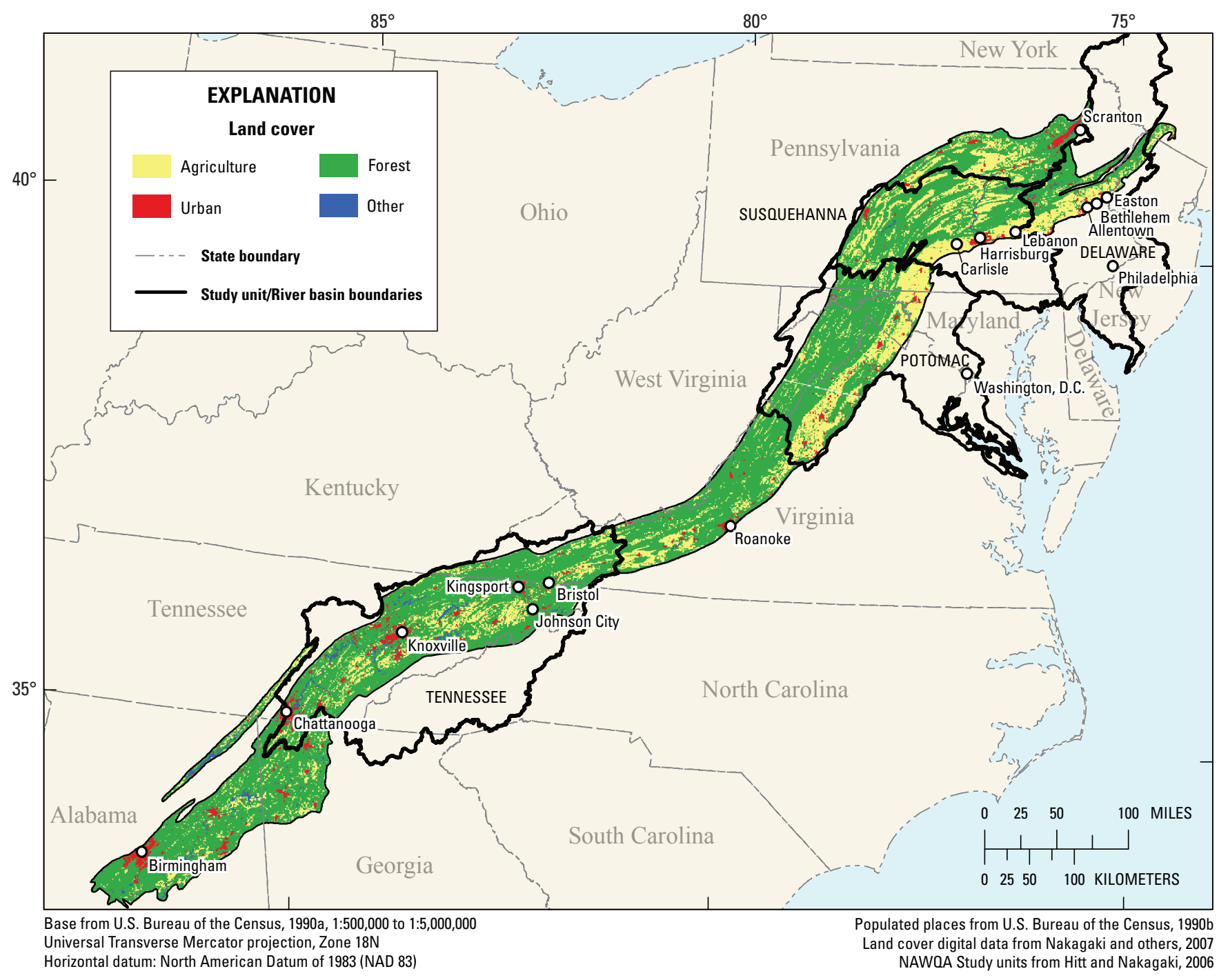

Figure 2. Land-use categories overlying the Valley and Ridge aquifers in 1992. 
and Tennessee (U.S. Army Corps of Engineers, 2001). The boundary is not visually distinct everywhere the Valley and Ridge meets the Blue Ridge Physiographic Province in the east. The mountains of the Blue Ridge Physiographic Province are underlain mainly by complex metamorphic and igneous rocks, which produce a thick apron of colluvium and alluvium at the boundary. This layer of colluvium and alluvium, which overlies and is unevenly eroded into the fine-grained residuum and dolomite of the Valley and Ridge, forms the Elkton aquifer (Hollyday and Hileman, 1996).

The Valley and Ridge is underlain mainly by deformed sedimentary rocks of Cambrian to Pennsylvanian age that intersect the surface to form long, narrow northeast-trending ridges and valleys overlying metamorphic and igneous rock of Precambrian age (Meyer, 1965). These sedimentary rocks were originally deposited as horizontal layers, but over time were folded, faulted, fractured, and weathered into a highly deformed bedrock foundation overlain by unconsolidated regolith ranging in texture from clay to gravel and varying in thickness from 0 to 450 feet (ft) (Hollyday and Hileman, 1996). Sedimentary formations in this area are composed predominantly of two rock types: carbonate rock including limestone and dolomite in places variously interbedded with each other or with shale, and siliciclastic rock, which is mostly sandstone and shale but also includes siltstone, conglomerate, and mixed sandstone and shale (Hollyday and Hileman, 1996; Harlow and others, 2004). The order of abundance of these rocks is shale (37.4 percent), dolomite ( 21.0 percent), sandstone (16.3 percent), limestone (13.8 percent), siltstone (4.6 percent), mudstone (1.0 percent), and graywacke (1.0 percent). Other non-carbonate rocks can be found in lesser abundance, including quartzite, granitic gneiss, chert, basalt, granulite, slate, and minor occurrences of metamorphic and crystalline rock. These others, however, represent only about 4.9 percent of bedrock geology in the province (Dicken and others, 2005a, 2005b; Nicholson and others, 2005, 2007) and are not discussed in this report.

\section{Climate}

Reflecting the region's geographic extent, average annual temperatures in the Valley and Ridge vary widely from north to south. From 1971 to 2000, the lowest average annual temperature in northeastern extreme (Pennsylvania) was about 5.7 degrees Celsius $\left({ }^{\circ} \mathrm{C}\right)$; the highest average annual temperature at the southern extreme (northeastern Alabama and northwestern Georgia) was about $17.3{ }^{\circ} \mathrm{C}$ (PRISM Group at Oregon State University, 2006a). The average minimum temperature in January was $-7.6^{\circ} \mathrm{C}$ in the north and $6.8^{\circ} \mathrm{C}$ in the south. In July average temperatures reach about $17.0^{\circ} \mathrm{C}$ in the north and $26.9^{\circ} \mathrm{C}$ in the south (PRISM Group at Oregon State University, 2006b).

Average annual precipitation also varies across the province but not in a consistent way from north to south. Over the 30-year period 1971-2000, precipitation varied across the entire province from less than 40 inches per year (in/yr) to greater than $70 \mathrm{in} / \mathrm{yr}$. Precipitation was greatest in the southern part of the province and lowest in the mid-latitudes. Locally, precipitation is influenced by orographic effects and prevailing weather patterns. Annual precipitation was greatest in the western part of the Valley and Ridge in Tennessee, averaging about $70 \mathrm{in} / \mathrm{yr}$ and least in eastern West Virginia, averaging only about $32 \mathrm{in} / \mathrm{yr}$ (PRISM Group at Oregon State University, 2006c).

\section{Land Use and Population}

The predominant land use in 1992 in the Valley and Ridge was forest, which covered about 65 percent of the area (fig. 2, table 1). Agriculture covered about 26 percent of the area, and urban development covered about 6 percent of the area (Vogelmann and others, 2001; Nakagaki and Wolock, 2005; Price and others, 2007). The relative proportion of land uses in the province varied somewhat from north to south,

Table 1. Land use categories for major geologic subdivisions of the Valley and Ridge aquifers, 1992.

$\left[\mathrm{mi}^{2}\right.$, square miles]

\begin{tabular}{|c|c|c|c|c|c|c|c|}
\hline \multirow[b]{2}{*}{ Geology } & \multirow[b]{2}{*}{ Area } & \multicolumn{6}{|c|}{ Land-cover classifications ${ }^{1}$} \\
\hline & & Water & Developed & $\begin{array}{l}\text { Bare rock/ } \\
\text { quarries }\end{array}$ & Forest & $\begin{array}{l}\text { Row crop/ } \\
\text { hay pasture }\end{array}$ & Wetlands \\
\hline Carbonate & Percent & 1.6 & 9.6 & 0.7 & 50.1 & 37.4 & 0.6 \\
\hline Siliciclastic & Area $\left(\mathrm{mi}^{2}\right)$ & 368 & 1,140 & 253 & 21,300 & 5,750 & 139 \\
\hline \multirow[t]{2}{*}{ Total } & Area $\left(\mathrm{mi}^{2}\right)$ & 626 & 2,660 & 368 & 29,200 & 11,700 & 235 \\
\hline & Percent & 1.4 & 5.9 & 0.8 & 65.3 & 26 & 0.5 \\
\hline
\end{tabular}

\footnotetext{
${ }^{1}$ Land-cover classification from Nakagaki and others (2007).
} 
tending toward greater agricultural use in the north. Twentynine percent of land north of the Tennessee-Virginia line, for example, was agricultural compared to 20 percent south of that line. Areas overlying carbonate-rock aquifers tended to have less forested land use and somewhat higher agricultural and urban land use (50 percent forest, 37 percent agriculture, and 10 percent urban) than areas overlying siliciclastic-rock aquifers (74 percent forest, 20 percent agriculture, and 4 percent urban).

In 2000, the population of the Valley and Ridge was approximately 8 million people, and about half of this population lived in rural areas (U.S. Bureau of the Census, 2001a, 2001b). The remainder were concentrated in several metropolitan statistical areas (MSAs), including Birmingham, Alabama (777,640 people); Chattanooga, Tennessee $(445,205)$; Knoxville, Tennessee $(687,531)$; Johnson City-Kingsport-Bristol, Tennessee-Virginia (479,398); Roanoke, Virginia (177,425); Harrisburg-Lebanon-Carlisle, Pennsylvania (588,984); and Allentown-Bethlehem-Easton, Pennsylvania $(513,120)$ (U.S. Bureau of the Census, 1999, 2001a, 2001b). MSA populations were calculated by multiplying the census block group population densities by the fraction of area within the Valley and Ridge. Of these, Allentown-Bethlehem-Easton, Pennsylvania, was reported as having the densest population (586 persons per square mile). Overall, the population of the Valley and Ridge is about evenly split between those living in areas of predominately carbonate rock (50.2 percent) and areas of predominately siliciclastic rock (49.8 percent) (U.S. Bureau of the Census, 2001a, 2001b; Dicken and others, 2005a, 2005b; Nicholson and others, 2005, 2007).

\section{Hydrogeology}

Hydrogeologic terranes are regionally contiguous areas characterized by similar rock type and water-yielding properties. Hollyday and Hileman (1996) developed a classification of hydrogeologic terranes to group aquifers of the Valley and Ridge on the basis of these properties. Based on 12 rock types, they classified hydrologic terranes into 5 types: alluvium, dolomite, limestone, argillaceous carbonate rock, and siliciclastic rock (table 2). In the context of this report, these terranes can be grouped into two major aquifer types.

Table 2. Lithologic groups and hydrogeologic terranes in the Valley and Ridge aquifers.

[N/A, no data in that category; principal aquifer from U.S. Geological Survey, 2003]

\begin{tabular}{|c|c|c|c|}
\hline $\begin{array}{c}\text { Hydrogeologic terranes } \\
\text { (Hollyday and Hileman, 1996) }\end{array}$ & $\begin{array}{l}\text { Lithologic descriptor group } \\
\text { (Hollyday and Hileman, 1996) }\end{array}$ & $\begin{array}{l}\text { Lithologic groups } \\
\text { (this report) }\end{array}$ & Principal aquifer \\
\hline \multirow{2}{*}{ Alluvium } & Sand & N/A & N/A \\
\hline & Sand and gravel & N/A & N/A \\
\hline Dolomite & Limestone and dolomite & Limestone and dolomite & \multirow{3}{*}{ Carbonate } \\
\hline \multirow{2}{*}{ Argillaceous carbonate rock } & Limestone and shale & \multirow{2}{*}{ N/A } & \\
\hline & Dolomite and shale & & \\
\hline \multirow{4}{*}{ Siliciclastic rock } & Conglomerate & $\mathrm{N} / \mathrm{A}$ & \multirow{4}{*}{ Siliciclastic } \\
\hline & Sandstone and shale & \multirow{3}{*}{ Mixed siliciclastic } & \\
\hline & Sandstone & & \\
\hline & Siltstone & & \\
\hline
\end{tabular}


Carbonate-rock aquifers in the Valley and Ridge consist mainly of fractured limestone and dolomite with localized solution-enlarged conduits. Siliciclastic-rock aquifers consist primarily of fractured sandstone but may include fractured shale and have been described by Trapp and Horn (1997) as "undifferentiated sedimentary rock aquifers." The term "siliciclastic-rock aquifers" is used in this report to emphasize the contrast with carbonate-rock aquifers in terms of mineralogy, hydraulic characteristics, and structural properties.

Carbonate-rock aquifers in the Valley and Ridge are characterized by karst features such as sinkholes and solution openings. The term "karst" describes a landscape underlain by rocks in which chemical dissolution has enlarged joints, fractures, bedding planes, or other openings through which water flows (Quinlan and others, 1991). Groundwater levels in karst conduit systems can fluctuate up to tens of feet during periods as short as a few hours or days (Milanovic, 1981; Quinlan and Ewers, 1985; Wolfe, 1996), and groundwater velocities in such systems can be relatively high even in areas with low hydraulic gradients (Nelms and others, 2003). These systems may have several layers of networked conduits and discharge points whose relative importance varies with groundwater level (White, 1988).

In the Valley and Ridge, solution openings in carbonate-rock aquifers may extend to a depth of up to $500 \mathrm{ft}$ in places, reflecting the steep vertical dip of interbedded rock strata (Wolfe and others, 1997). Most solution openings, however, are confined to a depth of $300 \mathrm{ft}$ or less (Brahana and others, 1986). Groundwater storage also can be substantial in the regolith and along bedrock fractures, joints, and bedding planes.

Springs in karst settings are generally of three types: (1) depression springs, where the water table intersects a low spot in the land surface; (2) contact springs, where an impervious layer directs water to an outcrop; and (3) tubular springs, where solution openings are under positive hydrostatic pressure at the surface (Sun and others, 1963). Tubular springs tend to be more common in the southern three-fourths of the Valley and Ridge where groundwater may discharge from single large openings at rates as high as 67.3 million gallons per day (Mgal/d) (Hollyday and Smith, 1990). Spring flow tends to concentrate into a few large openings, rather than many small openings. The geologic transition at the eastern boundary with the Blue Ridge also creates a unique hydrologic setting, which results in highly productive wells and springs in solution openings in the dolomite bedrock overlain by thick mantles of coarse alluvium and colluvium and fine-grained residuum (Hollyday and Hileman, 1996).

The movement of water in siliciclastic-rock aquifers in the Valley and Ridge is fundamentally different from that in carbonate-rock aquifers. In the absence of large solution openings, water in siliciclastic-rock aquifers moves primarily through permeable regolith and along fractures, joints, and bedding planes. Groundwater storage is concentrated in the same features (Nelms and others, 2003).

\section{Water Availability and Use}

The geologic complexity of the Valley and Ridge results in a large variation of water-yielding properties among and between the carbonate-rock and siliciclastic-rock aquifers, and the yield of a single aquifer unit may vary by four orders of magnitude over its geographic extent (Hollyday and Hileman, 1996). McGuinness (1963) found that yields from carbonaterock aquifers in the Valley and Ridge are highly variable. Clastic shale and siltstone formations generally have the lowest yields, sandstone formations have intermediate yields, and carbonate rocks have the highest yields. Locally, however, even shales may produce water adequate for use when sufficiently fractured (Seaber and others, 1988).

Taken in aggregate, the repeating sequences of interbedded rock types (carbonate and siliciclastic rocks) and other lithologic variation within types, in combination with the strike-oriented drainage networks that define the Valley and Ridge, have the effect of isolating groundwater into many local and relatively shallow flow systems. Hydraulic gradients naturally follow topographic relief and run from ridge to valley. In a folded terrain, this often means that flow paths along major hydraulic gradients are directed across strike where they may be intercepted and redirected at exposed joints. Because of this, flow paths are commonly indirect and follow alternative directions, first along and then perpendicular to prevailing gradients. Coarse-grained carbonate rock with well-developed secondary porosity and fracture zones tend to be more permeable and may act to collect or channel water (Seaber and others, 1988).

Estimated groundwater recharge to the Valley and Ridge aquifers was calculated based on an analysis of base flow of streams and mean annual runoff during the period 1951-1980 (Wolock, 2003). Comparisons of the rainfall and recharge illustrate the complex relation between the two factors. The lowest average annual recharge rate occurred in northwestern Maryland in the siliciclastic-rock aquifers and was about $4 \mathrm{in} / \mathrm{yr}$ (compared to precipitation of $37.5 \mathrm{in} / \mathrm{yr}$ ). The highest average annual recharge rate occurred in southeastern Tennessee (also in the siliciclastic-rock aquifers) and was about $21 \mathrm{in} / \mathrm{yr}$ (rainfall is $55 \mathrm{in} / \mathrm{yr}$ ).

Although population in the province was evenly split between those living in areas underlain by the two rock types (carbonate and siliciclastic), groundwater use from carbonaterock aquifers tends to be much greater, which perhaps reflects greater availability. Total groundwater withdrawals from carbonate-rock aquifers in 2000 were about 267 million gallons per day (Mgal/d), which was composed of irrigation, publicsupply, and self-supplied industrial water withdrawals of 5.65, 177 , and 83.9 Mgal/d, respectively (Maupin and Barber, 2005). In contrast, withdrawals from siliciclastic-rock aquifers were considerably less at a total of about $95 \mathrm{Mgal} / \mathrm{d}$, or $0.61,48.9$, and $45.5 \mathrm{Mgal} / \mathrm{d}$ for irrigation, public-supply, and self-supplied industrial uses, respectively (Maupin and Barber, 2005). Selfsupplied domestic withdrawals from the Valley and Ridge aquifers was $110 \mathrm{Mgal} / \mathrm{d}$ in 2005 (Maupin and Arnold, 2010). 


\section{Data Sources and Methods}

The analysis presented in this report is based on a compilation of results derived from 11 USGS NAWQA investigations completed in 4 major river basins over a period of 9 years beginning in June 1993 (table 3). Overall, these data come from one of two general kinds of sampling networks. Seven networks were designed to document the characteristics of groundwater quality within a single land use (forest, agriculture, urban, or "reference"), and four "major aquifer networks" were designed to document groundwater quality within a single aquifer type (carbonate or siliciclastic) without regard to land use. In general, sampling protocols, analytical techniques, and quality-assurance standards were consistent among these studies though the purposes of these studies and the objectives of site selection have varied. The combined datasets were tested for significant differences across the Valley and Ridge and were compared to human-health benchmark standards to identify issues of concern. Finally, the influences of geologic and topographic factors on groundwater quality were evaluated using a combination of spatial and statistical analysis.

Table 3. Description of groundwater networks sampled in the Valley and Ridge aquifers, 1993-2002.

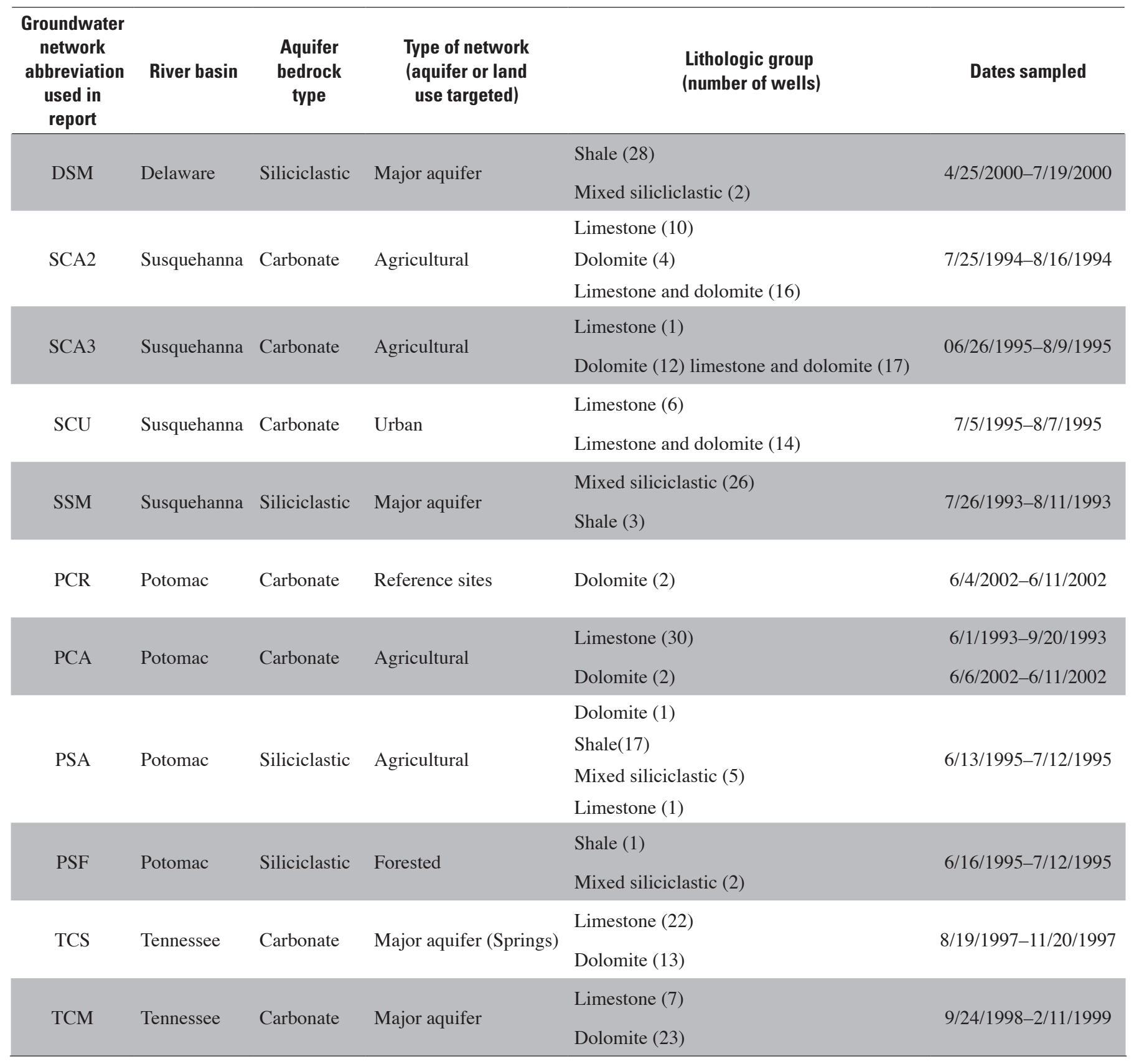




\section{Well and Spring Networks}

Data from each of the networks included in this analysis are identified for clarity using an abbreviated, three- or fourcharacter naming convention for the wells and networks from which they were derived (table 3 ). The first character of each well name (denoted as D, S, P, or T) indicates the major river basin (Delaware, Susquehanna, Potomac, or Tennessee River basin) in which the study was conducted. The second character in each name ( $\mathrm{C}$ or $\mathrm{S})$ indicates the aquifer bedrock type (carbonate or siliciclastic, respectively); the third character indicates the purpose of the network (major-aquifer wells, M; major-aquifer springs, S; agriculture, A; urban, U; forest, F; or reference, R). A fourth character, present in two instances, indicates a sequence of networks for similar investigations at different times. For example, SCA2 and SCA3 were both designed as an agricultural land-use study on carbonate-rock aquifers in the Susquehanna River basin.

The number of wells included in these networks varied between a minimum of 2 for the Potomac River basin reference network (PCR) and a maximum of 35 for the Tennessee River basin spring network (TCS) but typically ranged between 20 and 30 wells (table 4). Groundwater samples from nearly all of the 265 wells or springs were analyzed for concentrations of nutrients, major ions, and a suite of pesticides. A different set of groundwater samples (190 samples) was analyzed for concentrations of selected VOCs, and yet another set of 190 samples was analyzed for bacteria. Where more than one sample set was available for a given well, the set encompassing the most complete analytical schedule was favored.

Though the depths of sampled wells ranged from less than $50 \mathrm{ft}$ to more than $600 \mathrm{ft}$, the median depths of all wells within the networks were less than $250 \mathrm{ft}$; median well casing depths were less than $100 \mathrm{ft}$, and median depths to water were less than about $65 \mathrm{ft}$ (fig. 3). Wells were deepest in the Tennessee carbonate-rock aquifer (TCM) network, which included three public supply wells and three commercial wells. However, the deepest wells in this network were domestic supply wells that were drilled into rock of poor primary porosity where greater depths are sometimes required to produce adequate yield or borehole storage. Wells were shallowest in the Susquehanna carbonate-rock aquifer urban (SCU) network.

Soil characteristics were summarized for a 1,640-ft radius surrounding each well for comparison to patterns in groundwater quality and anthropogenic contamination (table 5). Soil permeability, thickness, organic-matter content, and particlesize class were area-averaged from the State Soil Geographic Database (STATSGO; U.S. Department of Agriculture, Natural Resources Conservation Service, 1994; Wolock, 1997), and hydraulic runoff potential (in hydrologic groups) was derived from an enhanced version of STATSGO (Barbara C. Ruddy and William A. Battaglin, U.S. Geological Survey, written commun., 1998) using an interpolation technique described by Foth and Schafer (1980). Runoff potential was categorized into four hydraulic groups from lowest potential (A) to highest (D) (U.S. Department of Agriculture, 1986). Nitrogen inputs from specific anthropogenic sources were estimated for the

Table 4. Summary of sampled constituent groups in groundwater networks in the Valley and Ridge aquifers, 1993-2002.

\begin{tabular}{lcccccc}
\hline \multirow{2}{*}{$\begin{array}{c}\text { Groundwater } \\
\text { network' }\end{array}$} & $\begin{array}{c}\text { Number of } \\
\text { wells or } \\
\text { springs }\end{array}$ & Nutrients & Major ions & Pesticides & $\begin{array}{c}\text { Volatile organic } \\
\text { compounds }\end{array}$ & Bacteria \\
\cline { 3 - 6 } & 30 & 30 & 30 & 29 & 30 & 30 \\
\hline DSM & 30 & 30 & 30 & 30 & 9 & 30 \\
SCA2 & 30 & 30 & 30 & 30 & 20 & 28 \\
SCA3 & 20 & 20 & 20 & 20 & 20 & 8 \\
SCU & 29 & 29 & 29 & 29 & 29 & 29 \\
SSM & 2 & 2 & 2 & 2 & 0 & 0 \\
PCR & 32 & 31 & 32 & 32 & 17 & 0 \\
PCA & 24 & 23 & 22 & 24 & 0 & 0 \\
PSA & 3 & 3 & 3 & 3 & 0 & 0 \\
PSF & 35 & 35 & 35 & 35 & 35 & 35 \\
TCS & 30 & 30 & 30 & 30 & 30 & 30 \\
TCM & $\mathbf{2 6 5}$ & $\mathbf{2 6 3}$ & $\mathbf{2 6 3}$ & $\mathbf{2 6 4}$ & $\mathbf{1 9 0}$ & $\mathbf{1 9 0}$ \\
Total & & & & & & \\
\hline
\end{tabular}

${ }^{1}$ Groundwater network abbreviations are defined in table 3 . 

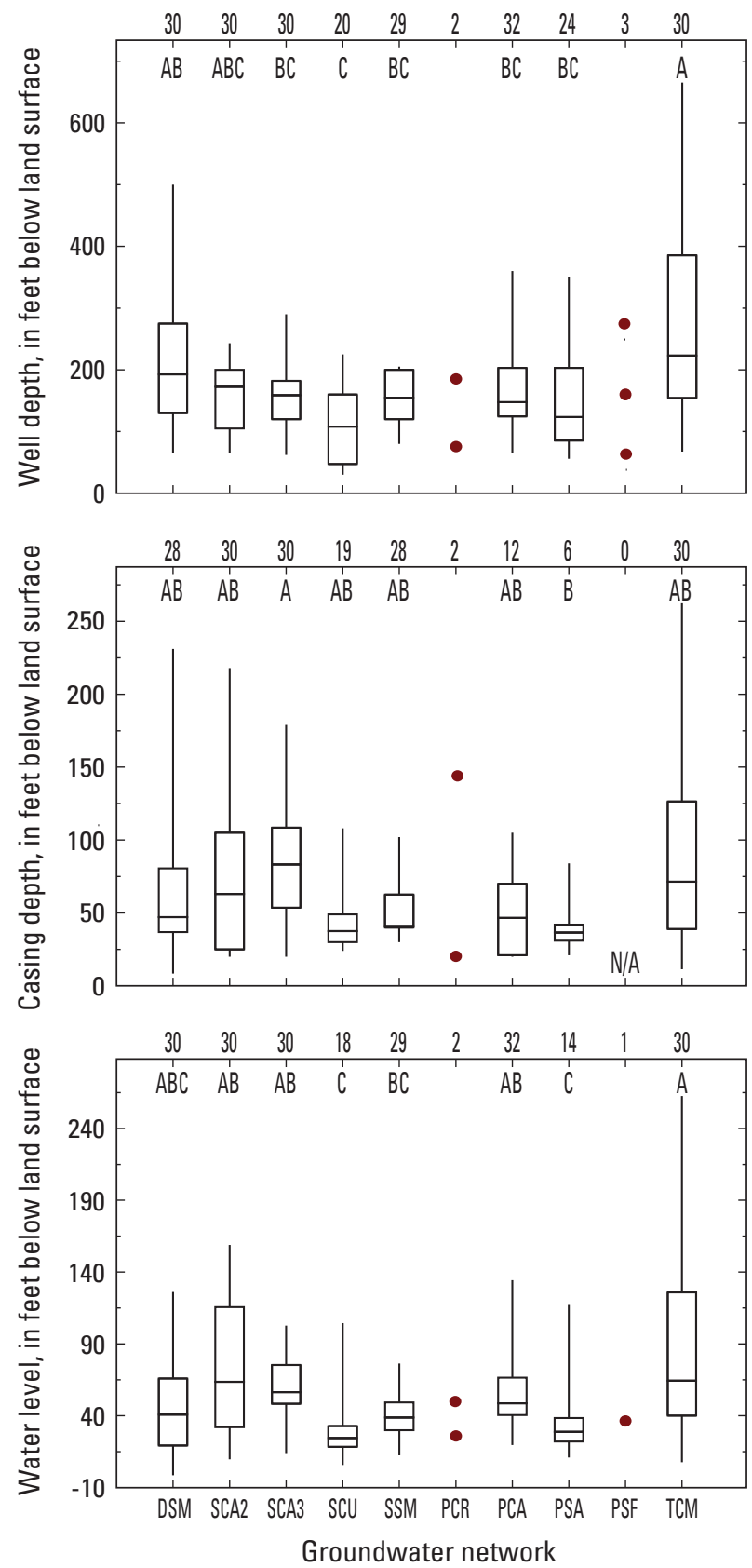

EXPLANATION

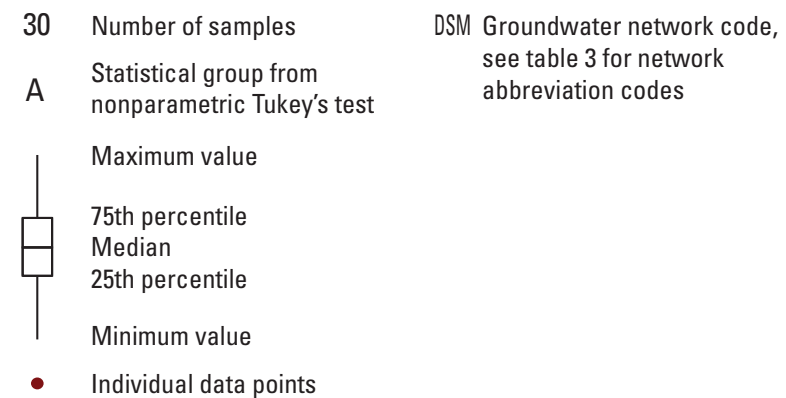

Figure 3. Well depths, casing lengths, and water levels for well networks in the Valley and Ridge aquifers, 1993-2002. 


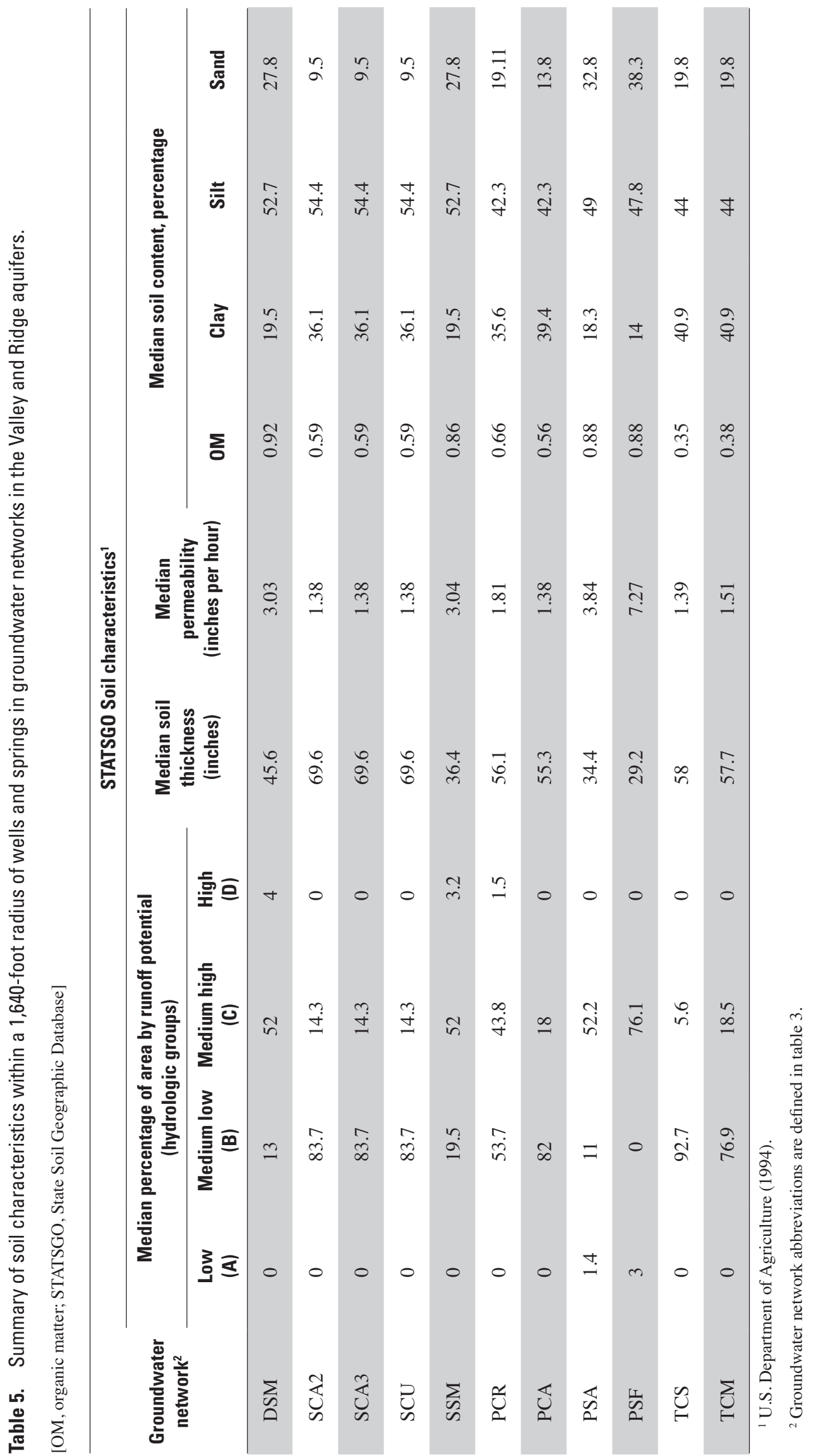


following categories: septic systems, atmospheric deposition, agricultural fertilizer use, non-agricultural fertilizer use, manure from confined animal operations, and manure from unconfined animals (Ruddy and others, 2006).

Land-use characteristics were determined for a 1,640$\mathrm{ft}$ radius around each well (table 6), based on a 30-meter resolution digital land-use map from Price and others (2007). Agricultural land use included any combination of row crops, pasture, and hay. Urban land use included residential, commercial, and industrial areas. Forest included deciduous, coniferous, and mixed forests. For some analytical comparisons, individual wells were further assigned to predominant land-use categories under one of four general designations (agricultural, urban, undeveloped, and mixed; table 7) following Gilliom and others (2006).

\section{Water-Quality Sampling and Analysis}

Groundwater and spring-flow samples were collected using consistent protocols and were analyzed at the USGS National Water Quality Laboratory in Denver, Colorado. Well selection and installation guidelines are described in Lapham and others (1997). Water-quality samples initially were collected using field protocols described in Koterba and others (1995) and described in the USGS National Field Manual (U.S. Geological Survey, variously dated). Springs were sampled using groundwater protocols with the sampling pump placed as close to the spring orifice as possible (Johnson, 2002).

Table 6. Summary of generalized land-use categories in the groundwater networks in the Valley and Ridge aquifers, 1993-2002.

\begin{tabular}{|c|c|c|c|}
\hline \multirow[t]{2}{*}{$\begin{array}{c}\text { Groundwater } \\
\text { network }^{2}\end{array}$} & \multicolumn{3}{|c|}{$\begin{array}{l}\text { Land use within a 1,640-foot radius } \\
\text { of wells and springs }{ }^{1} \\
\text { ( median value in percent) }\end{array}$} \\
\hline & Agricultural & Urban & Forested \\
\hline DSM & 32.8 & 0 & 63.3 \\
\hline SCA2 & 97.1 & 0 & 2.5 \\
\hline SCA3 & 98.1 & 0 & 1.8 \\
\hline SCU & 11.7 & 74 & 1.7 \\
\hline SSM & 77.4 & 0 & 19.1 \\
\hline PCR & 10.3 & 7.6 & 80.3 \\
\hline PCA & 88.6 & 0 & 8.6 \\
\hline PSA & 60.6 & 0 & 36.4 \\
\hline PSF & 0.7 & 0 & 99.7 \\
\hline TCS & 30.1 & 0.8 & 58.3 \\
\hline $\mathrm{TCM}$ & 33.2 & 0.3 & 56.9 \\
\hline
\end{tabular}

${ }^{1}$ Price and others, 2007.

${ }^{2}$ Groundwater network abbreviations are defined in table 3.
Nutrient analyses included nitrogen concentrations in several forms (nitrite plus nitrate, nitrite, ammonia, and ammonia plus organic nitrogen) and phosphorus concentrations in two forms (orthophosphate and total). As a rule, nitrate concentrations are determined by subtraction of nitrite from nitrate plus nitrite concentrations. Because nitrite concentrations were very low [less than $(<) 0.1$ milligram per liter $(\mathrm{mg} / \mathrm{L})]$ in 86 percent of samples, nitrate plus nitrite and nitrate concentrations were assumed to be equivalent for all samples. Hereafter, the laboratory reported value for nitrite plus nitrate as nitrogen concentration is simply referred to as nitrate concentration.

Forty-seven pesticides and degradation products were analyzed using gas chromatography/mass spectrometry (GC/MS) with selected ion monitoring (Zaugg and others, 1995). A second set of 38 pesticides and pesticide degradation products (Werner and others, 1996) was analyzed using high performance liquid chromatography (HPLC) at 242 of the 265 sites, and a third set of 25 pesticides and other organic compounds (Furlong and others, 2001) was analyzed using high performance liquid chromatography/mass spectrometry (HPLC/MS) at 46 sites.

Samples from 190 wells and springs were analyzed for various fecal-indicator bacteria (including total coliform, E. coli, fecal streptococcus, and fecal coliform). Media used for $E$. coli analyses included NA-MUG (U.S. Environmental Protection Agency, 1991) for the Lower Susquehanna, and modified mTEC (U.S. Environmental Protection Agency, 2002) for the Delaware and the Tennessee River basins. E. coli concentrations from all three river basins were analyzed

Table 7. General land-use designation guidelines for wells and springs in the Valley and Ridge aquifers.

[>, greater than; $<$, less than]

\begin{tabular}{lcc}
\hline \multirow{2}{*}{$\begin{array}{c}\text { General } \\
\text { land-use } \\
\text { designation }\end{array}$} & \multicolumn{2}{c}{$\begin{array}{c}\text { Land use in 1,640-foot radius } \\
\text { around well or spring }\end{array}$} \\
\cline { 2 - 3 } & Agricultural land-use & Urban land-use \\
\hline Agricultural & $>50$ percent & $<10$ percent \\
Urban & $<25$ percent & $>25$ percent \\
Undeveloped & $<25$ percent & $<5$ percent \\
Mixed & \multicolumn{2}{c}{ All not meeting above definitions } \\
\hline
\end{tabular}


together. Analytical methods varied in the use of maximum reporting levels. The data from the Lower Susquehanna River basin were analyzed using a 100-milliliter $(\mathrm{mL})$ sample and a plate count that resulted in "too numerous to count" designations for counts greater than 80 colonies per $100 \mathrm{~mL}$. The Tennessee River basin samples were analyzed using a method of multiple dilutions so that bacteria counts greater than 80 were possible. For consistent comparison purposes, statistical analysis was conducted using a consistent maximum concentration of 80 colonies per $100 \mathrm{~mL}$. A minimum reporting limit of 1 colony per $100 \mathrm{~mL}$ was common to all of the analyses.

Samples collected prior to 1996 (95 samples) were analyzed for 60 VOCs using a laboratory reporting level of 0.2 microgram per liter $(\mu \mathrm{g} / \mathrm{L})$. After 1996, the number of VOC analytes for the remaining 95 samples was increased to 87 , and low-level analytical methods were adopted, generally reducing detection levels depending upon the compound, with laboratory reporting levels ranging from 0.018 to $3.4 \mu \mathrm{g} / \mathrm{L}$.

\section{Quality-Assurance Methods}

Three types of quality-assurance samples (blanks, spikes, and replicates) were collected as routine elements of NAWQA groundwater-quality studies in the Valley and Ridge aquifers. These included 26 nutrient field blanks, 28 pesticide field blanks, 30 major ion field blanks, 18 VOC field blanks, 9 pesticide replicates, 21 nutrient replicates, 8 VOC replicates, 15 VOC spikes, 9 VOC spiked replicates, 20 pesticide spikes, and 3 pesticide spiked replicates. Detection rates and spike recoveries were similar to those reported by Lindsey and others (2009) and Martin (1999, 2001), and confirmed that process contamination of environmental samples was minimal and acceptable for the purposes of this study (Martin and others, 1998).

\section{Human-Health Benchmarks}

Human-health benchmarks were used to assess the potential safety of drinking water and are defined in this study as either the U.S. Environmental Protection Agency (USEPA) drinking-water maximum contaminant level (MCL) or the health-based screening level (HBSL) for compounds without MCLs. MCLs are enforceable standards that refer to the highest level of a contaminant that is allowed in public drinkingwater systems (U.S. Environmental Protection Agency, 2006). HBSLs are non-enforceable levels that were developed by the USGS in collaboration with the USEPA and other organizations (Toccalino and others, 2008). The HBSL for a noncarcinogenic compound is the maximum concentration in drinking water that is not expected to cause any adverse effects from chronic exposure over a lifetime (Toccalino and others, 2008). HBSLs for carcinogenic compounds are established as higherand lower-level HBSLs, which correspond to concentrations of a compound in drinking water that increase estimated lifetime cancer risk by one chance in 10,000 (the higher HBSL) and one chance in 1 million (lower HBSL).

\section{Statistical Methods}

Four nonparametric statistical tests were used to evaluate the significance of relations and differences among waterquality sample data and descriptive characteristics. Two of these, the Spearman's rank correlation coefficient (rho) (Helsel and Hirsch, 2002) and a censored Kendall's tau (Helsel, 2005) were used to test for significance in relations among variables. The other two statistical tests, the Kruskal-Wallis (Helsel and Hirsch, 2002) and Tukey's multiple-comparison test (MCT), were used to test for the significance of differences among multiple groups. Spearman's rho is a monotonic correlation test in which a positive value of rho indicates that the response variable $(Y)$ increases as the explanatory variable $(X)$ increases. Higher values of Spearman's rho indicate a stronger monotonic correlation. Kendall's tau is a test of concordance (changing in the same direction) among pairs of observations. The censored Kendall's tau is a modified approach to better handle multiple detection limits. The Kruskal-Wallis test was used to identify the presence of significant differences in medians among three or more groups. When the Kruskal-Wallis test indicated the presence of statistically significant differences among groups (alpha $=0.05$ ), a Tukey's multiple-comparison test (MCT) was used to identify groupings within significance categories. All of these nonparametric tests were performed on rank-transformed datasets. In assigning ranks, non-detects were ranked lower than the lowest value detected or estimated, following the methodology of Gilliom and others (2006). All other measured concentrations and estimates were ranked according to their nominal values.

\section{Geographic Information System Methods and Topographic Variables}

A series of geographic variables was computed for each well or spring to establish its position in relation to principal topographic features (table 8). These included (a) the distance to the nearest topographic divide (ridgeline), (b) the distance to the nearest major downgradient stream, and (c) the distance to the nearest mapped stream of any magnitude. In addition, "a" and "b" were summed to produce a measure of (d) the distance from the topographic divide to the nearest major downgradient stream, which was then divided into "a" to produce an estimate of (e) the relative distance of each well or spring along the slope of an inferred hydraulic gradient from ridge to valley (fig. 4). This computed geographic term (e) has been described elsewhere as the normalized lateral position (Landon and others, 2010), and that term is used in this report. The normalized lateral position (NLP) is interpreted such that a value near 0.0 places a point near a local high (ridge) and a value near 1.0 places a point near a local low (stream). 
Table 8. Description of topographic variables derived using geographic information system methods.

\begin{tabular}{|c|c|c|}
\hline Variable name & Description & Source or method \\
\hline $\begin{array}{l}\text { Distance to nearest } \\
\text { topographic divide }\end{array}$ & $\begin{array}{l}\text { Distance from sampling point to nearest upgradient } \\
\text { topographic divide (ridge), in meters }\end{array}$ & $\begin{array}{l}\text { U.S. Department of Agriculture, Natural Resources } \\
\text { Conservation Service, } 1999 \\
\text { U.S. Geological Survey, } 2002\end{array}$ \\
\hline $\begin{array}{l}\text { Distance to nearest major } \\
\text { stream }\end{array}$ & $\begin{array}{l}\text { Distance from sampling point to nearest downgradient } \\
\text { major stream, in meters }\end{array}$ & Falcone, 2003 \\
\hline $\begin{array}{l}\text { Distance to nearest mapped } \\
\text { stream }\end{array}$ & $\begin{array}{l}\text { Distance from sampling point to nearest mapped stream } \\
\text { of any magnitude, in meters }\end{array}$ & Falcone, 2003 \\
\hline $\begin{array}{l}\text { Distance from topographic } \\
\text { divide to major stream }\end{array}$ & $\begin{array}{l}\text { Distance from topographic divide to nearest } \\
\text { downgradient major stream measured through } \\
\text { sampling point, in meters }\end{array}$ & $\begin{array}{l}\text { Distance to nearest topographic divide divided by } \\
\text { distance to nearest major stream }\end{array}$ \\
\hline Normalized lateral position & $\begin{array}{l}\text { Relative location of sampling point between } \\
\text { topographic divide and nearest major stream, as a } \\
\text { decimal fraction }\end{array}$ & $\begin{array}{l}\text { Distance to topographic divide divided by the } \\
\text { distance from topographic divide to major stream }\end{array}$ \\
\hline Stream density & $\begin{array}{l}\text { Density of stream network in meters of stream per } \\
\text { square meter of land surface }\end{array}$ & Falcone, 2003 \\
\hline
\end{tabular}

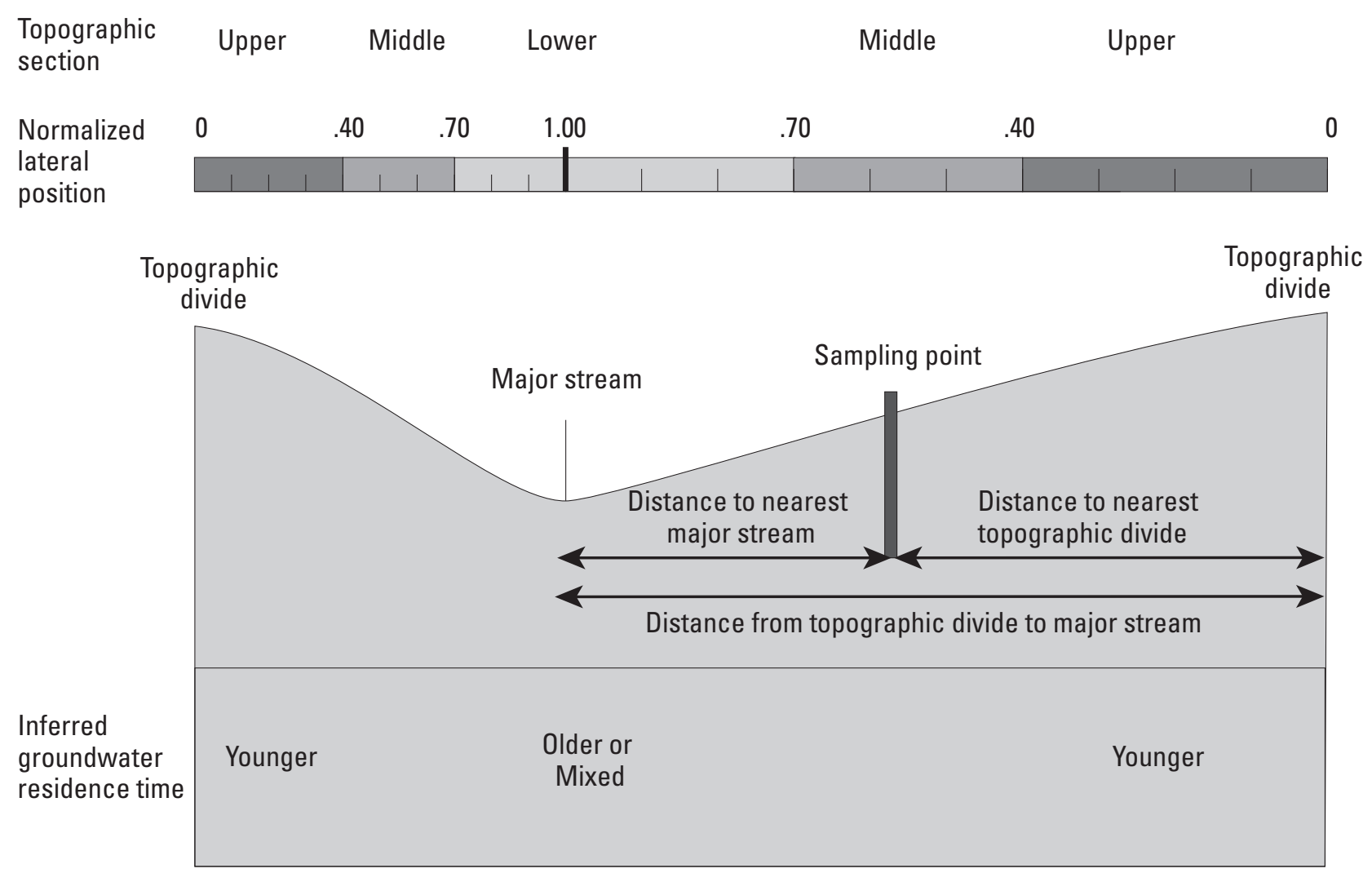

Figure 4. Locations of topographic variables, normalized lateral position variables, and topographic sections. 
Principal topographic features (ridges and streams) were determined from available digital geospatial datasets. Topographic divides were defined where possible using 12-digit hydrologic unit code (HUC12) drainage basin boundaries (U.S. Department of Agriculture, Natural Resources Conservation Service, 1999). Where HUC12 topographic divides did not represent basin boundaries of sub-watersheds, ridgelines were manually digitized from hill shades using digital elevation models (DEMs) from the Shuttle Radar Topography Mission Elevation Dataset (U.S. Geological Survey, 2002). Streams were mapped using the USGS National Hydrography Dataset (NHD) at the 1:100,000 scale (Falcone, 2003).
Distances to topographic features were computed using automated geographic information system (GIS) tools. A proximity analysis identified the shortest separation between each well and spring and a corresponding topographic divide or stream (fig. 5). All distances were checked to verify that selected topographic features reflected realistic local flow paths (for example, ensuring that the "nearest stream" was not separated from a given well by a topographic divide), and corrections were made manually where necessary. Distances from springs to streams were assumed to be $0 \mathrm{ft}$.

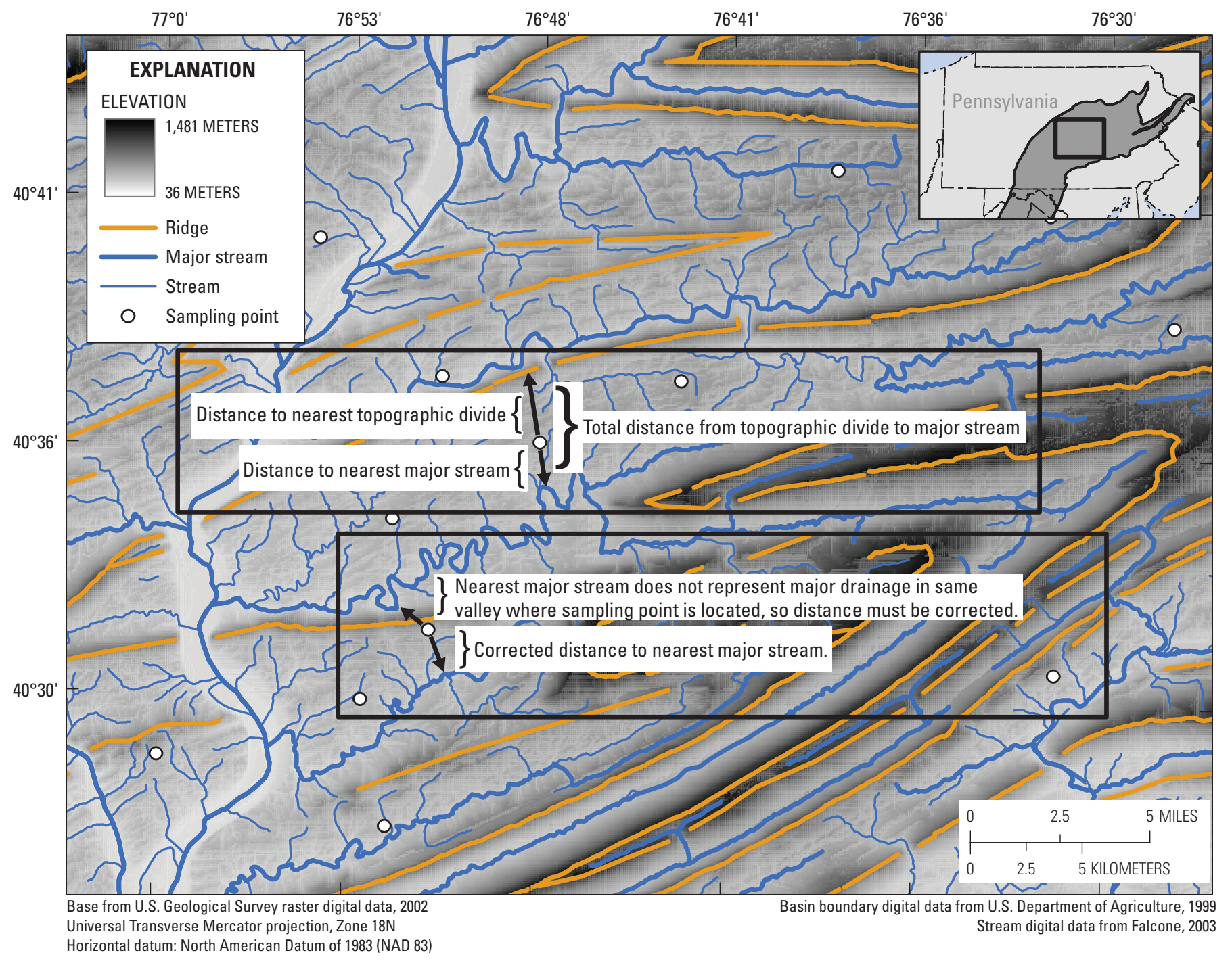

Figure 5. Examples of calculating distance to nearest topographic divide and distance to nearest major stream in central Pennsylvania. 


\section{Groundwater Quality in the Valley and Ridge Aquifers}

Groundwater quality in the Valley and Ridge aquifers is influenced by natural and anthropogenic factors. Natural factors, such as topographic position and mineral composition of underlying geology, act to produce basic physical and geochemical conditions in groundwater that are reflected in physical properties, such as $\mathrm{pH}$, temperature, specific conductance, and alkalinity, and in chemical concentrations of dissolved oxygen, radon, and major mineral ions. Anthropogenic factors, such as land use and surface contamination, can contribute nutrients, pesticides, pesticide degradation products, dissolved organic carbon (DOC), VOCs, and fecal-indicator bacteria to groundwater. Although natural and anthropogenic factors may affect water use and availability independently, they also interact. Chemical properties, for example, can influence the fate and transport of contaminants. Land use can influence recharge and soil properties, and recharge can influence residence time, dissolved oxygen, and $\mathrm{pH}$.

\section{Basic Groundwater Properties and Chemical Composition}

With a few exceptions, specific conductance, dissolved oxygen, alkalinity, and total dissolved solids were greater in water from sites in networks in carbonate-rock aquifers than in siliciclastic-rock aquifers (fig. 6). Samples from sites in the Tennessee basin networks (TCS and TCM) had distinctly lower specific conductance, alkalinity, and dissolved solids concentrations than samples from other networks in carbonaterock aquifers and appeared to more closely resemble the Potomac basin siliciclastic-rock agricultural network (PSA), which had somewhat higher concentrations for the same properties and constituents than other networks in siliciclasticrock aquifers. Median $\mathrm{pH}$ concentrations were about the same (between 7.0 and 7.3) for all networks without regard to geology, but the range of $\mathrm{pH}$ was greater in water from networks in the less-buffered siliciclastic-rock aquifers.

The major ion chemistry of groundwater in the Valley and Ridge aquifers reflected geologic controls similar to those influencing physical properties. Values for specific conductance, alkalinity, and total dissolved solids and concentrations of calcium and magnesium are higher in samples from carbonate-rock aquifers than in samples from siliciclastic-rock aquifers (fig. 7). The dissolution of limestone and dolomite in the carbonate-rock aquifers probably is the cause of these higher values and concentrations. Calcite saturation tended to be least where (1) pH variability was greatest, (2) iron, sulfate, and manganese concentrations were greatest, and (3) dissolved oxygen was least (PSA network). As a rule, iron, manganese, and sulfate are largely insoluble in the presence of oxygen, and are likely to be in solution only when dissolved oxygen concentrations are less than $1 \mathrm{mg} / \mathrm{L}$. Water from carbonaterock aquifers generally is well oxygenated (McMahon and Chapelle, 2008).

Non-enforceable guidelines for secondary maximum contaminant levels (SMCLs) have been established for some constituents for aesthetic considerations (taste, color, cosmetic effects, corrosivity, or staining) for public water-supply systems (U.S. Environmental Protection Agency, 1992). Six percent of samples from carbonate-rock aquifers and 46 percent of samples from siliciclastic-rock aquifers exceeded the SMCL for manganese $(50 \mu \mathrm{g} / \mathrm{L})$. Iron concentrations exceeded the SMCL $(300 \mathrm{mg} / \mathrm{L})$ in 1.7 percent of samples from carbonate-rock aquifers and in 27 percent of samples from siliciclastic-rock aquifers (fig. 7). Two SMCLs represent a desirable range for $\mathrm{pH}$; $\mathrm{pH}$ values were lower than desired in 24 percent of samples from siliciclastic-rock aquifers (fig. 6). Total dissolved solids exceeded the SMCL of $500 \mathrm{mg} / \mathrm{L}$ in one sample from siliciclastic-rock aquifers and in 10 samples from carbonate-rock aquifers (fig. 6). No samples exceeded the SMCL of $250 \mathrm{mg} / \mathrm{L}$ for sulfate or chloride, nor did any samples exceed the SMCL of $2 \mathrm{mg} / \mathrm{L}$ for fluoride.

In general, major ion concentrations in samples from carbonate-rock aquifers showed significant differences when grouped by lithology (dolomite, limestone, or dolomite and limestone; fig. 8), notably including higher concentrations of sodium, calcium, sulfate, and chloride in the limestone-anddolomite rock type than in other carbonate lithologies. Sodium and chloride occur naturally through mineral weathering, and their concentrations can increase with groundwater age. Both, however, can also be related to anthropogenic sources (road salts and disinfectants). Chloride concentrations were well correlated to sodium ( $\mathrm{p}=<0.0001$, Spearman's $r h o=0.62$ ), and both were highest in samples from the northern urban network (SCU) and least in the southern networks (TCM and TCS) where road salt is used less often. No significant patterns were apparent for magnesium when summarized by lithology. Given differential rates of dissolution of dolomite and calcite, higher concentrations of magnesium might have been expected where groundwater is older. If the ages of water are similar, then the sources of sodium and chloride are likely to be anthropogenic. The fact that rock type was generally unimportant in describing major ions in water samples from siliciclastic-rock aquifers may relate to the lower solubility of minerals in sandstones (mostly silicates) but may also reflect the age of the water and its relative topographic position. 

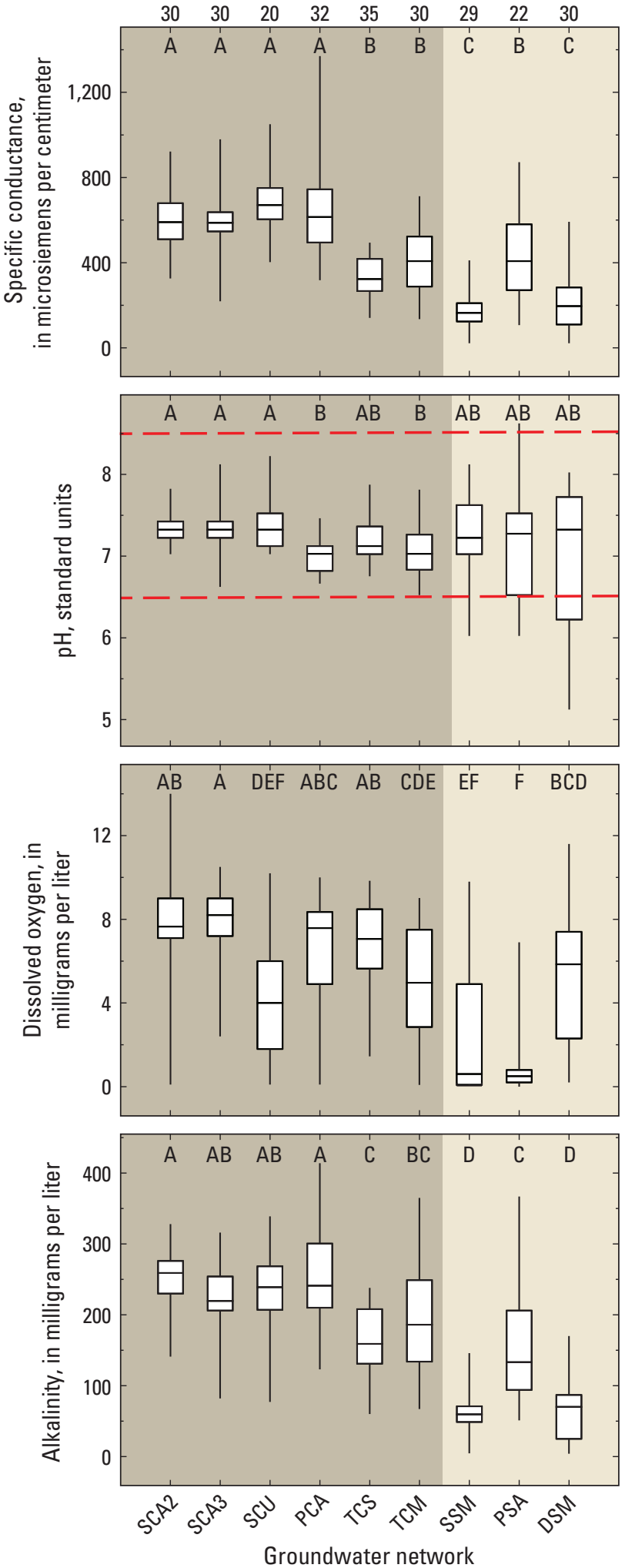

\section{EXPLANATION}

30 Number of samples

A Statistical group from nonparametric Tukey's test

Maximum value

75th percentile

Median

25th percentile

Minimum value

Carbonate-rock aquifers

Siliciclastic-rock aquifers

- Secondary maximum contaminant level for $\mathrm{pH}$, above 8.5 and below 6.5 ;

for total dissolved solids, above 500 milligrams per liter

DSM Groundwater network code,

see table 3 for network abbreviation codes

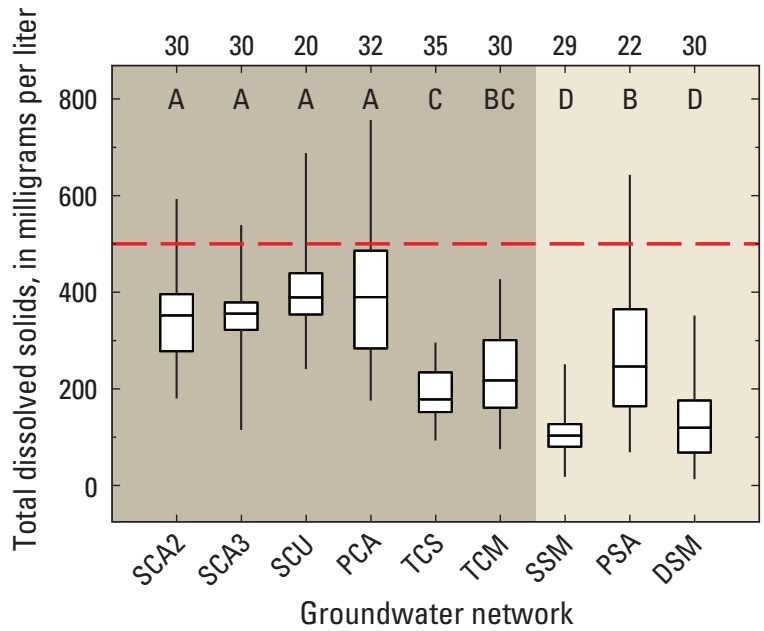

Figure 6. Specific conductance, $\mathrm{pH}$, dissolved oxygen, total dissolved solids, and alkalinity for water samples from networks in the Valley and Ridge aquifers, 1993-2002. 

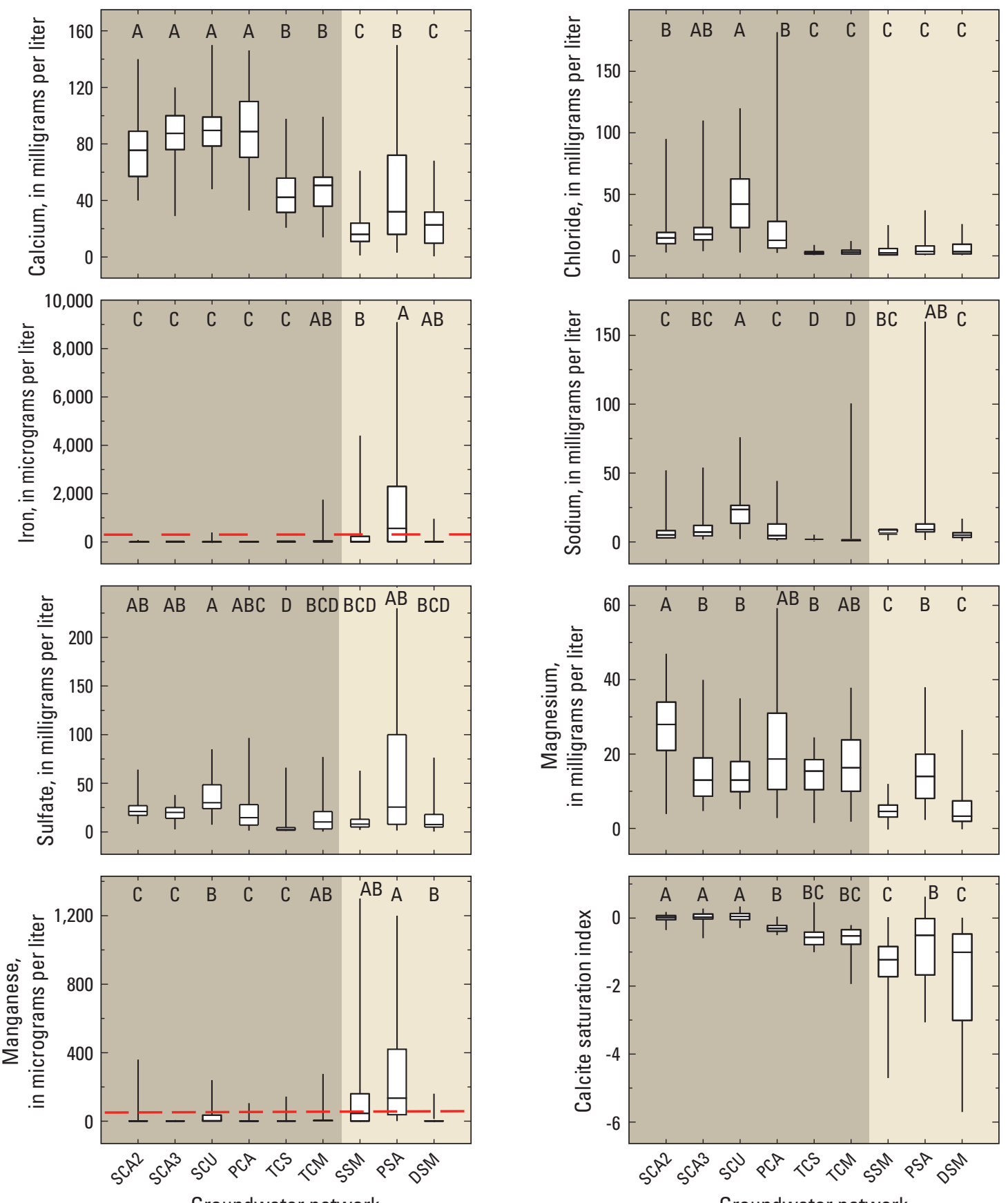

Groundwater network

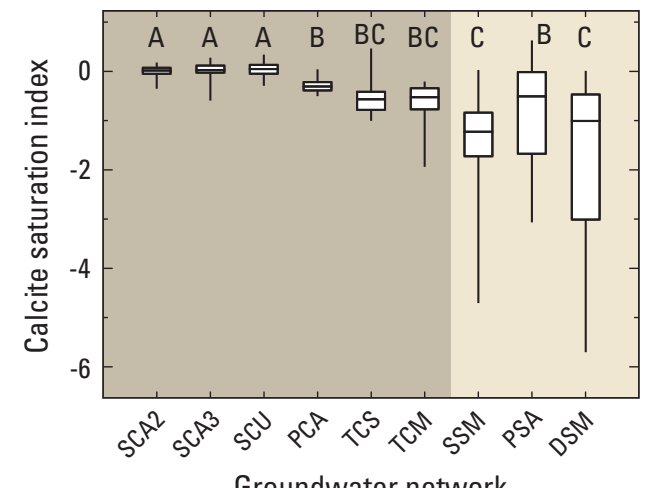

\section{EXPLANATION}

A Statistical group from nonparametric Tukey's test

Maximum value

75th percentile

Median

25th percentile

Minimum value
Carbonate-rock

aquifers

Siliciclastic-rock aquifers

Secondary maximum contaminant level

for iron, equals 300 micrograms per liter;

for manganese, equals 50 micrograms per liter
DSM Groundwater network code, see table 3 for network abbreviation codes

Figure 7. Concentrations of constituents and calcite saturation index values for groundwater samples from networks in the Valley and Ridge aquifers, 1993-2002. 

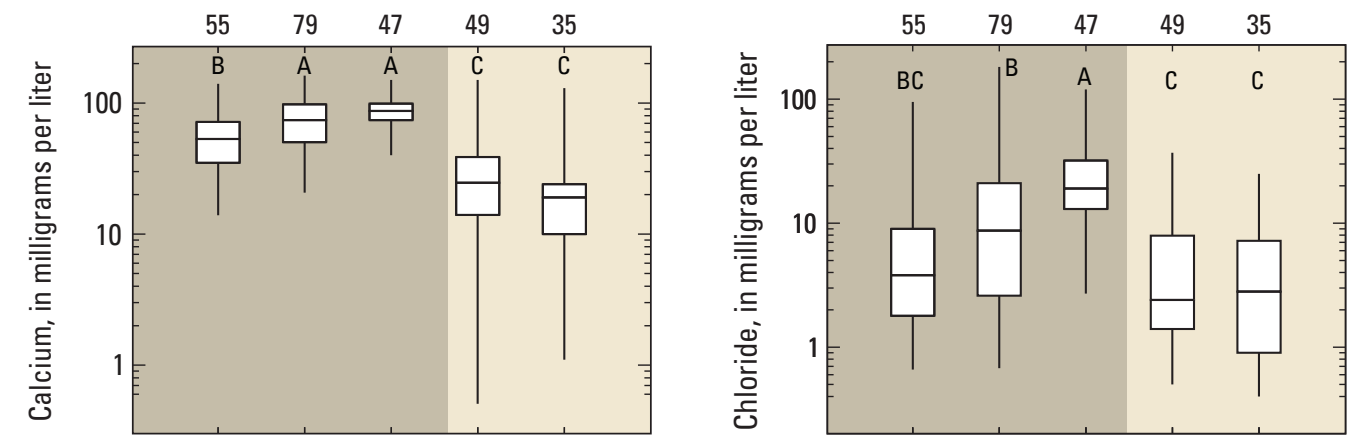

\section{EXPLANATION}

55 Number of samples

A Statistical group from nonparametric Tukey's test

Maximum value

75th percentile

Median

25th percentile

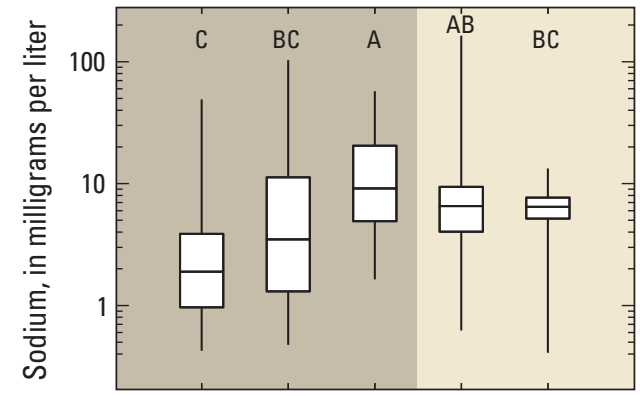

Minimum value

Carbonate-rock aquifers

Siliciclastic-rock aquifers

Secondary maximum contaminant level for iron, equals 300 micrograms per liter;

for manganese, equals 50 micrograms per liter
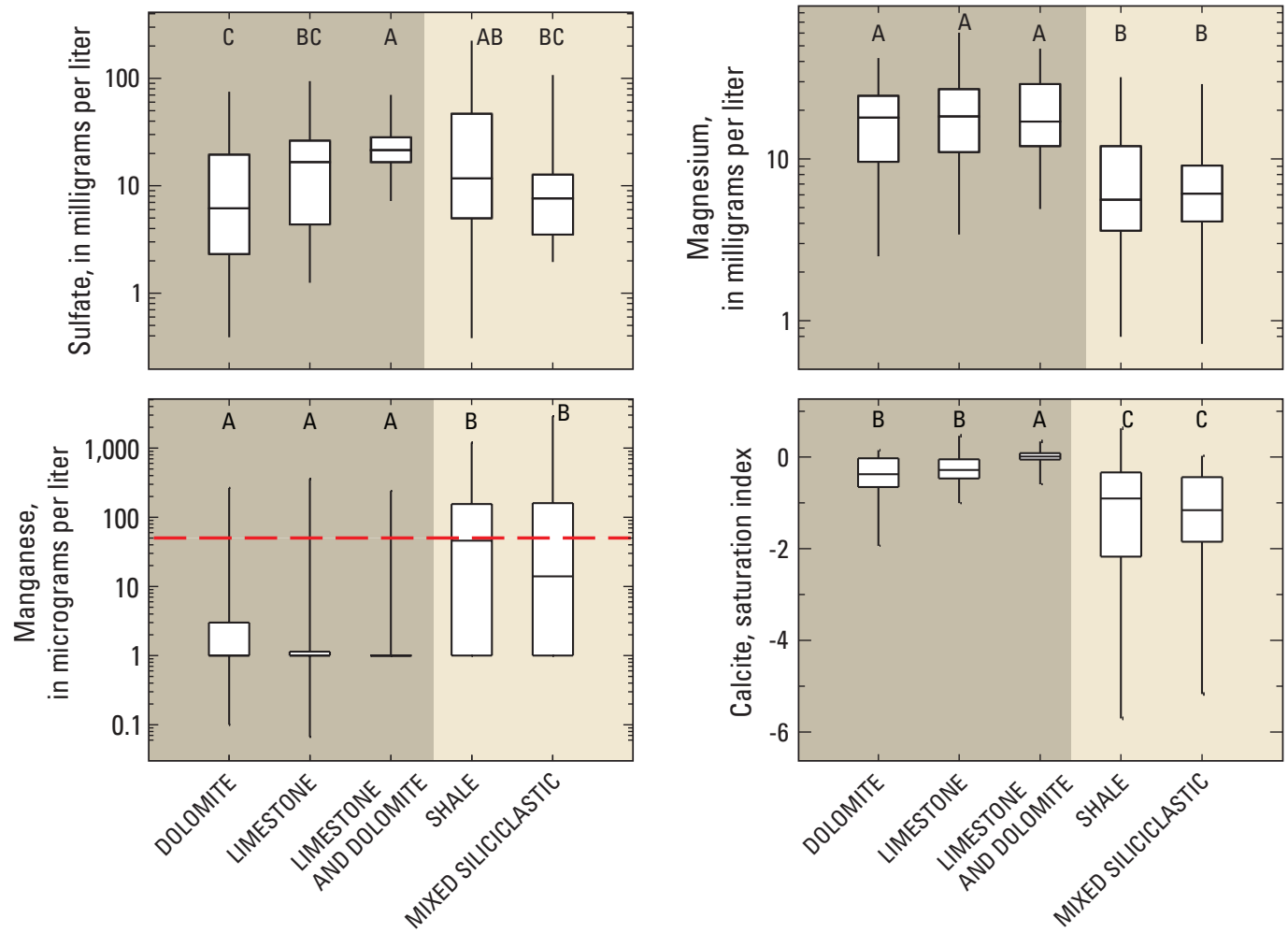

Figure 8. Concentrations of constituents by lithologic group for groundwater samples from the Valley and Ridge aquifers, $1993-2002$. 


\section{Residence Time, Oxygen, and Chemical Equilibria}

The age of water in the various aquifers of the Valley and Ridge is an important determinant of groundwater quality. In combination with factors such as reaction rates, groundwater residence time determines oxidation state, which in turn influences concentrations of dissolved metals, controls denitrification, and moderates processes of biodegradation and natural attenuation of organic contaminants. Concentrations of oxygen in groundwater are generally the result of two timedependent processes: the introduction of oxygen from aerated surface waters and the removal of free oxygen by oxidation of minerals and organic compounds. The introduction of oxygen is largely controlled by climatic and environmental factors that determine recharge rates. The removal of free dissolved oxygen may be controlled by geochemical reaction rates, but in most cases is moderated by bacterial alteration of minerals and organic compounds. Bacteria harvest energy in groundwater by transforming chemical compounds through successive states of oxidation, reducing one compound to oxidize another, each reaction yielding energy for metabolic use. Those chemical reactions that yield the most energy at any point in time are generally favored such that specific oxidation states follow somewhat predictable orders of transformation. In general, the order of metabolic efficiency among successive oxidizing agents is as follows: oxygen, nitrate, manganese, ferric iron, sulfate, and carbon dioxide. This order is referred to as the ecological succession of terminal electron-accepting processes (McMahon and Chapelle, 2008). As a result, the relative concentrations of constituents in varying states of oxidation may be an indication of the sources and age of groundwater.

Although most of the sample analyses presented in this report did not include measurements of groundwater age, recent studies by the USGS and others have addressed groundwater age and the relation of age to oxygen in carbonate- and siliciclastic-rock aquifers of the Valley and Ridge (Lindsey and others, 2003; Nelms and others, 2003; McCoy and Kozar, 2007; Hinkle and others, 2010). Although the overall ranges of measured residence times ( $0-48$ years) and median residence times (about 15 years) were similar for the two aquifer types, the distributions were clearly different at the older ages, with samples from about 8 percent of wells in carbonate-rock aquifers exceeding a 25 -year residence time, but with samples from about 28 percent of wells in siliciclastic-rock aquifers exceeding the same residence time (fig. 9). These studies also found that groundwater residence time was positively correlated with silica concentration, magnesium-to-calcium ratios (for the carbonate-rock aquifers), and sodium concentrations (for siliciclastic-rock aquifers), and was negatively correlated with dissolved oxygen.

Overall, total dissolved solids, specific conductance, and alkalinity tend to increase with time and may provide a relative measure of residence time. Recharge water initially is dilute. As water resides in the ground, concentrations of dissolved solutes tend to increase at rates that vary with mineral concentration and environmental conditions. In carbonate-rock aquifers, water can reach saturation with respect to calcite in a matter of days (White, 1988), so it is not surprising that the calcite saturation indices (SI) for the carbonate-rock aquifers in the Valley and Ridge were generally near zero. The rate of dissolution of dolomite is slower than that of calcite, so the dolomite SI or magnesium-calcium molar ratios can provide an indication of residence time in the carbonate-rock aquifers (Musgrove and Banner, 2004). Similarly, strontium/calcium ratios have been used as indicators of groundwater residence time, with greater strontium indicating older water (Musgrove and Banner, 2004). Within siliciclastic-rock aquifers, where calcite is less abundant, the SI for calcium also may provide some indication of residence time. Lindsey and others (2003) demonstrated a positive relation of sodium to age in siliciclastic-rock aquifers.

Several possible indicators of residence time in the Valley and Ridge aquifers were tested for correlation to groundwater age using the dataset summarized in figure 9. Sites were classified into one of three reduction-oxidation (redox) states (oxic, anoxic, or mixed) based on concentrations of dissolved oxygen, manganese, and iron (McMahon and Chapelle, 2008) using criteria detailed in table 9. Manganese and iron were preferred among other constituents because their presence in water is sensitive to anoxic conditions in otherwise oxic systems. In general, these tests indicated a prevalence of mixed oxic-anoxic conditions, as supported by the finding of elevated dissolved iron and dissolved oxygen in the same samples.

Mixed oxic-anoxic samples indicate complex flow systems in which multiple sources of water mix during sample extraction.

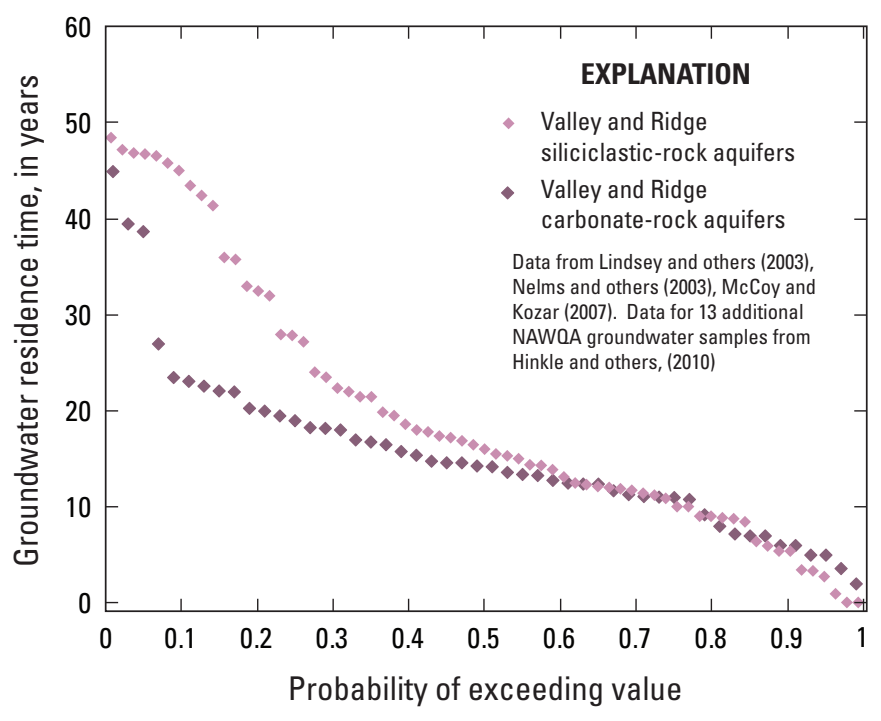

Figure 9. Groundwater residence time distribution in the Valley and Ridge carbonate- and siliciclastic-rock aquifers. 
Table 9. Threshold concentrations for identifying oxidationreduction designation.

[ $\geq$, greater than or equal to; <, less than; N/A, no threshold identified]

\begin{tabular}{cccc}
\hline \multirow{2}{*}{$\begin{array}{c}\text { Oxidation- } \\
\text { reduction } \\
\text { designation }\end{array}$} & \multicolumn{3}{c}{$\begin{array}{c}\text { Water-quality criteria' } \\
\text { (milligrams per liter) }\end{array}$} \\
\cline { 2 - 4 } & $\begin{array}{c}\text { Dissolved } \\
\text { oxygen }\end{array}$ & Manganese & Iron \\
\hline Oxic & $\geq 0.5$ & $<0.05$ & $<0.1$ \\
Mixed & $\geq 0.5$ & $\geq 0.05$ & $\geq 0.1$ \\
Anoxic & $<0.5$ & N/A & N/A \\
\hline
\end{tabular}

'McMahon and Chapelle (2008).

Overall, groundwater residence time was negatively correlated to dissolved oxygen concentrations in both aquifer types (table 10), and the progression with age from oxic to anoxic or to mixed conditions appears faster in the siliciclastic-rock aquifers than in the carbonate-rock aquifers based on differences in the proportions of anoxic and mixed conditions in relatively young water (residence time of less than 20 years) in the two aquifer types. Anoxic or mixed conditions were more prevalent in both aquifer types in groundwater that was generally older (fig. 10). However, relatively few samples from carbonate-rock aquifers had residence times greater than 20 years. A substantially greater number of sites in siliciclastic-rock aquifers produced water with residence times greater than 20 years.

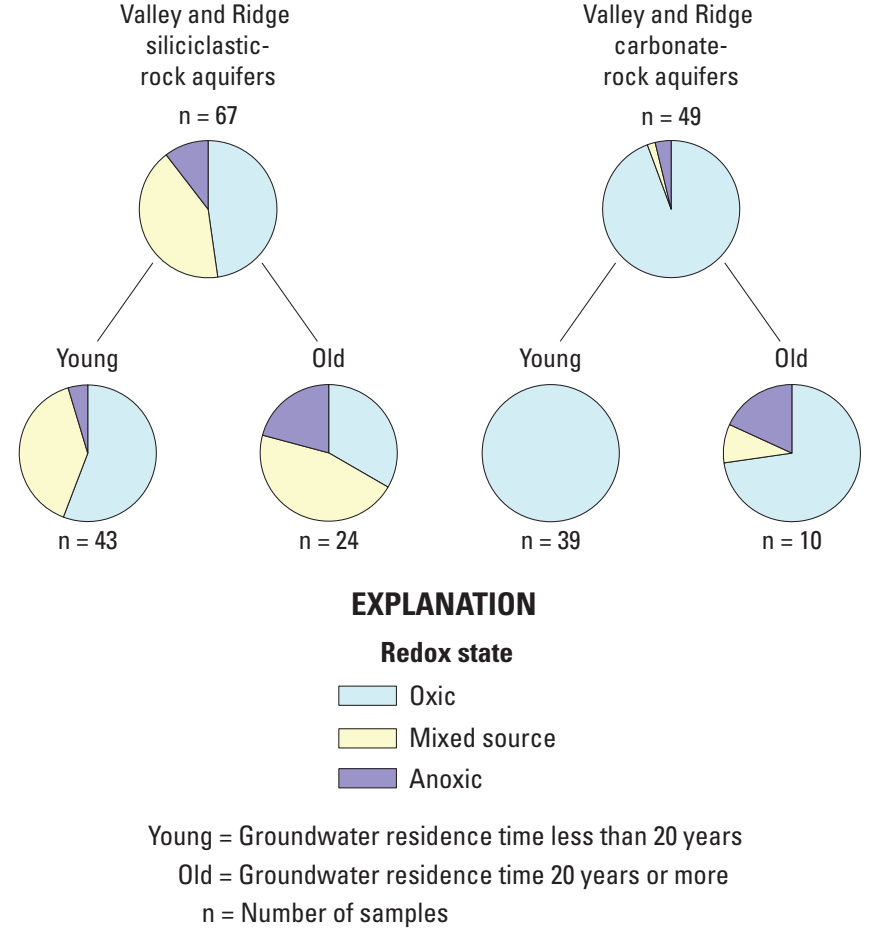

Data from Lindsey and others (2003), Nelms and others (2003), McCoy and Kozar (2007). Data for 13 additional NAWQA groundwater samples from Hinkle and others (2010)

Figure 10. Dominant redox processes by aquifer type and groundwater age.

Table 10. Spearman's rho correlations between groundwater age and well construction or water chemistry.

[rho shown for variables statistically correlated at the 95-percent confidence level; NS, not statistically significant; $\mathrm{n}$, number of observations].

\begin{tabular}{lccc}
\hline \multirow{2}{*}{ Variable } & \multicolumn{3}{c}{ Groundwater age $^{\mathbf{1}}$} \\
\cline { 2 - 4 } & All & Carbonate $^{\prime}$ & Siliciclastic \\
\hline Well depth & $\mathrm{NS}$ & $\begin{array}{c}0.44 \\
(\mathrm{n}=31)\end{array}$ & NS \\
Dissolved oxygen concentration & $\begin{array}{c}-0.52 \\
(\mathrm{n}=117)\end{array}$ & $\begin{array}{c}-0.44 \\
(\mathrm{n}=31)\end{array}$ & $\begin{array}{c}-0.54 \\
(\mathrm{n}=67)\end{array}$ \\
Sodium & $\begin{array}{c}0.27 \\
(\mathrm{n}=64)\end{array}$ & $\begin{array}{c}0.45 \\
(\mathrm{n}=34)\end{array}$ & $\mathrm{NS}$ \\
Magnesium/ calcium ratio & $\begin{array}{c}0.34 \\
(\mathrm{n}=34)\end{array}$ & $\begin{array}{c}0.48 \\
(\mathrm{n}=34)\end{array}$ & $\mathrm{NS}$ \\
Silica & $\begin{array}{c}0.47 \\
(\mathrm{n}=40)\end{array}$ & $\mathrm{NS}$ & $\begin{array}{c}0.47 \\
(\mathrm{n}=21)\end{array}$ \\
\hline
\end{tabular}

${ }^{1}$ Data from Lindsey and others, 2003, Nelms and others, 2003, McCoy and Kozar, 2007. Data for 13 additional NAWQA groundwater samples from Hinkle and others, 2010. 


\section{Water Quality in Relation to Land Use and Topography}

In the Valley and Ridge aquifers, topography and land use commonly are related. Steep slopes near the tops of ridges are typically forested, whereas valleys are generally more agricultural or urban, and discharge areas and streams attract development (fig. 11). Thus, location may determine both the quality of source water and residence times for groundwater.

Water-quality characteristics associated with groundwater residence time (dissolved oxygen, specific conductance, $\mathrm{pH}$, and redox state) were compared to measures of relative topographic position (NLP) and aquifer type for the 230 network wells (springs excluded). When NLP is grouped into three topographic sections (upper $=0.0-0.39$, middle $=0.4-0.7$, and lower $=0.71-1.0)$, specific conductance values are slightly lower in samples from sites in the upper topographic sections when compared with samples from the lower topographic sections in both carbonate- and siliciclastic-rock aquifers; $\mathrm{pH}$ also appears to be slightly lower in samples from the upper topographic sections when compared with the samples from lower topographic sections in the siliciclastic-rock aquifers (fig. 12). These observations are consistent with the notion of water aging as it moves downgradient and with the results of Yager and others (2009), which related differences in the age of water to topographic section (fig. 13). None of these patterns, however, were statistically significant, perhaps reflecting localized variations in land use and lithology or limitations of the NLP as an explanatory tool when applied to the hydrology of the Valley and Ridge aquifers.

Redox states, when viewed by topographic section, fail to show obvious patterns in carbonate-rock aquifers (fig. 14) though there may be some trend in the presence of anoxic conditions with increasing NLP in siliciclastic-rock aquifers (fig. 15). These results may be confounded by the distribution of land use among topographic sections and the distribution of wells within sections. In general, the distribution of sampled wells among the three topographic sections was remarkably similar in the two aquifer types. In the carbonate- and siliciclastic-rock aquifers, about 50 percent of wells were located in the lower 30 percent of slopes, and only 18 percent of wells were located in the upper 40 percent of slopes.

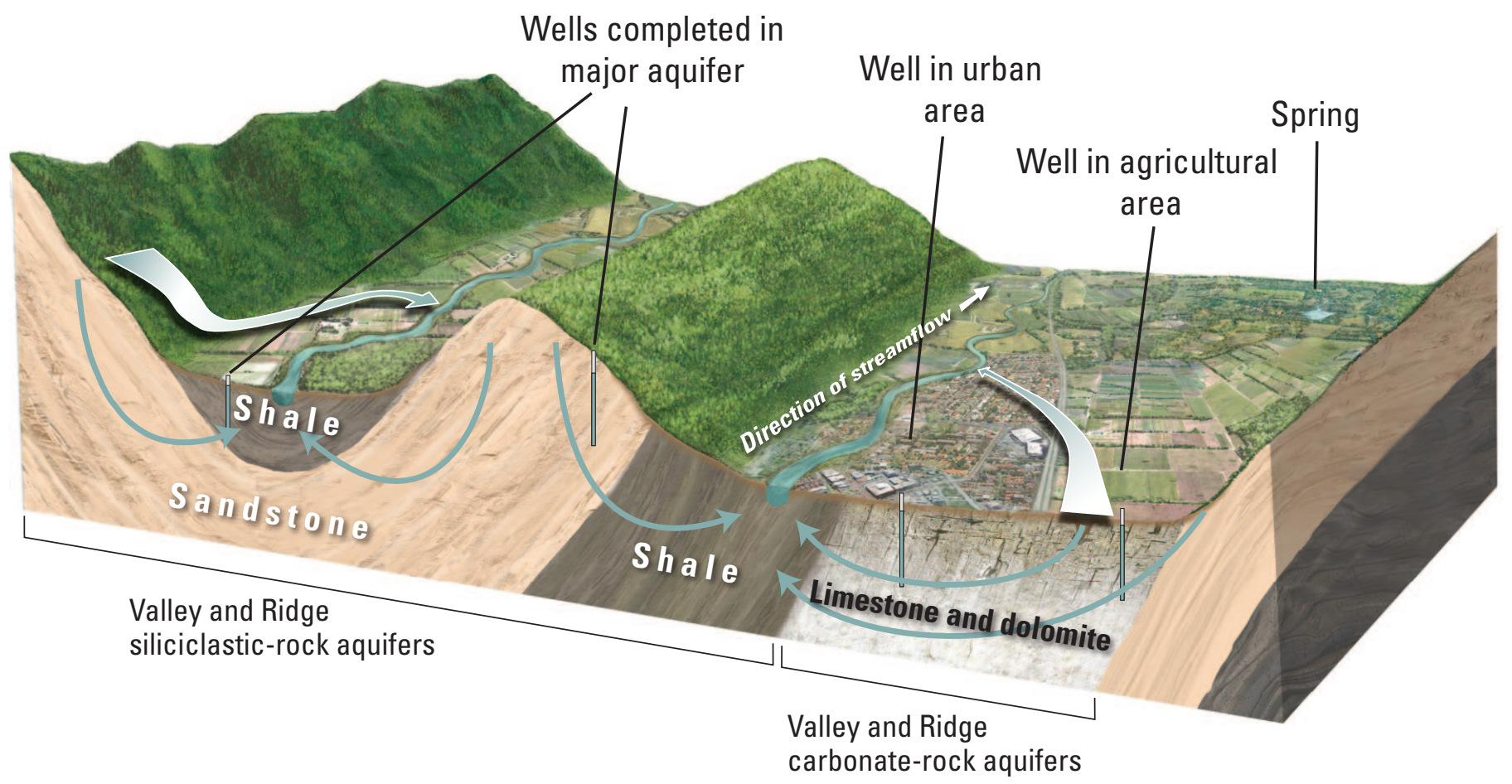

\section{EXPLANATION}

Hypothetical groundwater flow path in cross-section view

Hypothetical groundwater flow path in map view

Figure 11. Distribution of land use with respect to topography and aquifer type in the Valley and Ridge. 

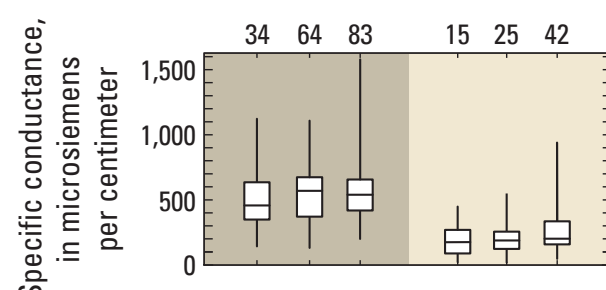

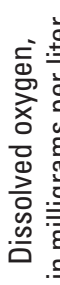

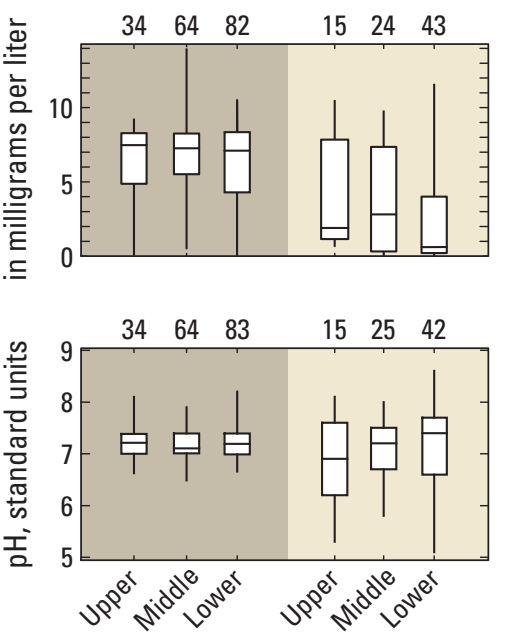

Topographic section

Figure 12. Distribution of specific conductance, dissolved oxygen concentrations, and $\mathrm{pH}$ by topographic section and aquifer type, for the Valley and Ridge aquifers, 1993-2002.
Overall, few statistically significant correlations were apparent between NLP and geochemical indicators of residence time in samples from sites in carbonate-rock aquifers. No significant correlations were apparent in comparisons of the dataset as a whole. Analyses of the correlation of NLP to various geochemical measures within subsets of the data showed several significant positive correlations in samples within specific topographic sections of carbonate-rock aquifers - particularly involving calcium and strontium in the upper topographic section (table 11). A negative correlation between NLP and dissolved oxygen in the middle and lower topographic sections was consistent with the expectation of decreasing oxygen with residence time, but the absence of anoxic conditions in the middle section may suggest a deeper, indirect flow path (fig. 14). The absence of calcium correlations within lower topographic sections may reflect groundwater already being near saturation with respect to calcite as it moves downgradient. Although these results are hardly definitive, they support a basic conceptual model in which topography provides one of several controls on the age and chemistry of groundwater.

Geochemical changes along the NLP also were evident in the samples from sites in siliciclastic-rock aquifers where correlation analysis showed significant, though relatively weak, positive correlations between NLP and calcite SI, dolomite SI, sodium concentration, magnesium concentration, and specific conductance in samples for the set of wells spanning all topographic sections (table 12). Comparisons within specific topographic sections produced results that were no better than those for carbonate-rock aquifers but which were notably different in that the majority of significant correlations in samples were confined to the lower topographic section. Only sodium had a significant increase in concentration with NLP in samples in the upper topographic section. One point of

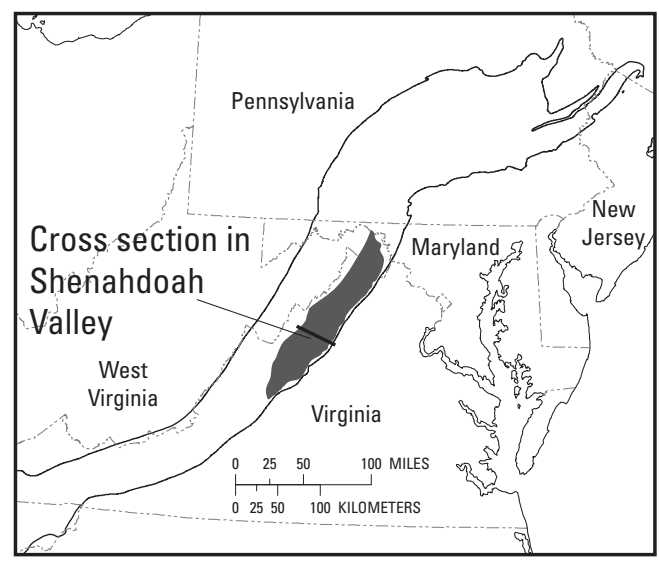

Topographic section

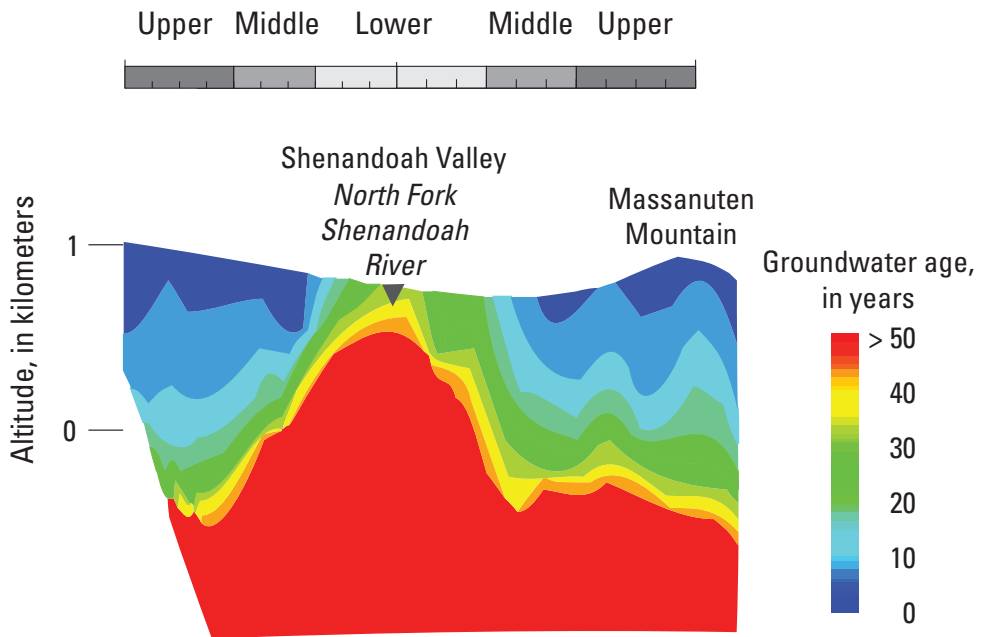

Figure 13. Cross section of Shenandoah Valley illustrating distribution of groundwater residence time (from Yager and others, 2009). 

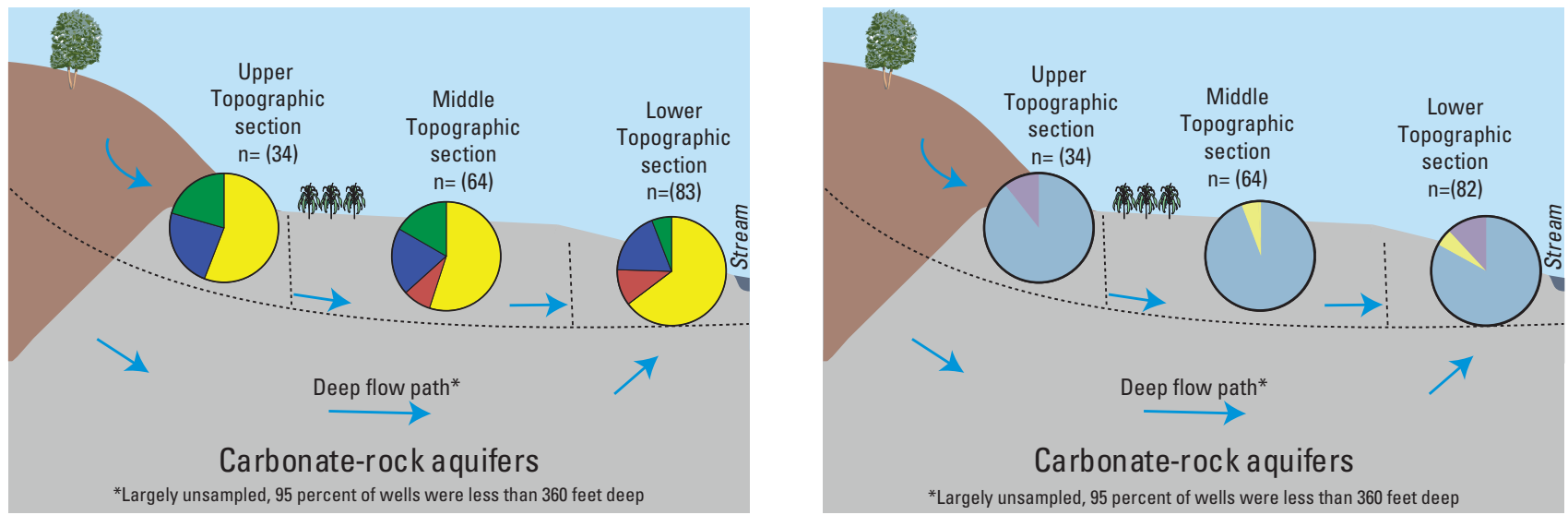

\section{EXPLANATION}

\begin{tabular}{|c|c|c|c|}
\hline $\begin{array}{l}\text { Land use overlying } \\
\text { aquifer }\end{array}$ & & Bedrock type & $\begin{array}{l}\text { Dominant redox } \\
\text { state by section }\end{array}$ \\
\hline$\square$ Agriculture & & - Siliciclastic & 0xic \\
\hline 口 Urban & & Carbonate & Mixed \\
\hline - Undeveloped & & & Anoxic \\
\hline & $\cdots$ & Section boundary & \\
\hline & $\mathrm{n}$ & $\begin{array}{l}\text { Number of wells } \\
\text { sampled in section }\end{array}$ & \\
\hline
\end{tabular}

Figure 14. Distribution of wells, land use surrounding wells, and dominant redox states by topographic sections within Valley and Ridge carbonate-rock aquifers, 1993-2002.
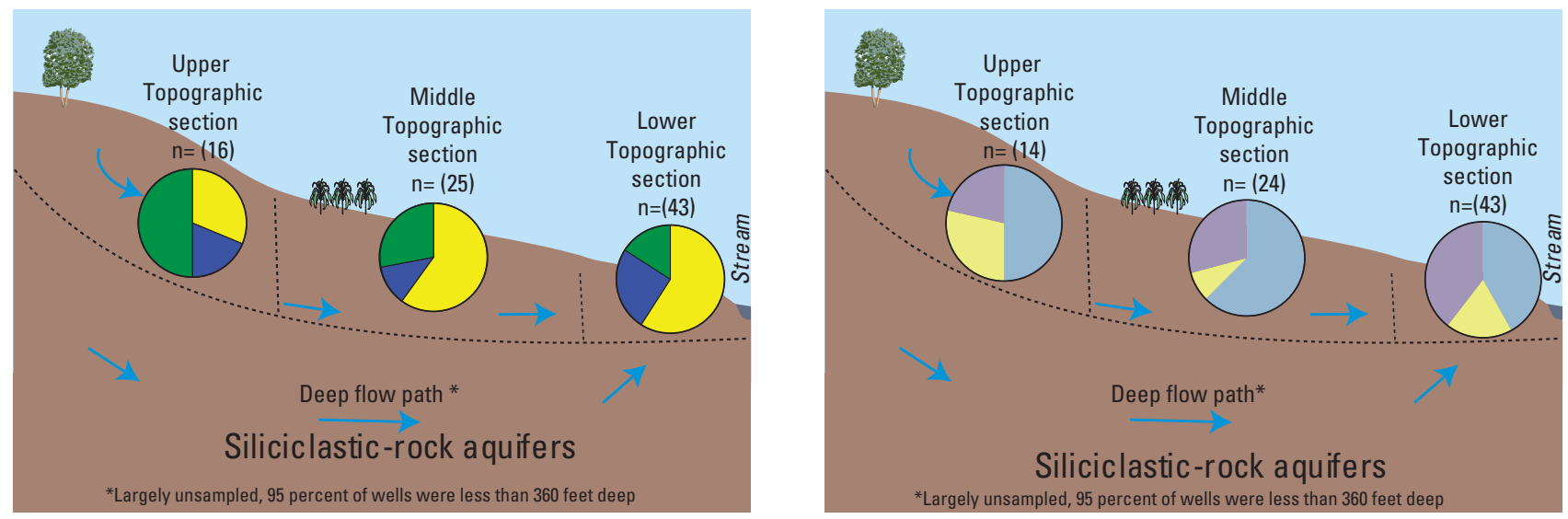

\section{EXPLANATION}
Land use overlying aquifer
$\square$ Agriculture
- Urban
- Undeveloped
- Mixed

\begin{tabular}{|c|c|c|}
\hline & Bedrock type & $\begin{array}{l}\text { Dominant redox } \\
\text { state by section }\end{array}$ \\
\hline & Siliciclastic & $\begin{array}{l}\text { Oxic } \\
\text { Mixed }\end{array}$ \\
\hline$\rightarrow$ & $\begin{array}{l}\text { Section boundary } \\
\text { Conceptual flow path }\end{array}$ & Anoxic \\
\hline $\mathrm{n}$ & $\begin{array}{l}\text { Number of wells } \\
\text { sampled in section }\end{array}$ & \\
\hline
\end{tabular}

Figure 15. Distribution of wells, land use surrounding wells, and dominant redox states by topographic sections within Valley and Ridge siliciclastic-rock aquifers, 1993-2002. 
Table 11. Spearman's rho correlations between normalized lateral position and water chemistry for Valley and Ridge carbonate-rock aquifers (without springs) and for selected topographic sections, 1993-2002.

[rho shown for variables statistically correlated at the 95-percent confidence level; NS, not statistically significant; n, number of observations; NLP, normalized lateral position].

\begin{tabular}{|c|c|c|c|c|}
\hline Variable & All & $\begin{array}{c}\text { Upper } \\
\text { topographic } \\
\text { section } \\
\text { NLP less than } 0.40\end{array}$ & $\begin{array}{c}\text { Middle } \\
\text { topographic } \\
\text { section } \\
\text { NLP } 0.40 \text { to } 0.70\end{array}$ & $\begin{array}{c}\text { Lower } \\
\text { topographic } \\
\text { section }\end{array}$ \\
\hline Dissolved oxygen concentration & NS & NS & $\begin{array}{c}-0.30 \\
(\mathrm{n}=50)\end{array}$ & $\begin{array}{c}-0.25 \\
(n=72)\end{array}$ \\
\hline Calcium concentration & NS & $\begin{array}{c}0.45 \\
(\mathrm{n}=23)\end{array}$ & NS & NS \\
\hline Strontium/ calcium ratio & NS & $\begin{array}{c}0.64 \\
(n=12)\end{array}$ & NS & NS \\
\hline Strontium concentration & NS & $\begin{array}{c}0.76 \\
(\mathrm{n}=12)\end{array}$ & NS & NS \\
\hline
\end{tabular}

Table 12. Spearman's rho correlations between normalized lateral position and water chemistry for Valley and Ridge siliciclastic-rock aquifers and for selected topographic sections, 1993-2002.

[SI, saturation index; n, number of observations; NLP, normalized lateral position; NS, not statistically significant]

\begin{tabular}{|c|c|c|c|c|}
\hline Variable & All & $\begin{array}{c}\text { Upper } \\
\text { topographic } \\
\text { section } \\
\text { NLP less than } 0.40\end{array}$ & $\begin{array}{c}\text { Middle } \\
\text { topographic } \\
\text { section } \\
\text { NLP } 0.40 \text { to } 0.70\end{array}$ & $\begin{array}{c}\text { Lower } \\
\text { topographic } \\
\text { section } \\
\text { NLP greater than } 0.70\end{array}$ \\
\hline Dissolved oxygen concentration & $\begin{array}{c}-0.32 \\
(n=82)\end{array}$ & NS & NS & $\begin{array}{c}-0.45 \\
(n=43)\end{array}$ \\
\hline Magnesium concentration & $\begin{array}{c}0.34 \\
(n=82)\end{array}$ & NS & NS & NS \\
\hline Specific conductance & $\begin{array}{c}0.32 \\
(n=82)\end{array}$ & NS & $\begin{array}{c}0.41 \\
(n=25)\end{array}$ & $\begin{array}{c}0.35 \\
(n=42)\end{array}$ \\
\hline Calcite SI & $\begin{array}{c}0.24 \\
(n=82)\end{array}$ & NS & NS & $\begin{array}{c}0.32 \\
(n=42)\end{array}$ \\
\hline Dolomite SI & $\begin{array}{c}0.27 \\
(n=82)\end{array}$ & NS & NS & $\begin{array}{c}0.32 \\
(n=42)\end{array}$ \\
\hline Sodium concentration & $\begin{array}{c}0.24 \\
(n=82)\end{array}$ & $\begin{array}{c}0.52 \\
(n=15)\end{array}$ & NS & NS \\
\hline
\end{tabular}

similarity between the aquifer types was a negative correlation between dissolved oxygen and NLP in samples in the lower topographic section. This pattern can be seen in increased anoxic conditions as water moves downgradient (fig. 15).

The results of the analysis of natural water chemistry and NLP are consistent with the concepts of groundwater aging along a flow path and the mixing of younger and older water near the end of a flow path. Samples with somewhat stronger correlations between natural water chemistry and NLP within siliciclastic-rock aquifers may reflect distinct topographic, lithologic, and land-use differences between siliciclastic- and carbonate-rock aquifers. The middle and lower topographic sections of siliciclastic landscapes are generally not as flat as those of carbonate-rock aquifers, and local groundwater recharge may be lower for siliciclastic-rock aquifers (Yager and others, 2009). Steeper gradients and limited local recharge in siliciclastic-rock aquifers would tend to preserve the effects of broader regional gradients and flow patterns. Also, the upper topographic section over siliciclastic-rock aquifers was substantially less developed than that overlying carbonate-rock aquifers, and the lower section overlying carbonate-rock aquifers was distinctly more urban than that overlying siliciclasticrock aquifers (figs. 14, 15). Few samples were collected from wells completed in areas along the forested ridges, and no samples were collected from wells in predominantly urban areas overlying siliciclastic-rock aquifers. 


\section{Selected Contaminants in Groundwater from the Valley and Ridge Aquifers and the Factors that Affect Their Occurrence}

The following sections discuss the occurrence and distribution of selected contaminants and analysis of the factors affecting contaminants in the Valley and Ridge aquifers. The analysis includes contaminants associated with human sources, such as nitrate, pesticides, VOCs, and fecal-indicator bacteria, as well as the naturally occurring contaminant, radon. Constituent concentrations were compared to explanatory variables, such as land use, source factors, geologic setting, and NLP. Comparisons also were made between networks because of different land-use practices and because of climatic differences for the TCM and TCS networks in the south and the other networks in the northern part of the Valley and Ridge, as well as other localized geological differences.

\section{Nitrate}

Nitrogen can take the form of organic nitrogen, ammonia $\left(\mathrm{NH}_{4}\right)$, nitrite $\left(\mathrm{NO}_{2}\right)$, or nitrate $\left(\mathrm{NO}_{3}\right)$. Of these, nitrate is of the greatest concern in groundwater. Nitrate is soluble in water, can easily leach through soil, and can persist in shallow groundwater for decades (Nolan, 1999). Human activities, including agricultural and urban uses of fertilizer, agricultural use of manure, and combustion of fossil fuel, have increased nitrate concentrations in shallow groundwater in many parts of the United States (U.S. Geological Survey, 1999). Elevated nitrate concentrations in drinking water can cause human health problems, notably methemoglobinemia, which is a potentially fatal condition in infants (Spalding and Exner, 1993). The USEPA established the MCL for nitrate at $10 \mathrm{mg} / \mathrm{L}$ as nitrogen (U.S. Environmental Protection Agency, 2006). Recent studies indicate possible adverse effects at nitrate concentrations below the MCL (Ward and others, 2005).

\section{Occurrence and Distribution of Nitrate}

Background concentrations of nitrate in shallow groundwater are typically about $2 \mathrm{mg} / \mathrm{L}$; concentrations exceeding this level probably reflect human activities (U.S. Geological Survey, 1999). Of 263 analyses for nitrate in groundwater from the Valley and Ridge aquifers, 16 percent had concentrations of nitrate below the detection limit of $0.05 \mathrm{mg} / \mathrm{L}$, 46 percent had concentrations above background levels of $2 \mathrm{mg} / \mathrm{L}$, and 12 percent (33 samples) had concentrations that exceeded the nitrate MCL of $10 \mathrm{mg} / \mathrm{L}$. All of the samples containing concentrations above the nitrate MCL were taken from domestic water-supply wells situated in agricultural areas in the northern part of the Valley and Ridge aquifers; all but three of these wells were completed in carbonate-rock aquifers. In general, median nitrate concentrations and the proportion of samples exceeding the MCL were greater for carbonate aquifers in the Valley and Ridge than for other carbonaterock aquifers studied by NAWQA, except for the Piedmont carbonate-rock aquifer where 63 percent of samples exceeded the nitrate MCL (Lindsey and others, 2009).

Nitrate concentrations in water from sites in the Valley and Ridge aquifers (fig. 16) may be influenced by a number of factors, including nitrogen inputs, land use, and well characteristics, such as rock type, NLP, and redox state. A categorical comparison of nitrate concentrations in samples from the 11 groundwater networks in the Valley and Ridge aquifers using Tukey's multiple-comparison test (MCT) showed lower median concentrations in samples from sites in siliciclastic-rock aquifers (median $=0.09 \mathrm{mg} / \mathrm{L}$ ) compared to carbonate-rock aquifers (median $=3.4 \mathrm{mg} / \mathrm{L}$ ) with the exception of the two southern networks (TCS and TCM) (fig. 17). Median nitrate concentrations exceeded $2 \mathrm{mg} / \mathrm{L}$ (background level) in water from wells in the four networks in northern carbonate-rock aquifers (excluding the reference network) but were below $2 \mathrm{mg} / \mathrm{L}$ for the Tennessee River basin carbonate-rock aquifer networks and for networks in siliciclastic-rock aquifers.

Land use can affect sources of nitrogen and interact with lithology to influence the distribution of nitrate on the landscape. Groundwater from sites in agricultural land-use areas and mixed land-use areas had higher median nitrate concentrations in carbonate-rock aquifers compared to samples from siliciclastic-rock aquifers (figure 18). Samples from the SCU network had a median nitrate concentration of $3.45 \mathrm{mg} / \mathrm{L}$ (fig. 17). Nearly all of the SCU wells were likely to have been influenced by agricultural activity upgradient as indicated by the coincident detection of low concentrations of agricultural pesticides. Concentrations of nitrate in water samples tended to decrease as the percentage of land use surrounding the site became less agricultural and more undeveloped, but differences were only statistically significant within the carbonaterock aquifer type (fig. 18).

The effects of topographic position are less clear and may be confounded by a relation to land use. Although not statistically significant, concentrations of nitrate appear to decrease in samples from sites in the upper to the lower topographic sections in the carbonate-rock aquifers (fig. 19). Although agricultural land use is high across all topographic sections over carbonate-rock aquifers, the decrease in nitrate concentrations observed may be explained by slight increases in anoxic conditions and mixing with older water near the end of the flow path (fig. 14). Similarly in the siliciclastic-rock aquifers, concentrations of nitrate are not significantly different among topographic sections, but tend to be highest in samples in the middle topographic section (fig. 19). Although the proportion of agricultural land is high in both the middle and lower topographic sections overlying siliciclastic-rock aquifers (fig. 15), the greater proportion of anoxic conditions in the lower topographic section may explain this pattern. 


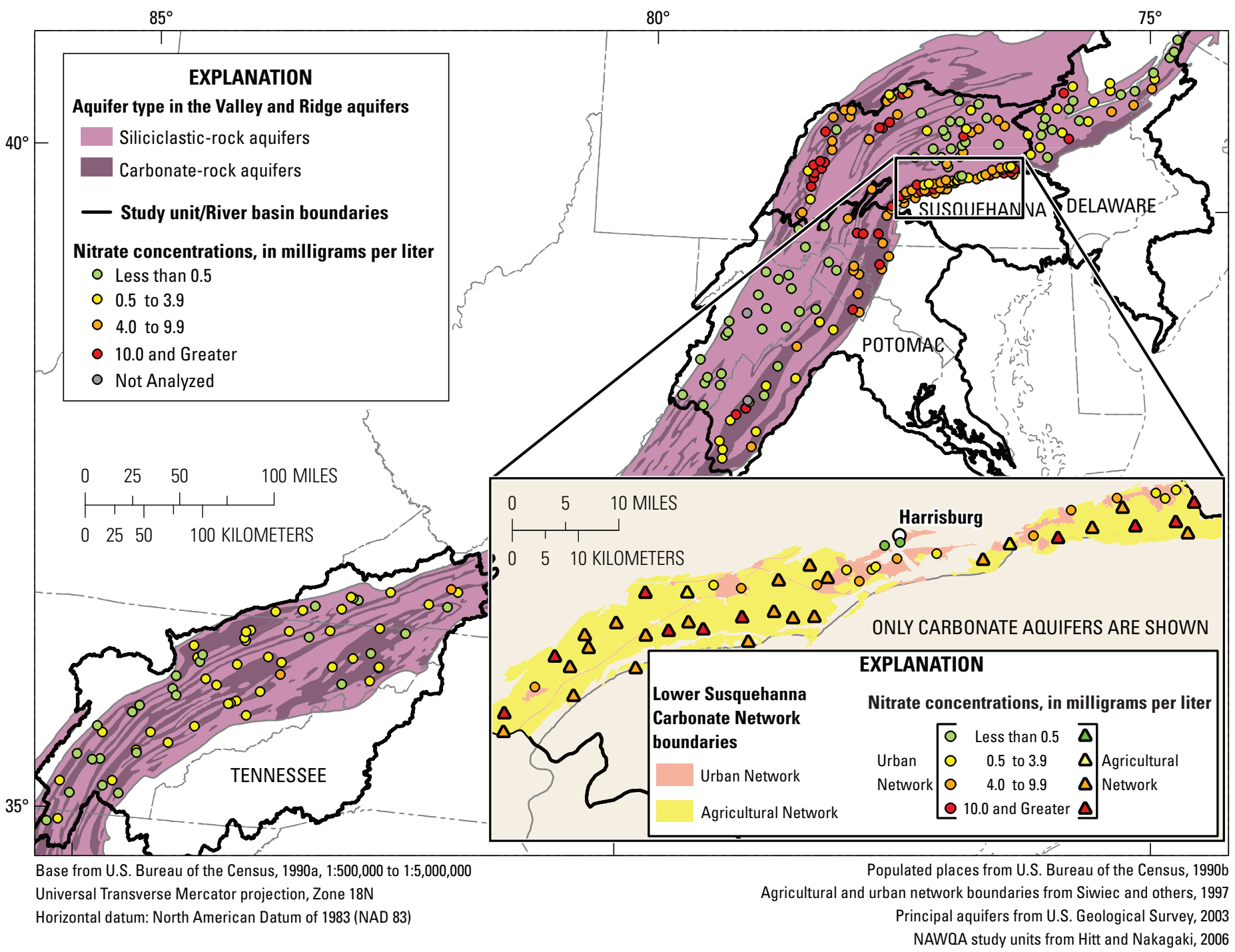

Figure 16. Nitrate distribution in the Valley and Ridge aquifers, 1993-2002. 


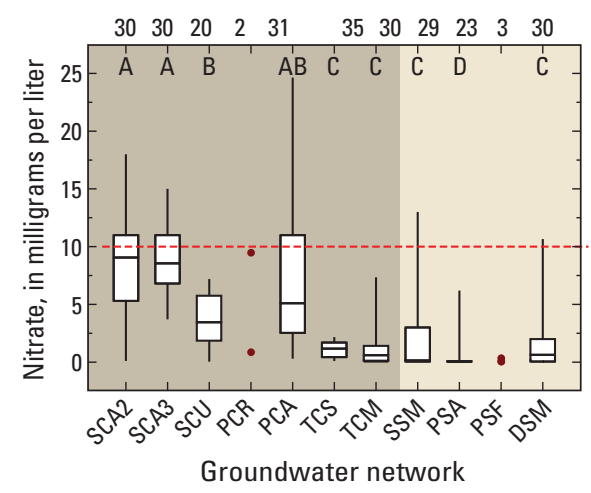

\section{EXPLANATION}

30 Number of samples

A Statistical group from nonparametric Tukey's test

Maximum value

75 th percentile

Median

25th percentile

Minimum value

- Individual data points

Siliciclastic-rock aquifers

Carbonate-rock aquifers

----- Maximum contaminant level for nitrate is

10 milligrams per liter

DSM Groundwater network code, see table 3 for network abbreviation codes

Figure 17. Nitrate concentrations by network for samples from the Valley and Ridge aquifers, 1993-2002.

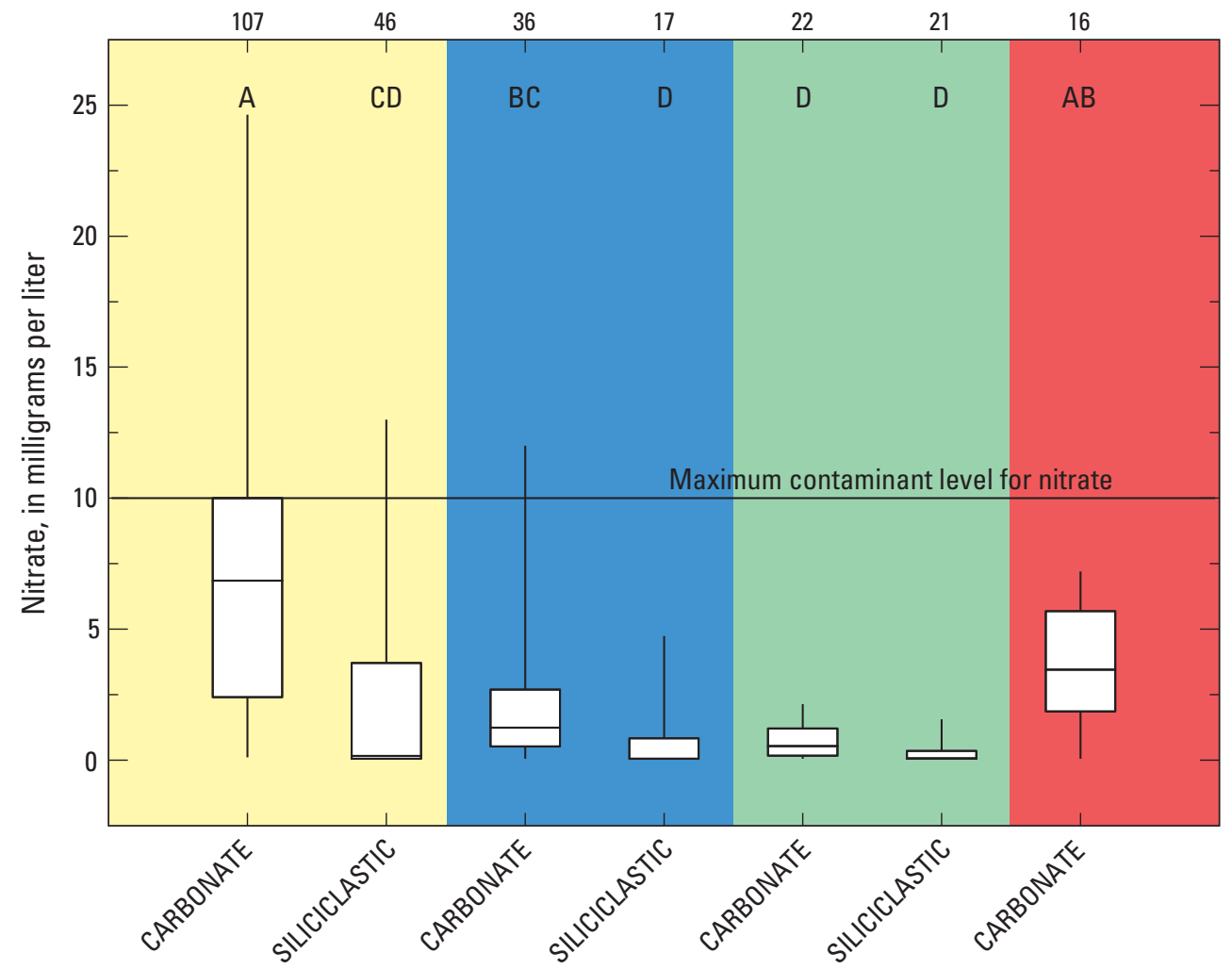

\section{EXPLANATION}

46 Number of samples

A Statistical group from nonparametric Tukey's test

Maximum value

75th percentile Median

25th percentile

Minimum value

Land-use categories

Mixed

Undeveloped

Urban

Agricultural

Figure 18. Nitrate concentrations in groundwater samples from the Valley and Ridge aquifers grouped by land use and aquifer type, 1993-2002. 


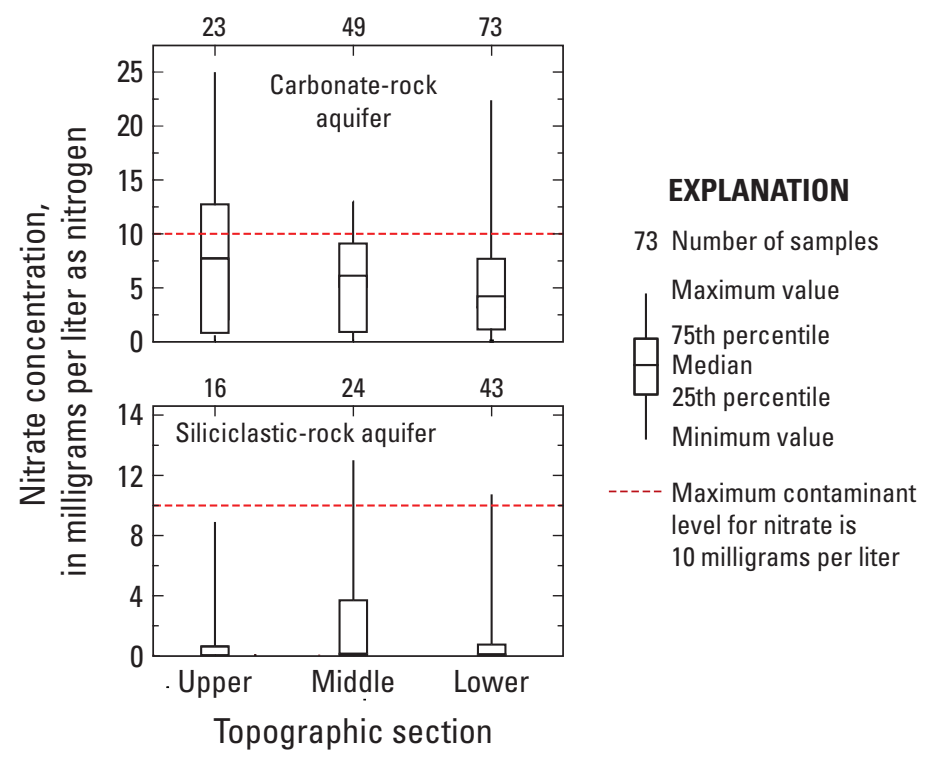

Figure 19. Distribution of nitrate concentrations by topographic section and aquifer type in the Valley and Ridge aquifers, 1993-2002.

\section{Factors Affecting Nitrate Concentrations}

Nitrate concentrations were positively correlated to dissolved oxygen for all samples and for both aquifer types (table 13). The NLP was not correlated with nitrate concentrations for all topographic sections combined, except within carbonate-rock aquifers when the springs were removed from the dataset (table 13). When NLP is grouped by topographic sections (upper, middle, and lower topographic sections) a number of correlations become apparent. The combined carbonate- and siliciclastic-rock aquifers dataset may be a good representation of actual field conditions, with siliciclastic bedrock units forming ridges and carbonate bedrock units typically in the valleys. For the combined dataset, the upper topographic section had increasing nitrate concentrations as the NLP increased $(r h o=0.37)$. In the lower topographic section, the nitrate and dissolved oxygen concentrations decreased with increasing NLP, indicating anoxic conditions and the possibility of denitrification. When the carbonaterock aquifer networks were evaluated separately, the nitrate concentrations in samples in the upper topographic section were positively correlated with the NLP $(r h o=0.41)$ and were negatively correlated with the NLP in the lower topographic section (table 13). In the lower topographic section, dissolved oxygen concentrations were negatively correlated with NLP for the carbonate-rock aquifers (excluding springs) (table 11) and the siliciclastic-rock aquifers (table 12). The distance to the nearest stream was positively correlated with nitrate concentrations for both aquifer types and for carbonate-rock aquifers without springs. Specific conductance concentrations were positively correlated to nitrate concentrations for samples from carbonate-rock aquifers (table 13).

The results of correlation analyses comparing nitrate concentrations to land-use characteristics and nitrogen sources are shown in table 14 and figure 18 . World-wide, fertilizer is the largest anthropogenic source of nitrogen to watersheds, but other sources include animal and human waste and exhaust from automobiles and utilities (Fields, 2004). Agricultural fertilizer and manure from confined animal operations each contributed about 30 percent of total inputs of nitrogen to the lands immediately surrounding network wells in the Valley and Ridge. Manure from unconfined animals contributed 19 percent of the total, atmospheric deposition contributed 12 percent, non-agricultural fertilizer contributed 0 percent, and septic systems contributed about 1.3 percent (table 15). Atmospheric deposition was the predominant source of nitrogen in undeveloped areas (PSF and PCR networks). In areas of low-intensity agriculture (parts of TCM and TCS) unconfined animal manure contributed the most nitrogen, and in urban areas (SCU), non-agricultural fertilizer for lawn care was a dominant source of nitrogen (table 15).

Nitrate concentrations were most strongly correlated to land use ( $r h o=0.67$ for agricultural land use) and nitrogen inputs ( $r h o=0.54$ for total nitrogen inputs) for samples from the relatively oxic carbonate-rock aquifers (table 14). Samples from siliciclastic-rock aquifers, where conditions are more likely to be anoxic, tend to show weaker correlations. Combining carbonate- and siliciclastic-rock aquifer data into a single analysis (all data) shows some residual correlation but less than for carbonate-rock aquifers alone. Urban land use was 
Table 13. Summary of Spearman's rho correlations between nitrate concentrations and explanatory variables for normalized lateral position and general water-quality values in groundwater in the Valley and Ridge aquifers, 1993-2002.

[rho shown for variables statistically correlated at the 95-percent confidence level; n, number of samples; NS, not statistically significant]

\begin{tabular}{|c|c|c|c|c|}
\hline Explanatory variable & $\begin{array}{c}\text { All data } \\
\text { (n=263, except } \\
\text { where noted) }\end{array}$ & $\begin{array}{l}\text { Carbonate aquifers } \\
\text { (n=180, except } \\
\text { where noted) }\end{array}$ & $\begin{array}{c}\text { Carbonate aquifers } \\
\text { without springs } \\
\text { ( } \mathrm{n}=145, \text { except } \\
\text { where noted) }\end{array}$ & $\begin{array}{c}\text { Siliciclastic aquifers } \\
\text { (n=83, except } \\
\text { where noted) }\end{array}$ \\
\hline \multicolumn{5}{|c|}{ Normalized lateral position } \\
\hline Distance to nearest stream & 0.34 & 0.43 & 0.23 & 0.32 \\
\hline Distance to major stream & 0.36 & 0.23 & 0.27 & 0.22 \\
\hline Distance to nearest ridge & 0.30 & NS & NS & NS \\
\hline Normalized lateral position (all) & NS & NS & -0.20 & NS \\
\hline Upper & 0.37 & 0.41 & 0.50 & NS \\
\hline Middle & NS & NS & NS & NS \\
\hline Lower & -0.31 & -0.30 & -0.28 & -0.42 \\
\hline \multicolumn{5}{|c|}{ General water quality } \\
\hline Alkalinity & $\begin{array}{c}0.44 \\
(\mathrm{n}=261)\end{array}$ & 0.32 & NS & $\begin{array}{c}-0.28 \\
(\mathrm{n}=81)\end{array}$ \\
\hline Dissolved Oxygen & $\begin{array}{c}0.59 \\
(\mathrm{n}=260)\end{array}$ & $\begin{array}{c}0.40 \\
(\mathrm{n}=179)\end{array}$ & $\begin{array}{c}0.50 \\
(\mathrm{n}=144)\end{array}$ & $\begin{array}{c}0.60 \\
(\mathrm{n}=81)\end{array}$ \\
\hline Specific Conductance & $\begin{array}{c}0.55 \\
(\mathrm{n}=261)\end{array}$ & 0.56 & 0.44 & NS \\
\hline
\end{tabular}

Table 14. Summary of Spearman's rho correlations between nitrate concentrations and explanatory variables for land use and nitrogen sources in groundwater in the Valley and Ridge aquifers, 1993-2002.

[rho shown for variables statistically correlated at the 95-percent confidence level; n, number of samples; NS, not statistically significant]

\begin{tabular}{|c|c|c|c|c|}
\hline Explanatory variable & $\begin{array}{c}\text { All data } \\
\text { ( } n=263 \text {, except } \\
\text { where noted) }\end{array}$ & $\begin{array}{c}\text { Carbonate aquifers } \\
\text { (n=180, except } \\
\text { where noted) }\end{array}$ & $\begin{array}{l}\text { Carbonate aquifers } \\
\text { without springs } \\
\text { (n=145, except } \\
\text { where noted) }\end{array}$ & $\begin{array}{l}\text { Siliciclastic aquifers } \\
\qquad(\mathrm{n}=\mathbf{8 3})\end{array}$ \\
\hline \multicolumn{5}{|c|}{ 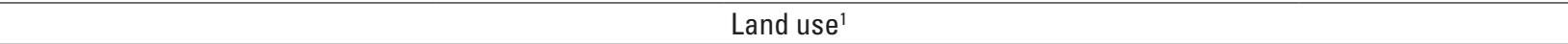 } \\
\hline Agricultural & 0.59 & 0.67 & 0.67 & 0.34 \\
\hline Pasture & 0.39 & 0.46 & 0.41 & NS \\
\hline Row crop & 0.56 & 0.62 & 0.62 & 0.37 \\
\hline Urban & NS & -0.25 & -0.28 & NS \\
\hline Forested & -0.66 & -0.65 & -0.56 & -0.35 \\
\hline Population density 2000 & 0.25 & NS & NS & 0.32 \\
\hline \multicolumn{5}{|c|}{ Nitrogen sources } \\
\hline Nitrogen from septic systems ${ }^{2}$ & 0.19 & NS & NS & 0.36 \\
\hline Agricultural fertilizer ${ }^{3}$ & $\begin{array}{c}0.55 \\
(n=260)\end{array}$ & $\begin{array}{c}0.53 \\
(n=177)\end{array}$ & $\begin{array}{c}0.58 \\
(n=142)\end{array}$ & 0.47 \\
\hline Confined-agricultural manure ${ }^{3}$ & $\begin{array}{c}0.42 \\
(n=260)\end{array}$ & $\begin{array}{c}0.64 \\
(n=177)\end{array}$ & $\begin{array}{c}0.60 \\
(n=142)\end{array}$ & NS \\
\hline Unconfined-agricultural manure ${ }^{3}$ & $\begin{array}{c}0.21 \\
(n=260)\end{array}$ & NS & NS & NS \\
\hline Atmospheric deposition $^{3}$ & $\begin{array}{c}-0.19 \\
(n=260)\end{array}$ & $\begin{array}{c}-0.30 \\
(n=177)\end{array}$ & $\begin{array}{c}-0.19 \\
(n=142)\end{array}$ & -0.33 \\
\hline Total nitrogen input & $\begin{array}{c}0.49 \\
(\mathrm{n}=260)\end{array}$ & $\begin{array}{c}0.54 \\
(n=177)\end{array}$ & $\begin{array}{c}0.55 \\
(\mathrm{n}=144)\end{array}$ & NS \\
\hline
\end{tabular}

${ }^{1}$ Vogelmann and others, 2001; Price and others, 2007.

${ }^{2}$ U.S. Bureau of the Census, 1990a, 1992a, 1992b.

${ }^{3}$ Ruddy and others, 2006. 


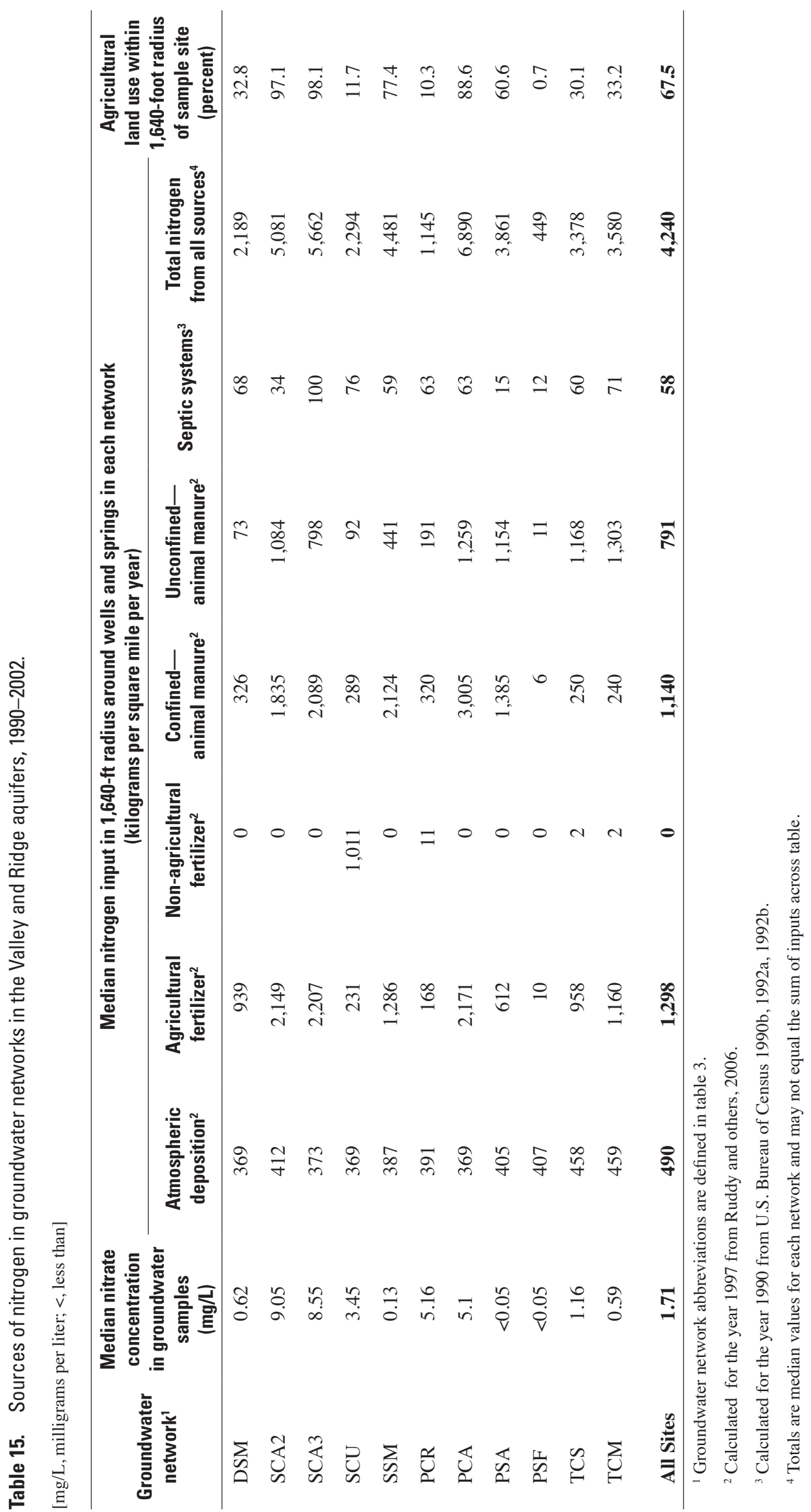


negatively correlated to nitrate concentrations (table 14), and row crops were more strongly and positively correlated to nitrate concentrations than pasture, reflecting higher fertilizer application for row crops. Forested area was negatively correlated to nitrate concentration. The inclusion of springs in this analysis had little to no effect on correlations between nitrate concentrations and environmental factors in carbonate-rock aquifers (table 14).

Nitrate was variably correlated to several input sources of nitrogen. Agricultural fertilizer as a source of nitrogen was correlated to nitrate concentration in samples from both carbonate- and siliciclastic-rock aquifer types ( $r h o=0.53$ and 0.47 , respectively); however, nitrogen inputs from unconfined agricultural manure were not well correlated with nitrate concentrations in samples from either aquifer type. Nitrogen from septic systems was significantly correlated with nitrate concentration only in the siliciclastic-rock aquifers $(r h o=0.36$ ), and nitrogen from confined-animal manure showed reasonably strong correlation to nitrate only in carbonate-rock aquifers $($ rho $=0.64)$. Atmospheric deposition from 1997 was negatively correlated to nitrate in carbonate-rock aquifers ( $r h o=$ $-0.30)$ and in siliciclastic-rock aquifers $(r h o=-0.33)$. The reason for this is not entirely clear. To the extent that atmospheric (wet) deposition rates vary across the Valley and Ridge, they may reflect annual rainfall and orographic patterns that favor greater inputs on higher and undeveloped slopes where other inputs are less.

Nitrate concentrations can be correlated to a number of soil characteristics and soil groups (table 16). The correlation between nitrate concentration and percentage of clay was negative for carbonate-rock aquifers and positive for siliciclastic-rock aquifers. Silt was positively correlated and sand negatively correlated to the nitrate concentrations for carbonate- and siliciclastic-rock aquifers. Correlations of nitrate to hydrologic soils groups tended to be stronger when aquifer types were combined. The strongest positive correlation was with the presence of group B (medium-low runoff potential); the strongest negative correlation was with the presence of group C (slow infiltration rates) and D (high runoff potential). Generally, the lower the runoff potential, the more infiltration and the greater potential for transport into aquifers.

\section{Pesticides}

Groundwater samples from the Valley and Ridge aquifers were analyzed for 47 common pesticides and degradation products; more than half of the samples contained no pesticides or degradation products above detection levels (table 17). During the periods of these analyses, reporting levels varied for many of the 47 compounds; therefore, some constituent data are censored at multiple detection levels. Some values were qualified as "estimated" when uncertainties in analytical methods were large. Three evaluation criteria (laboratory reporting level, any concentration, and common assessment level) were applied to detection frequency data. A laboratory reporting level is the concentration below which a compound cannot be identified with certainty. Because a given

Table 16. Summary of Spearman's rho correlations between nitrate concentrations in groundwater and explanatory variables for hydrogeology and soils for the Valley and Ridge aquifers, 1993-2002.

[rho shown for variables statistically correlated at the 95-percent confidence level; n, number of samples; NS, not statistically significant]

\begin{tabular}{|c|c|c|c|c|}
\hline Hydrogeology and soils ${ }^{1}$ & $\begin{array}{c}\text { All data } \\
\text { ( } \mathrm{n}=263, \text { except } \\
\text { where noted) }\end{array}$ & $\begin{array}{c}\text { Carbonate } \\
\text { aquifers } \\
(n=180)\end{array}$ & $\begin{array}{c}\text { Carbonate } \\
\text { aquifers without } \\
\text { springs } \\
(\mathrm{n}=145)\end{array}$ & $\begin{array}{c}\text { Siliciclastic } \\
\text { aquifers } \\
\text { (n=83, except } \\
\text { where noted) }\end{array}$ \\
\hline Water level & $\begin{array}{c}0.24 \\
\mathrm{n}=214\end{array}$ & NS & NS & $\begin{array}{c}0.30 \\
\mathrm{n}=73\end{array}$ \\
\hline Percent organic matter & -0.12 & 0.39 & 0.32 & -0.22 \\
\hline Percent clay & 0.34 & -0.25 & NS & 0.29 \\
\hline Percent silt & 0.49 & 0.56 & 0.48 & 0.45 \\
\hline Percent sand & -0.66 & -0.59 & -0.52 & -0.37 \\
\hline Percentage soil in hydrologic group A & -0.34 & NS & NS & -0.36 \\
\hline Percentage soil in hydrologic group B & 0.45 & NS & 0.19 & 0.24 \\
\hline Percentage soil in hydrologic group C & -0.38 & NS & -0.20 & NS \\
\hline Percentage soil in hydrologic group D & -0.37 & -0.30 & -0.26 & NS \\
\hline
\end{tabular}

${ }^{1}$ Foth and Schafer, 1980; U.S. Department of Agriculture, Natural Resources Conservation Service, 1994; Wolock, 1997; Barbara C. Ruddy and William A. Battaglin, U.S. Geological Survey, written commun., 1998; U.S. Department of Agriculture, 2003. 


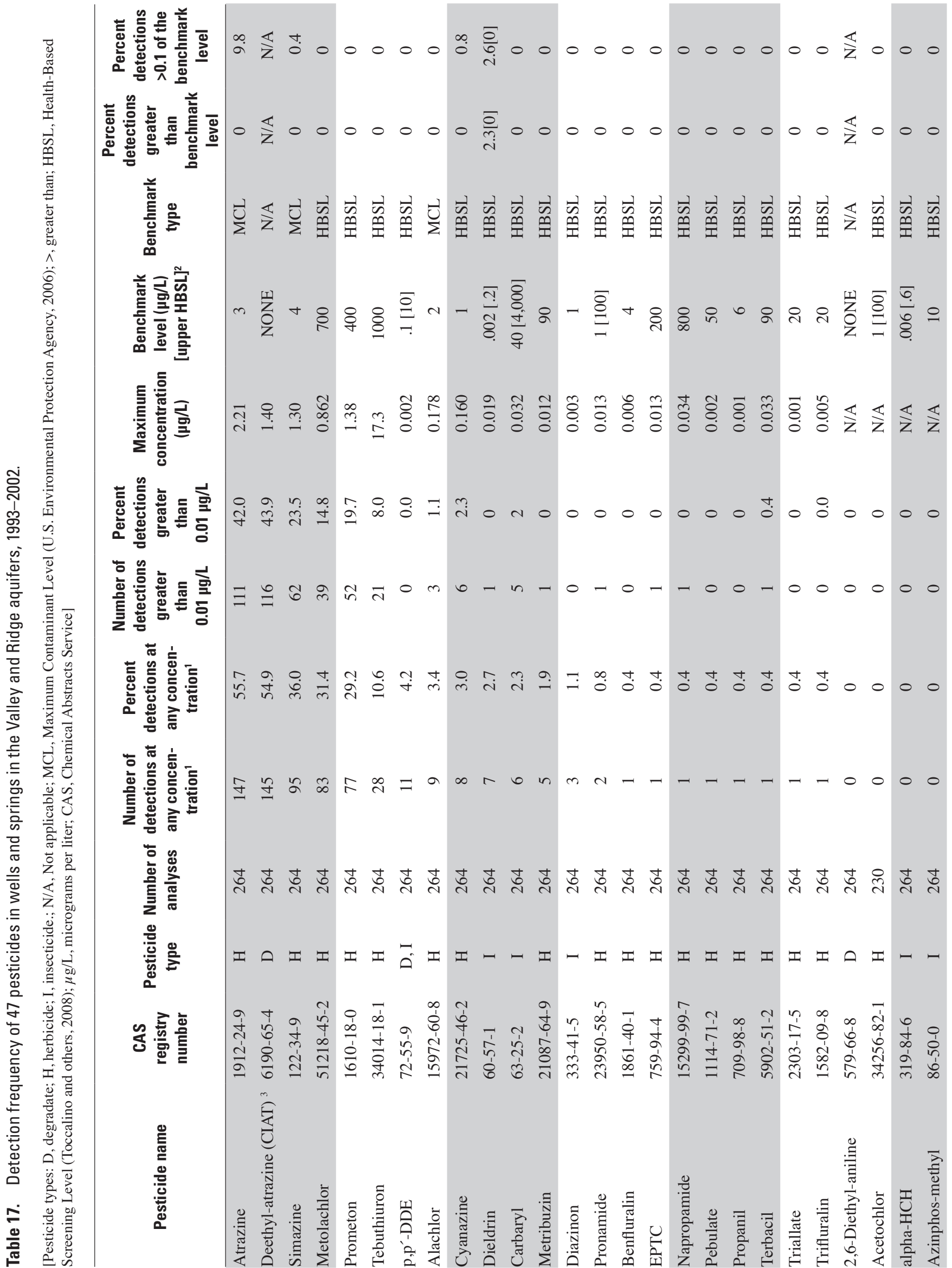




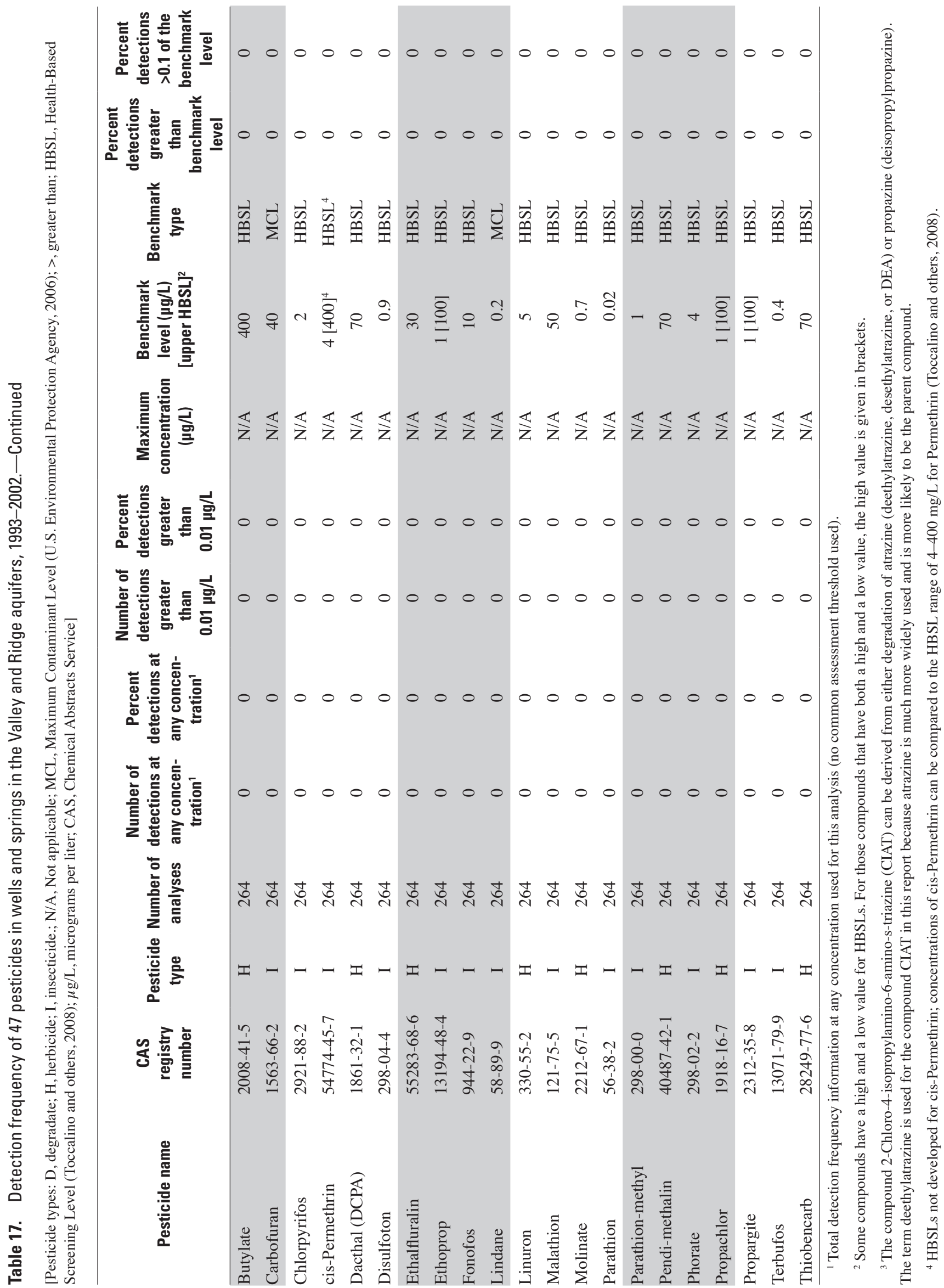


compound may be present in a sample at very low concentrations, non-detects are reported as "less than" the minimum reporting levels for the analytical method. The qualifier "at any concentration" in table 17 refers to the number of estimated values and quantified detections (above any of the multiple reporting levels). This approach was used to calculate overall detection frequency for each pesticide as described by Gilliom and others (2006). Additional censoring of results to a common assessment level facilitates a comparison of detection frequencies and median concentrations among compounds with different reporting levels. A common assessment level of $0.01 \mu \mathrm{g} / \mathrm{L}$ was useful for this purpose. As such, any values (reported or estimated) below $0.01 \mu \mathrm{g} / \mathrm{L}$ were classified as non-detects.

\section{Occurrence and Distribution of Pesticides}

In general, pesticides and their degradation products were fairly common in groundwater samples from the Valley and Ridge aquifers. Almost half of the pesticide compounds analyzed (22 of 47) were detected in at least one sample (table 17), and detections of more than one pesticide compound in the same sample were common (fig. 20). At least one pesticide or degradate was detected in about 65 percent of the samples from wells and springs in the aquifers. Overall, detection frequency was greatest in samples from the Susquehanna carbonate-rock aquifers in agricultural and urban networks (SCA2, SCA3, and SCU) where 3 or more pesticides were detected in 88 percent of the samples ( 70 of 80 ) and 5 or more pesticides were detected in 56 percent of the samples (45 of 80) (fig. 21A). Multiple pesticide compounds were more frequently detected in samples with an oxic redox state (fig. 21B). Multiple pesticide compounds were more frequently detected in samples from wells completed in agricultural, urban, or mixed land-use settings (fig. 21C) and in samples from carbonate-rock aquifers (fig. 21D).

The pesticides most frequently detected in samples of groundwater from the Valley and Ridge aquifers were herbicides, an herbicide degradation product, and an insecticide degradation product. The herbicide atrazine and its degradation product, deethylatrazine (also known as CIAT), were the pesticides most frequently detected. Atrazine and deethylatrazine were detected in 56 percent and 55 percent of samples, respectively (table 17). Four other herbicides - simazine, metolachlor, prometon, and tebuthiuron - and $p, p$ '-DDE, a degradation product of the insecticide DDT, were detected in at least 10 samples (table 18). Not surprisingly, samples from wells in agricultural land-use networks (SCA2, SCA3, and PCA) had frequent detections of the agricultural herbicides atrazine and metolachlor (fig. 22) and the general-use herbicides simazine, prometon, and tebuthiuron (table 18). Less expected was the frequent presence of all of these pesticides in samples from the urban land-use network (SCU).

Generally, samples from the major aquifer networks had the fewest detections of herbicides, reflecting the various land uses in these networks. Although, the highest concentration of any single pesticide in any network (tebuthiuron at $17.3 \mu \mathrm{g} / \mathrm{L}$; table 17) was in a sample from a well in the TCM network, the frequency of pesticide detections in the TCM network otherwise was quite low (table 18). The number of detections of herbicides was somewhat higher in the TCS network compared to the other major aquifer networks and the PSA network but was lower than in samples from sites in agricultural and urban networks in carbonate-rock aquifers (table 18).

Samples from networks in siliciclastic-rock aquifers had fewer detections of herbicides than samples from networks in carbonate-rock aquifers, without respect to land use. Median agricultural land use for wells in the Potomac carbonate- and siliciclastic-rock aquifer agricultural networks (PCA and PSA) were 89 and 61 percent, respectively (table 6). Although agricultural land use is somewhat less in the PSA network compared to the PCA network, the difference in the number of pesticide detections was appreciable (5 for the PSA compared to 111 for the PCA).

\section{Assessment of Potential Effects of Pesticides on Human Health}

No samples of water from the Valley and Ridge aquifers had pesticide concentrations that exceeded any USEPA MCLs. The only pesticide analyzed in the Valley and Ridge aquifers to exceed an HBSL (non-enforceable) was the insecticide dieldrin. Six groundwater samples had dieldrin concentrations greater than the HBSL of $0.002 \mu \mathrm{g} / \mathrm{L}$; the highest concentration measured was $0.019 \mu \mathrm{g} / \mathrm{L}$. Three of these six samples were from wells used as sources of drinking water, two were used for private domestic supplies, and one was used for public supply. All three of these wells were in the SCU network (fig. 23). Dieldrin was discontinued for most agricultural uses in 1974 and for all uses in 1987 (U.S. Environmental Protection Agency, 2003), but remains in the environment as a persistent, bioaccumulative, and toxic pollutant.

Because most of the wells and springs sampled in the Valley and Ridge aquifers were used as sources of drinking water, a concentration greater than one-tenth of a humanhealth benchmark (either enforceable MCLs or non-enforceable HBSLs) was used in this study to provide an indication of contaminants that may approach concentrations of potential human-health concern and to identify those that may warrant additional monitoring and study (Toccalino and others, 2008; DeSimone and others, 2009). The ratio of a pesticide concentration to its human-health benchmark is referred to as a benchmark quotient. Benchmark quotients greater than 0.1 but less than or equal to 1.0 indicate concentrations approaching levels of a potential human-health concern; benchmark quotients greater than 1.0 indicate levels above the threshold of a potential human-health concern (Toccalino and others, 2008). Benchmark quotients were calculated for unregulated carcinogenic compounds using the lower of two HBSL exposure thresholds.

Within the Valley and Ridge aquifers, four pesticides were at or were approaching levels of potential human-health 


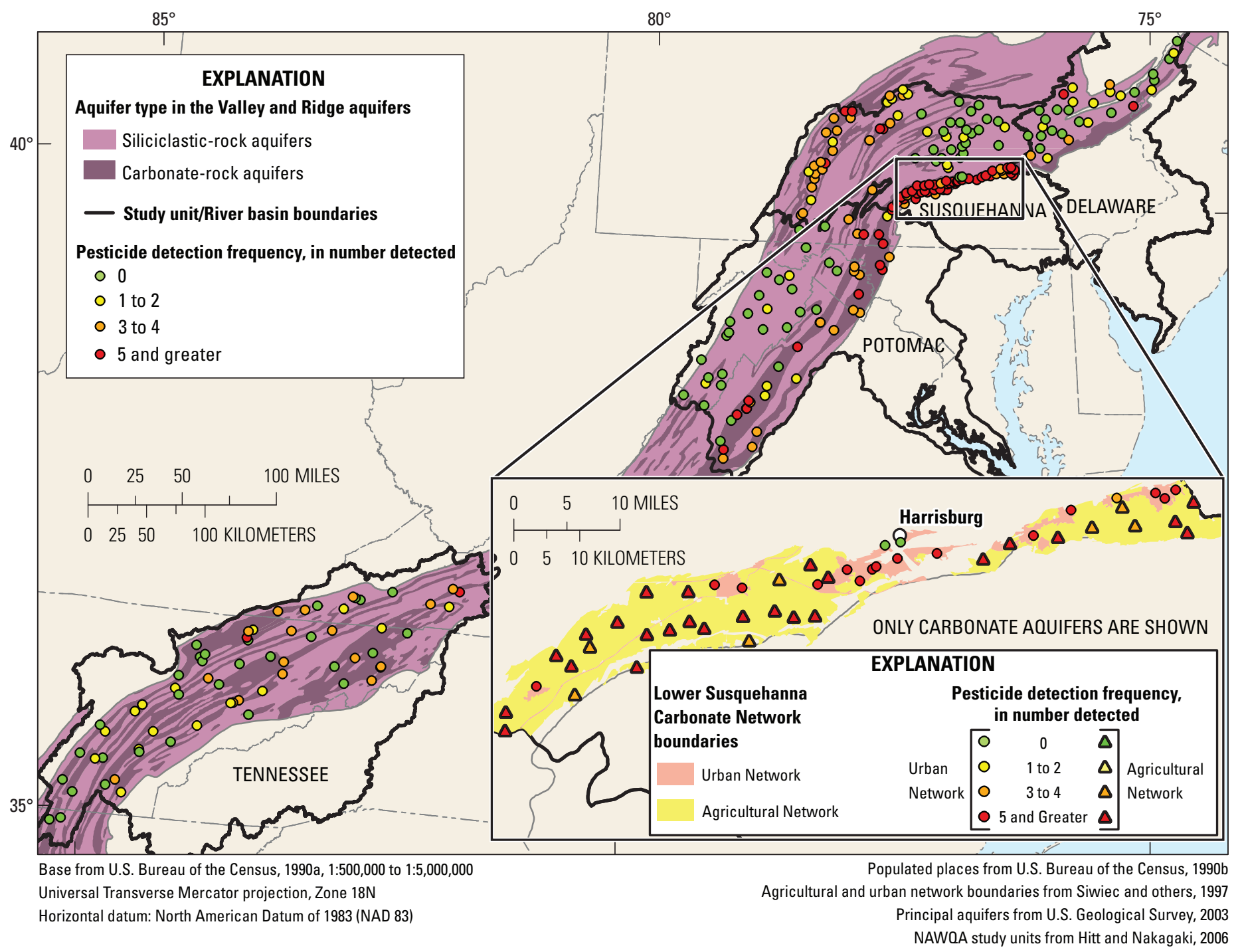

Figure 20. Sample locations and pesticide detection frequency at any concentration in groundwater samples from wells and springs in the Valley and Ridge aquifers, 1993-2002. 

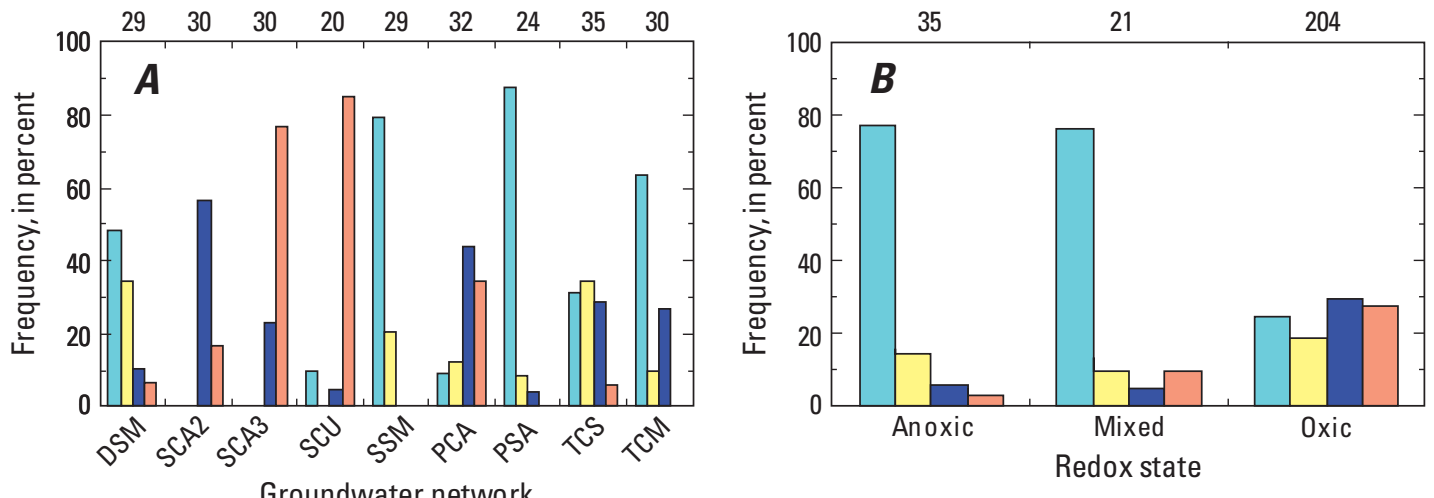

\section{EXPLANATION}

30 Number of samples

Number of pesticides detected per sample $\square$ None

1 to 2 detected 3 to 4 detected
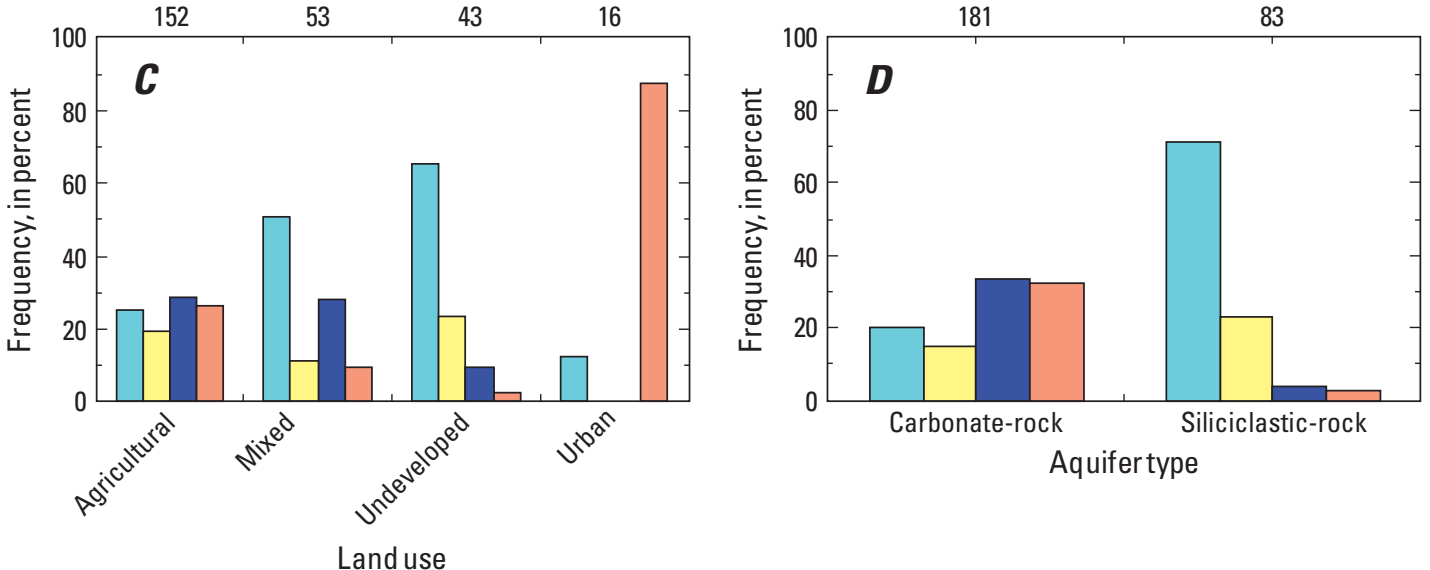

DSM Groundwater network code, see table 3 for network abbreviation codes

Figure 21. Groundwater samples with zero, one to two, three to four, and five or more pesticide compounds at any concentration in relation to, $A$, groundwater network, $B$, redox state, $C$, land-use classification, and, $D$, aquifer type. Results are based on analysis of 47 pesticide compounds in groundwater samples from the Valley and Ridge aquifers, 1993-2002.

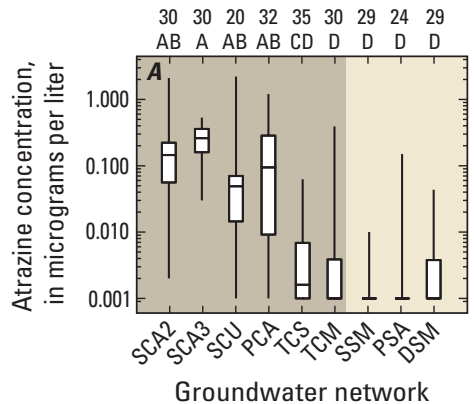

\section{EXPLANATION}

30 Number of samples

A Statistical group from nonparametric Tukey's

test

Maximum value

75th percentile

- Median

25th percentile

Minimum value

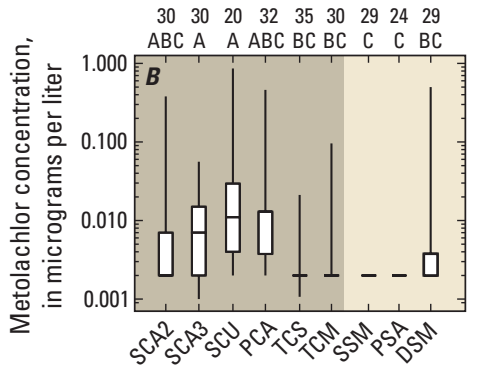

Siliciclastic-rock aquifers

Carbonate-rock aquifers

DSM Groundwater network code, see table 3 for network abbreviation codes

Figure 22. Distribution of, $A$, atrazine and, $B$, metolachlor concentrations in groundwater samples from well and spring networks in the Valley and Ridge aquifers, 1993-2002. 


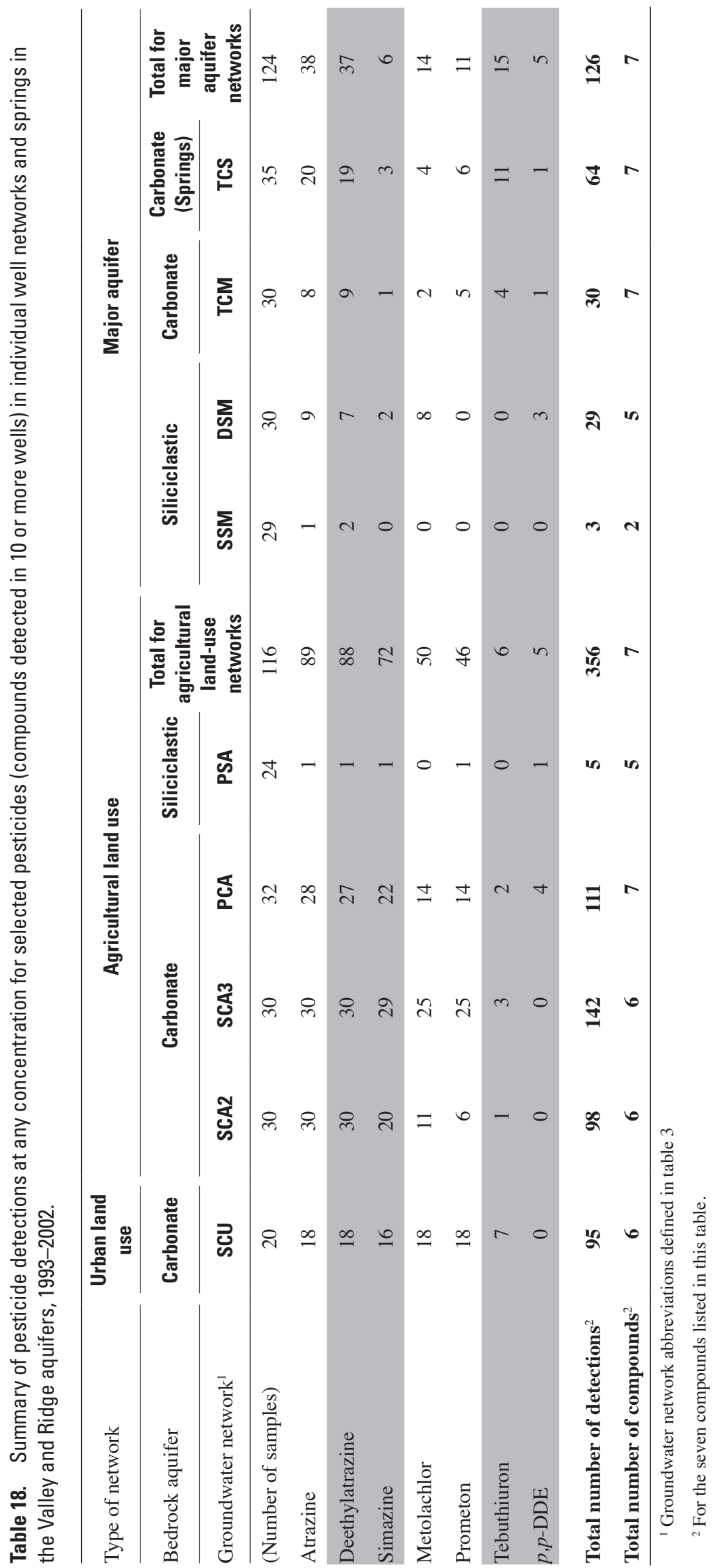



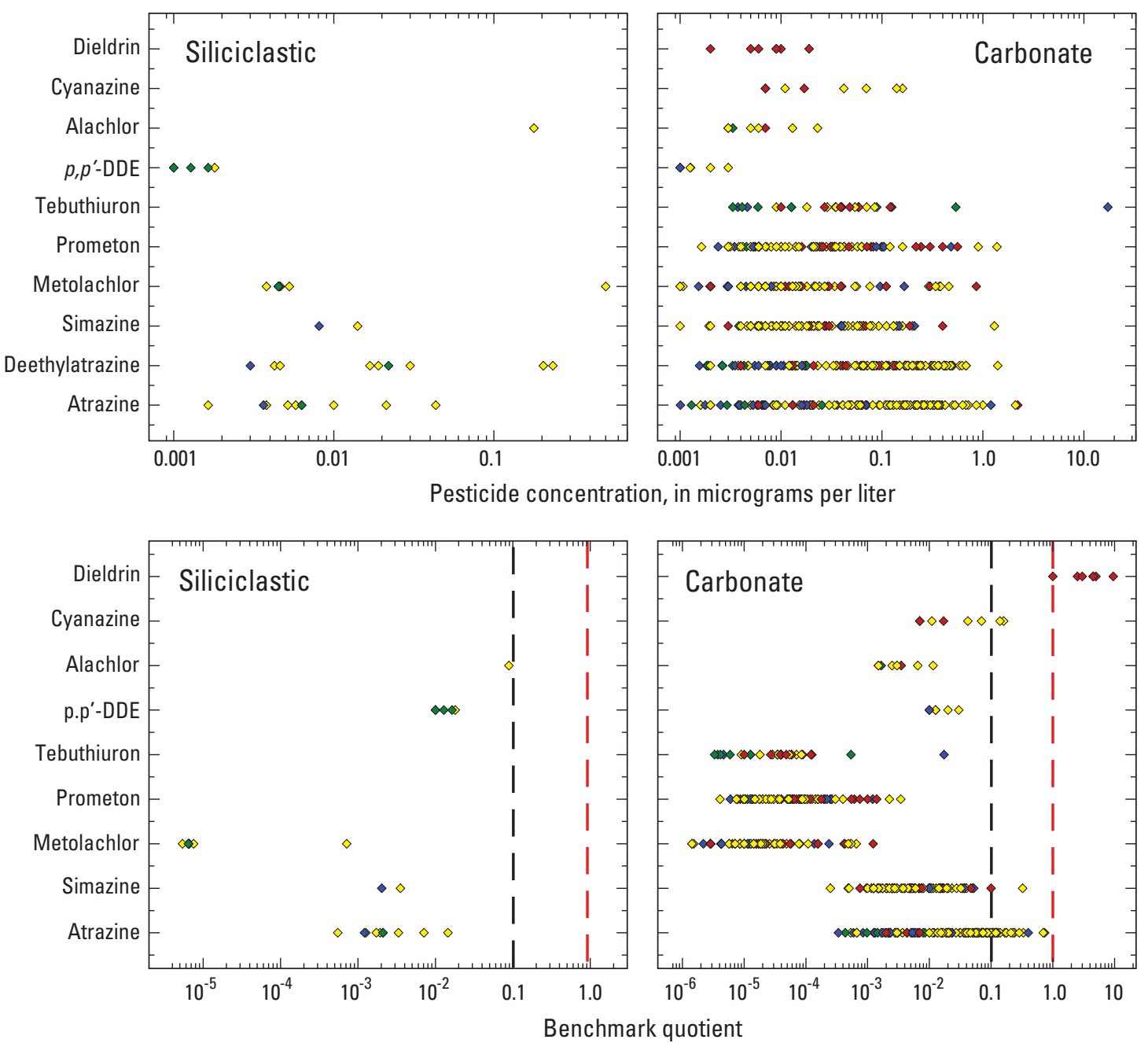

EXPLANATION

Land Use

$\diamond$ Agricultural

- Mixed

- Undeveloped

- Urban

Benchmark quotient value $(\mathrm{BO})=\frac{\text { Atrazine concentration }}{\text { Atrazine } \mathrm{MCL}=3 \mu \mathrm{g} / \mathrm{L}}$

Benchmark Quotient value of 0.1 -- Values

greater than this line are within one order

of magnitude of an MCL or HBSL

MCL is Maximum Contaminant Level for regulated compounds

(U.S. Environmental Protection Agency, 2006).

HBSL is Health-Based Screening Level concentrations for

unregulated compounds (Toccalino and others, 2008).

Benchmark quotient value of 1.0 -- Values

greater than this line would indicate concentrations

of potential health concerns

Figure 23. Concentrations and benchmark quotient values of the most common pesticides in areas underlain by carbonate- and siliciclastic-rock aquifers stratified by various land-use categories in the Valley and Ridge aquifers, 1993-2002. 
concerns - atrazine, simazine, cyanazine, and dieldrin (table 17 and fig. 23). Although deethylatrazine is frequently detected in network samples, human-health benchmarks for this constituent have not been established; therefore, no benchmark quotient could be computed. Detections of atrazine and simazine in samples from sites in carbonate-rock aquifers had benchmark quotients between 0.1 and 1.0 , and the samples were primarily from agricultural settings. Of the 27 benchmark quotients above 0.1 for atrazine, 18 were for samples from well networks SCA2, SCA3, and SCU (16 of the 18 samples were from domestic supply wells); 8 were for samples from PCA wells, all of which were used for domestic supply; and 1 was for a sample from the TCS spring network, which was not used for drinking-water supply. Cyanazine was detected in water samples from two domestic supply wells in agricultural areas (SCA2) at a benchmark quotient greater than 0.1 , but neither detection exceeded the HBSL of $1 \mu \mathrm{g} / \mathrm{L}$.

\section{Factors Affecting Occurrence of Frequently Detected Pesticides}

In the Valley and Ridge aquifers, the most frequently detected pesticides (atrazine, deethylatrazine, simazine, metolachlor, prometon, and tebuthiuron) were detected in at least 10 percent of all samples analyzed regardless of reporting level (table 17). The prevalence of these pesticides in the environment reflects a combination of influences that determine the rate and spatial extent of application, the exposure of groundwater systems to entry, and the persistence of compounds once they are in the system.

The persistence of pesticides in the environment in their original form is affected by decay rates and solubility. Kerle and others (1996) separated pesticides into three categories based on rates of decay - persistent pesticides with typical soil half-lives of more than 100 days, moderately persistent pesticides with typical soil half-lives of 30 to 100 days, and non-persistent pesticides with typical soil half-lives of less than 30 days. Pesticides with low solubility (hydrophobic pesticides) as indicated by high soil-water partitioning coefficients $\left(\mathrm{K}_{\mathrm{oc}}\right)$ are likely to bind to soil particles and accumulate in soils, and highly soluble (hydrophilic) pesticides with low $\mathrm{K}_{\mathrm{oc}}$ are more likely to be transported to aquifers or streams as solutes. Fuhrer and others (2004) placed the hydrophobic/ hydrophilic $\mathrm{K}_{\mathrm{oc}}$ threshold at 300 milliliters per gram $(\mathrm{mL} / \mathrm{g})$. Any pesticide released in the environment will remain for a period of time and undergo transport or degradation to some degree. The pesticides with the greatest potential for transport are those that are both highly soluble in water and relatively persistent (Kerle and others, 1996). The potential for pesticide transport through soil to groundwater was approximated by Vogue and others (1994) in a pesticide movement rating based on pesticide half-life and $\mathrm{K}_{\mathrm{oc}}$ in soil (table 19).

In general, detection frequencies for common pesticides in water samples from sites in the Valley and Ridge aquifers are consistent with the hypothesis that high-use pesticides with high movement ratings will be detected more frequently than low-use and low movement rating pesticides. Chlorpyrifos was among the 15 pesticides most frequently applied within the Valley and Ridge (table 20) (Naomi Nakagaki, U.S. Geological Survey, written commun., 2009), but it was not detected in a single groundwater sample (table 17). As might be expected, chlorpyrifos is only a moderately persistent to non-persistent compound (short half-life) of low solubility and very low movement rating (table 19). Commensurately, atrazine, simazine, and metolachlor, which also are widely used in the Valley and Ridge (table 20), have high movement

Table 19. Physical properties of selected pesticides detected in the Valley and Ridge aquifers, 1993-2002.

$\left[\mathrm{K}_{\mathrm{oc}}\right.$, soil-water partition coefficient; $\mathrm{mL} / \mathrm{g}$, milliliters per gram; $\mathrm{mg} / \mathrm{L}$, milligrams per liter]

\begin{tabular}{|c|c|c|c|c|}
\hline \multirow[b]{2}{*}{ Pesticide compound } & \multicolumn{4}{|c|}{ Physical properties $^{1}$} \\
\hline & $\begin{array}{c}\text { Pesticide movement } \\
\text { rating }\end{array}$ & $\begin{array}{c}\text { Soil half-life } \\
\text { (days) }\end{array}$ & $\begin{array}{c}\log K_{o c} \\
\left(K_{o c} \text { in } \mathrm{mL} / g\right)\end{array}$ & $\begin{array}{c}\text { Solubility } \\
\text { (mg/L) }\end{array}$ \\
\hline Atrazine & High & 60 & 2 & 33 \\
\hline Deethylatrazine $^{2}$ & $\operatorname{High}^{3}$ & 170 & 1.9 & 3,200 \\
\hline Simazine & High & 60 & 2.11 & 6.2 \\
\hline Metolachlor & High & 90 & 2.3 & 530 \\
\hline Prometon & Very high & 500 & 2.18 & 720 \\
\hline Tebuthiuron & Very high & 360 & 1.9 & 2500 \\
\hline Chlorpyrifos & Very low & 30 & 3.78 & 0.4 \\
\hline
\end{tabular}

${ }^{1}$ Soil half-life, $\log \mathrm{K}_{\mathrm{oc}}$, and solubility for all pesticides except deethylatrazine were obtained from Vogue and others (1994).

${ }^{2}$ Soil half-life and $\log \mathrm{K}_{\mathrm{oc}}$ for deethylatrazine were obtained from Mackay (2001); solubility for deethylatrazine was obtained from the U.S. National Library of Medicine (2008).

${ }^{3}$ A pesticide movement rating was not determined for deethylatrazine (Kerle and others, 1996). Deethylatrazine is a breakdown product of atrazine, so the pesticide movement rating for atrazine was used for comparison. 
Table 20. Summary of pesticide compounds most frequently applied in basins in the Valley and Ridge aquifers.

[Compound names in bold were included in the 47 pesticides analyzed in the current study]

\begin{tabular}{|c|c|c|c|c|}
\hline \multirow[b]{2}{*}{ Rank $^{2}$} & \multicolumn{4}{|c|}{ Pesticide compounds most frequently applied in the Valley and Ridge aquifer system ${ }^{1}$} \\
\hline & $\begin{array}{c}\text { Delaware } \\
\text { River Basin }\end{array}$ & $\begin{array}{c}\text { Susquehanna } \\
\text { River Basin }\end{array}$ & $\begin{array}{c}\text { Potomac } \\
\text { River Basin }\end{array}$ & $\begin{array}{l}\text { Tennessee } \\
\text { River Basin }\end{array}$ \\
\hline 1 & Sulfur & Metolachlor & Oil & Methyl Bromide \\
\hline 2 & Metolachlor & Atrazine & Sulfur & $1,3-\mathrm{D}$ \\
\hline 3 & Atrazine & Oil & Metolachlor & Oil \\
\hline 4 & Oil & Pendimethalin & Atrazine & Maleic Hydrazide \\
\hline 5 & Alachlor & Alachlor & Captan & Atrazine \\
\hline 6 & Captan & Captan & Alachlor & 2,4-D \\
\hline 7 & Pendimethalin & Cyanazine & $2,4-\mathrm{D}$ & Captan \\
\hline 8 & Glyphosate & Sulfur & Ziram & Acephate \\
\hline 9 & Cyanazine & Chlorpyrifos & Mancozeb & Chlorpyrifos \\
\hline 10 & Mancozeb & Methyl Bromide & Simazine & Ziram \\
\hline 11 & Chlorothalonil & Glyphosate & Chlorpyrifos & Sulfur \\
\hline 12 & Maneb & Simazine & Azinphos-Methyl & Alachlor \\
\hline 13 & $2,4-\mathrm{D}$ & Mancozeb & Metiram & Metolachlor \\
\hline 14 & Cryolite & Dimethoate & Pendimethalin & Chloropicrin \\
\hline 15 & Chlorpyrifos & 2,4-D & Glyphosate & Carbaryl \\
\hline
\end{tabular}

${ }^{1}$ Naomi Nakagaki, U.S. Geological Survey, written commun., 2009.

${ }^{2}$ Pesticide compounds are sorted in descending order of amount of active ingredient applied in the river basin.

ratings and are among the most frequently detected pesticides (table 17). In contrast, tebuthiuron, though not among the 15 most frequently applied pesticides, was frequently detected, perhaps because of its high persistence and solubility (table 19).

Dissolved oxygen concentrations were positively correlated to all of the most frequently detected pesticides except tebuthiuron (table 21). The apparent persistence of compounds such as atrazine, deethylatrazine, simazine, and metolachlor in the presence of oxygen suggests relatively young water in which microbial oxidation is unable to degrade these compounds faster than they are replaced in recharge (Kaufman and Kearney, 1970; Barbash and Resek, 1996; Seybold and Mersie, 1999; Lindsey and others, 2009). Although atrazine and deethylatrazine were detected frequently in samples that were oxic, the degradation characteristics can be seen by comparing the deethylatrazine fraction among redox groups. The fraction, calculated by dividing the deethylatrazine concentration in moles by the molar sum of atrazine and deethylatrazine, is an indicator of how much of the total product has degraded to a given daughter product. Deethylatrazine fractions were higher in oxic samples (50 percent) than in mixed and anoxic samples (40 percent). The higher deethylatrazine fraction in the oxic samples is an indication that more degradation is likely taking place in the oxic parts of the aquifer; however, detection frequency is still high in those areas because oxic water was also likely to be receiving a regular influx of atrazine in recharge from overlying agricultural lands.

Strong positive correlations were observed between nitrate and all of the most frequently detected pesticides except tebuthiuron (table 21). Not surprisingly, agricultural land use (row crop, hay, and pasture) also was positively correlated to concentrations of the agricultural pesticides atrazine (including its degradate deethylatrazine) and metolachlor. Nitrate and agricultural pesticides generally co-occur because both are applied to crops. Concentrations of the general-use pesticides simazine, prometon, and tebuthiuron were not correlated as strongly to agricultural land use, and concentrations of all the frequently detected pesticides except tebuthiuron were negatively correlated with forested land use. Prometon and tebuthiuron concentrations were weakly correlated with urban land use.

Overall, soil type and land use appear to have a dominant influence on the presence of pesticides in groundwater in the Valley and Ridge. Pesticide concentrations were strongly and negatively correlated to percent sand and percent forest. Based on soil properties alone, pesticide transport should be enhanced in sandy soils due to high inherent permeability 
Table 21. Summary of Spearman's rho correlations between frequently detected pesticide concentrations and selected site-specific and source variables in groundwater in the Valley and Ridge aquifers, 1993-2002.

[Spearman's rho only shown for variables statistically correlated to pesticide concentrations at the 95-percent confidence level (probabilities less than 0.05); NS, correlation not significant at the 95-percent confidence level (probabilities greater than 0.05); No significant correlations were found between pesticide concentration and normalized lateral position. See table 22 for correlations that were observed between pesticide concentrations and normalized lateral position in selected topographic sections.]

\begin{tabular}{|c|c|c|c|c|c|c|}
\hline Variable & Atrazine & Deethylatrazine & Simazine & Metolachlor & Prometon & Tebuthiuron \\
\hline \multicolumn{7}{|c|}{ Site-specific variables } \\
\hline Dissolved oxygen & 0.49 & 0.52 & 0.35 & 0.3 & 0.19 & NS \\
\hline Nitrate & 0.81 & 0.81 & 0.68 & 0.57 & 0.49 & NS \\
\hline Percent sand & -0.72 & -0.71 & -0.64 & -0.52 & -0.52 & -0.2 \\
\hline Percent silt & 0.5 & 0.5 & 0.55 & 0.44 & 0.35 & NS \\
\hline Percent clay & 0.35 & 0.33 & 0.21 & 0.19 & 0.24 & 0.22 \\
\hline Well depth below land surface & -0.14 & NS & -0.21 & -0.17 & NS & NS \\
\hline Water level & 0.18 & 0.17 & NS & NS & NS & NS \\
\hline \multicolumn{7}{|c|}{ Source variables } \\
\hline Row crop, hay, pasture & 0.52 & 0.54 & 0.41 & 0.24 & 0.15 & -0.18 \\
\hline Forest & -0.63 & -0.64 & -0.58 & -0.48 & -0.46 & NS \\
\hline Urban & NS & -0.12 & NS & NS & 0.21 & 0.26 \\
\hline 1990 population density & 0.24 & 0.21 & 0.28 & 0.35 & 0.43 & 0.19 \\
\hline
\end{tabular}

and low organic carbon. This effect would be reversed in clay soils (Barbash and Resek, 1996), so one might expect a positive correlation of pesticide concentration to sand content. A similar negative correlation to sand content has been observed in other studies (Lindsey and others, 2006; Lindsey and others, 2009), where it was attributed to the possible effects of macropore flow and karst features that allow contaminated water to bypass clay soils. However, the strong correlation of pesticides to nitrate when taken in context of the relatively strong correlations of nitrate to agricultural and sandy soils (tables 15 and 16) suggests a conceptual model in which agricultural pesticides are preferentially applied to agricultural lands which in turn are preferentially located on non-sandy soils (silt-clay).

Still, differences between agricultural networks (PCA and PSA) maintain the possibility that soils and the inherent susceptibility of bedrock to contamination play some role in pesticide occurrence in groundwater of the Valley and Ridge. Atrazine, deethylatrazine, and simazine were all detected in a higher percentage of the samples and at higher concentrations from agricultural and urban land-use areas overlying carbonate-rock aquifers than in samples from any other combination of land use and aquifer type (fig. 24). In contrast, metolachlor and prometon detection frequencies and concentrations were higher in samples from urban areas than in samples from agricultural areas in carbonate-rock aquifers. Concentrations of atrazine were significantly lower in water samples from sites in siliciclastic-rock aquifers, regardless of land use (fig. 24). Tebuthiuron detections were too few in number to evaluate the effects of the combined land use/aquifer setting on concentrations.

Across the spectrum from ridge to stream, landscape position (NLP) does not appear to play a defining role in occurrence of frequently detected pesticides (table 22). Concentrations of the six most frequently detected pesticides were not correlated with NLP when viewed over the whole range of NLP. However, concentrations of atrazine and deethylatrazine may be somewhat correlated to NLP when considered only within the upper or lower topographic sections for carbonaterock aquifers or lower topographic section for siliciclasticrock aquifers; generally positive correlations are in the upper section, and negative correlations are in the lower section. Significant negative correlations were observed for simazine concentrations in only the lower section in the carbonate-rock aquifers and for metolachlor concentrations in only the lower section in the siliciclastic-rock aquifers. These correlations suggest the effect of relatively recent recharge in the lower topographic section as indicated by correlations with dissolved oxygen noted earlier (tables 12 and 21). 

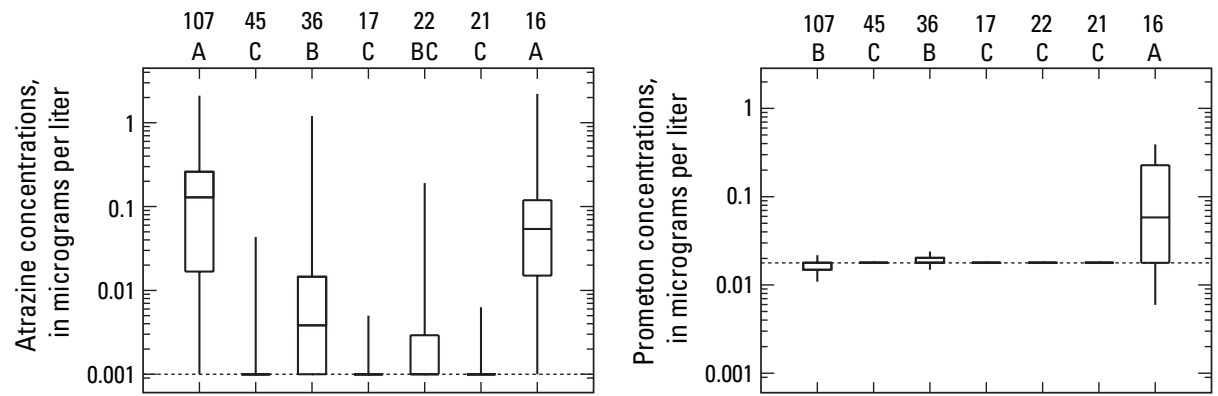

EXPLANATION

45 Number of samples

A Statistical group from nonparametric Tukey's test

Maximum value

75th percentile Median

25th percentile

Minimum value

Most common

laboratory reporting level for individual

pesticide

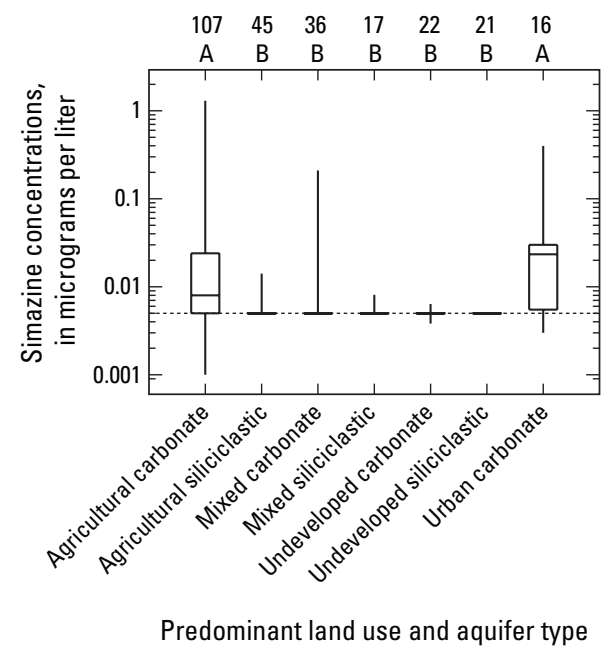

Figure 24. Distribution of atrazine, deethylatrazine, simazine, prometon, and metolachlor concentrations by combined land use/aquifer setting in the Valley and Ridge aquifers, 1993-2002. 
Table 22. Summary of Spearman's rho correlations between frequently detected pesticide concentrations in groundwater and normalized lateral position by aquifer type in the Valley and Ridge aquifers, 1993-2002.

[Spearman's correlation test results only shown for variables statistically correlated to pesticide concentrations at the 95-percent confidence level (probabilities less than 0.05); NS, correlation not significant at the 95-percent confidence level (probabilities greater than 0.05 ); ND, no detections of this compound; n, number of observations; NLP, normalized lateral position]

\begin{tabular}{|c|c|c|c|c|}
\hline Pesticide & All & $\begin{array}{c}\text { Upper } \\
\text { topographic } \\
\text { section } \\
\text { NLP less than } 0.40 \\
\end{array}$ & $\begin{array}{c}\text { Middle } \\
\text { topographic } \\
\text { section } \\
\text { NLP } 0.40 \text { to } 0.70 \\
\end{array}$ & $\begin{array}{c}\text { Lower } \\
\text { topographic } \\
\text { section } \\
\text { NLP greater than } 0.70 \\
\end{array}$ \\
\hline \multicolumn{5}{|c|}{ Carbonate aquifers (springs included) } \\
\hline Atrazine & NS & $\begin{array}{c}0.38 \\
(\mathrm{n}=34)\end{array}$ & NS & $\begin{array}{c}-0.22 \\
(\mathrm{n}=83)\end{array}$ \\
\hline Deethylatrazine & NS & $\begin{array}{c}0.39 \\
(\mathrm{n}=34)\end{array}$ & NS & $\begin{array}{l}-0.25 \\
(\mathrm{n}=83)\end{array}$ \\
\hline Simazine & NS & NS & NS & $\begin{array}{c}-0.3 \\
(\mathrm{n}=83)\end{array}$ \\
\hline Metolachlor & NS & NS & NS & NS \\
\hline Prometon & NS & NS & NS & NS \\
\hline Tebuthiuron & NS & NS & NS & NS \\
\hline \multicolumn{5}{|c|}{ Siliciclastic aquifers } \\
\hline Atrazine & NS & NS & NS & $\begin{array}{c}-0.33 \\
(\mathrm{n}=42)\end{array}$ \\
\hline Deethylatrazine & NS & NS & NS & NS \\
\hline Simazine & NS & ND & ND & NS \\
\hline Metolachlor & NS & ND & NS & $\begin{array}{l}-0.38 \\
(\mathrm{n}=42)\end{array}$ \\
\hline
\end{tabular}

\section{Other Pesticides Analyzed}

High performance liquid chromatography (HPLC) was used to analyze a subset of samples from 242 sites for additional pesticides; relatively few pesticides were detected during this analysis (table 23, at end of report). The herbicides diuron, bentazon, and dichlobenil, for example, were detected at only 8,4 , and 2 sites, respectively. Diuron was detected only in samples from carbonate-rock aquifers and mostly in urban settings. Bentazon was detected in samples from three out of four siliciclastic-rock aquifer networks. Other pesticides, including 2,4-D, acifluorfen, bromacil, dicamba, fenuron, linuron, norflurazon, and oryzalin were each detected once. All of the pesticides analyzed using HPLC tend to be less mobile in groundwater, which partly accounts for their relatively low detection rates.

Analyses for 25 other pesticides, pesticide degradation products, and organic compounds using HPLC/MS for samples from 30 wells in the DSM network and samples from 16 wells in the PCA network indicate more frequent occurrence of pesticide degradation products in carbonate- than in siliciclastic-rock aquifers. Atrazine and simazine degradation products didealkyl atrazine (CAAT), deisopropylatrazine/DIA (CEAT), and hydroxyatrazine (OIET) were detected in 38 , 56 , and 63 percent of samples, respectively, in carbonate-rock aquifers and in 13, 7, and 3 percent of samples, respectively, in siliciclastic-rock aquifers. This pattern of greater detection frequency in the carbonate-rock aquifers is similar to the pattern seen in detections of other pesticides.

\section{Volatile Organic Compounds}

Volatile organic compounds (VOCs) include a wide range of natural and synthetic carbon-based compounds that have high vapor pressure and relatively low solubility in water. VOCs are used in industrial, commercial, and domestic applications and can enter the groundwater as liquid through spills and leaks or by atmospheric deposition. VOCs typically found in groundwater include industrial solvents, fuel hydrocarbons and oxidizers, fumigants, organic synthesis compounds, refrigerants, and disinfection byproducts (trihalomethanes) (Carter and others, 2007). 


\section{Occurrence and Distribution of VOCs}

VOCs are the most commonly found contaminant class associated with industrial and commercial sites, dumps, landfills, hazardous waste facilities, and military bases (Zogorski and others, 2006) and are widespread wherever human activities occur. Historically, many waste chemicals were disposed of indiscriminately, and the widespread use of VOCs has resulted in considerable mass of material released to the environment. Localized releases of VOCs occur from many sources, including leakage from storage tanks, direct application of pesticides containing VOCs (Barbash and Resek, 1996), septic systems, and leaking sewer systems. VOCs also are released to the atmosphere through engine exhausts, aerosol sprays, leakage of refrigerants, and application of fumigants and pesticides. Trihalomethanes (THMs) are frequently associated with chlorinated water and chlorinated cleaning products.

The VOCs detected in water samples from sites in the Valley and Ridge aquifers were a mixture of THMs, solvents, fuel-related products, and organic synthesis compounds (table 24, at end of report). At a detection level of $0.2 \mu \mathrm{g} / \mathrm{L}$, the 10 most frequently detected VOCs were chloroform, tetrachloroethene (PCE), 1,1,1-trichloroethane (TCA), chloromethane, styrene, carbon disulfide, methyl tert-butyl ether (MTBE), trichloroethene (TCE), toluene, and bromodichloromethane. Analyses for carbon disulfide were only added after April 1996. At this detection level $(0.2 \mu \mathrm{g} / \mathrm{L})$, VOCs were unevenly distributed (fig. 25) and were mostly in samples from the urban network (SCU) where THMs were most commonly detected (at 55 percent of sites) (table 25). VOCs were not detected in samples from sites in two Susquehanna networks (SSM and SCA2) and were detected at less than 17 percent of sites in each of the remaining networks. The presence of VOCs by group varied from a single group of compounds (solvents) in one agricultural network (SCA3) to the presence of four groups (THMs, gasoline compounds, solvents, and organic synthesis compounds) in the SCU and TCM networks.

The presence of the THM chloroform in groundwater may reflect its use as a solvent or its use in various industrial processes but also may be attributed to chlorinated water entering aquifers from multiple sources (Zogorski and others, 2006). The relatively frequent detection of THMs in samples from sites in the Valley and Ridge aquifers is consistent with a nationwide study by Zogorski and others (2006) that reported THMs in 5.3 percent of domestic well samples and in 15 percent of public water-supply samples. In the Valley and Ridge, 9.5 percent of samples had detects above $0.2 \mu \mathrm{g} / \mathrm{L}$ (table 25). Chloroform was the most frequently detected THM in the group and the most frequently detected VOC overall (at 9.5 percent of sites) (table 24), which is also consistent with national results (5.2 percent of domestic wells and 11.4 percent of public wells; Zogorski and others, 2006). THMs are often byproducts of the chlorination of drinking water and wastewater and the disinfection of wells (Zogorski and others, 2006) and may be formed in wastewater treatment and septic systems where chlorine is present. The high numbers of THMs present in samples from sites in the urban network (SCU) may reflect a combination of aging infrastructure, leaking sewer systems, and local industrial processes.

Solvents, mostly chlorinated compounds, were the second most commonly detected group of VOCs in the Valley and Ridge aquifers. Overall, nine solvents were detected in 9 percent of the groundwater samples (table 25). This is generally consistent with national results where solvents were detected in 4.9 percent of domestic well samples and 9.9 percent of public water-supply samples (Zogorski and others, 2006). Three of 9 solvents detected were among the 10 VOCs most frequently detected in samples from the Valley and Ridge aquifers. After chloroform, the chlorinated solvent TCA was the second most frequently detected VOC followed by PCE. TCE was eighth in order of detection frequency.

Gasoline-related compounds were the third most commonly detected group of VOCs, with detections above $0.2 \mu \mathrm{g} / \mathrm{L}$ in 6.8 percent of samples (table 25). A total of 23 gasoline compounds were analyzed (only 14 prior to 1996), 10 of which were detected at levels above $0.2 \mu \mathrm{g} / \mathrm{L}$ in the urban network (SCU) where 35 percent of the samples contained from 1 to 9 gasoline-related compounds (table 25). Among the compounds associated with gasoline, collectively known as BTEX compounds, are benzene, toluene, ethylbenzene, and various xylene isomers $(o-, m$ - and $p$-xylene, which are summed together as total xylene). Benzene, toluene, and total xylene were detected in 1.1 percent of samples, and ethylbenzene was detected in 0.5 percent of samples (table 24).

MTBE, a common fuel oxygenate, was the second most commonly detected VOC (above $0.2 \mu \mathrm{g} / \mathrm{L}$ ) in the Valley and Ridge aquifers (5.9 percent of samples; table 24) and nationally ( 3 percent in private well samples and 5 percent in public well samples; Zogorski and others, 2006). MTBE was detected in 35 percent of samples from urban network wells (SCU). MTBE also was detected in 10 percent of samples from DSM wells, which were located in a high MTBE-use area as defined by the Federal Reformulated Gasoline Program (U.S. Environmental Protection Agency, 1990, 2007). MTBE was detected in one sample from the southern part of the Valley and Ridge (TCS network) at a site downgradient from fuel storage tanks and close to railroad tracks where MTBE was transported.

Organic synthesis compounds are used as precursors in the manufacturing of other organic compounds. This was the least commonly detected group of VOCs in the Valley and Ridge aquifers, with only 0.5 percent of samples exceeding $0.2 \mu \mathrm{g} / \mathrm{L}$ (table 25). Carbon disulfide and 1,3,5-trimethylbenzene were each detected once above $0.2 \mu \mathrm{g} / \mathrm{L}$; however, carbon disulfide was detected seven times at concentrations below $0.2 \mu \mathrm{g} / \mathrm{L}$ (table 24).

Overall, the detection of one VOC at a site increased the likelihood of finding others. About 18 percent of samples from the Valley and Ridge aquifers contained one or more VOCs (detected above $0.2 \mu \mathrm{g} / \mathrm{L}$ ), about 8 percent of samples contained two or more VOCs, about 5 percent of samples contained three or more VOCs, and about 3 percent of samples 


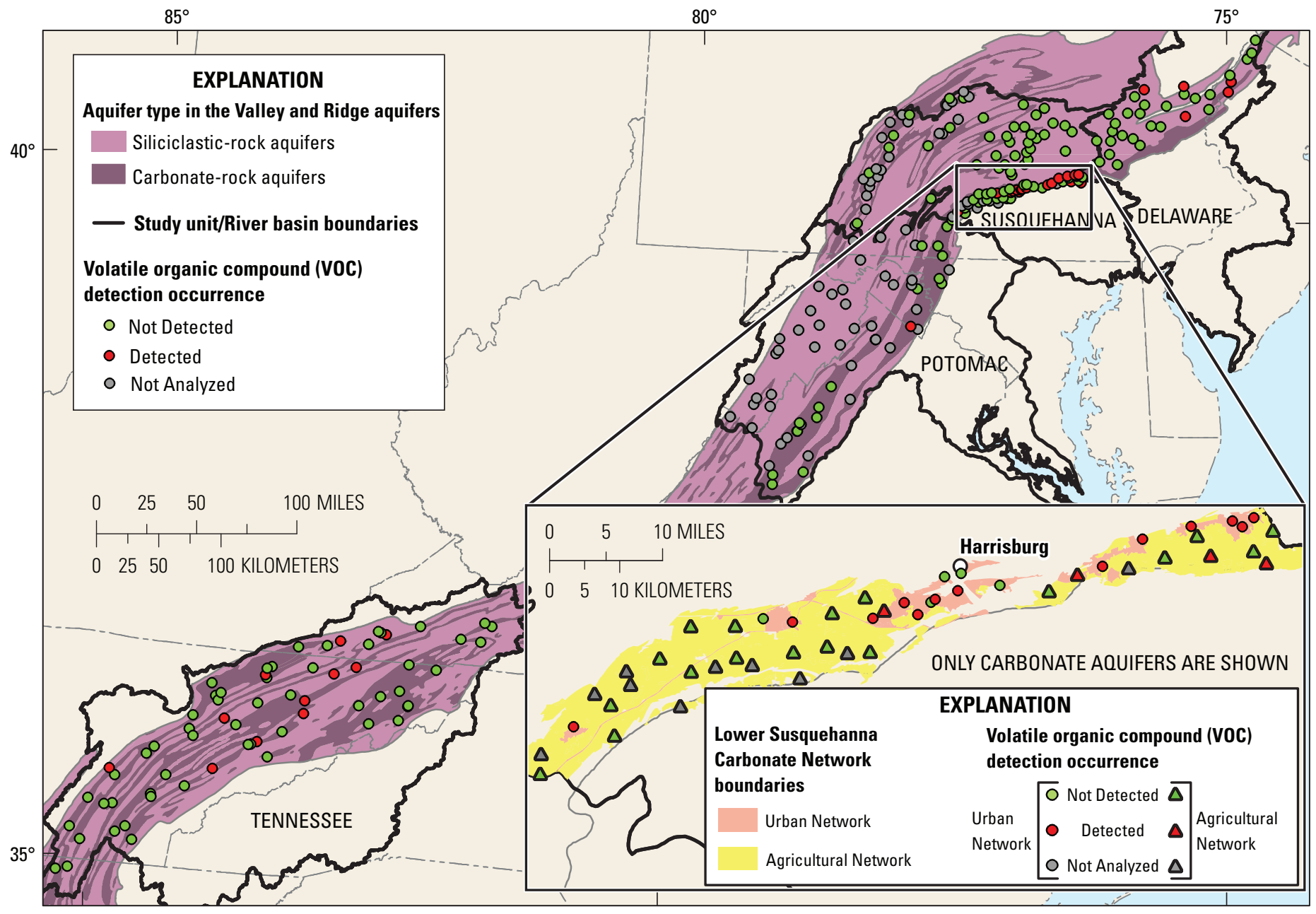

Base from U.S. Bureau of the Census, 1990a, 1:500,000 to 1:5,000,000

Universal Transverse Mercator projection, Zone 18N

Horizontal datum: North American Datum of 1983 (NAD 83)
Populated places from U.S. Bureau of the Census, 1990b Agricultural and urban network boundaries from Siwiec and others, 1997 Principal aquifers from U.S. Geological Survey, 2003 NAWQA study units from Hitt and Nakagaki, 2006

Figure 25. Volatile organic compounds detected at a concentration greater than 0.2 micrograms per liter in the Valley and Ridge aquifers, 1993-2002. 


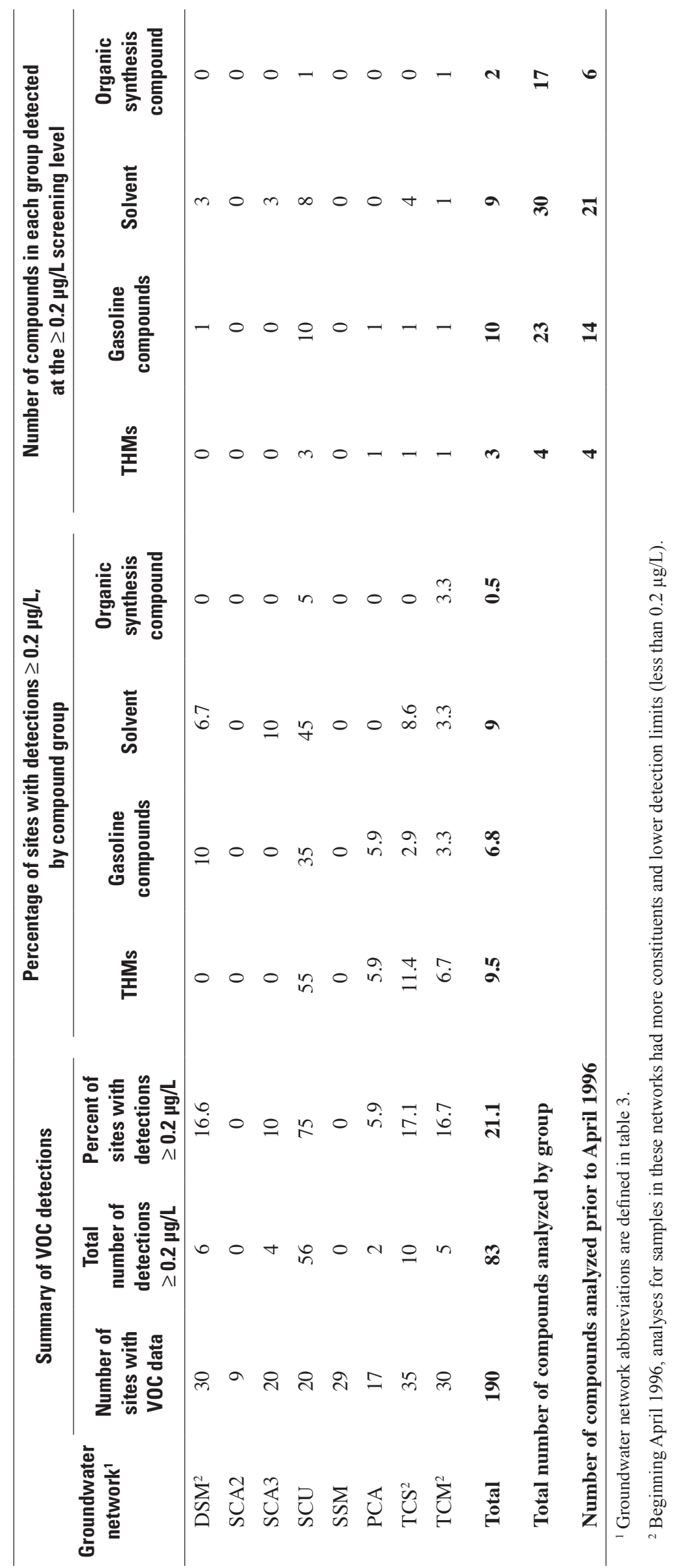


contained four or more VOCs (fig. 26). One sample from a well in the urban network (SCU) contained 14 detectable VOCs. The percentage of samples in the Valley and Ridge aquifers containing one or more VOCs was similar to national findings. In all NAWQA studies, 19 percent of samples contained one or more VOCs (Zogorski and others, 2006), and 20 percent of the samples from carbonate-rock aquifers contained one or more VOCs (Lindsey and others, 2009).

\section{Assessment of Potential Effects of VOCs on Human Health}

Benchmark quotients for VOCs in samples from the Valley and Ridge aquifers indicate some developing issues but no immediate concerns related to human health. Currently (2010), MCLs have been established for 20 of the 87 VOCs analyzed as part of this study, and HBSL benchmarks have been established for 25 of the 87. MCLs or HSBLs have not been established for VOCs where data are insufficient to evaluate human-health effects. None of the VOCs detected exceeded USEPA MCLs (U.S. Environmental Protection Agency, 2006) or HBSLs (Toccalino and others, 2008). HBSL benchmark quotients for five VOCs were within the range of 0.1 to 1.0 , indicating that concentrations approached levels of potential concern for human health (table 24, fig. 27). In particular, benchmark quotients for chloroform, PCE, TCE, benzene, and carbon tetrachloride, exceeded 0.1 in 0.5 to 2.1 percent of samples. The MTBE concentration at one site in the urban network (SCU) exceeded a taste and odor advisory guideline of 20 to $40 \mu \mathrm{g} / \mathrm{L}$ established by the USEPA (U.S. Environmental Protection Agency, 1997).

\section{Factors Affecting Occurrence of VOCs}

The occurrence of VOCs in groundwater of the Valley and Ridge aquifers is generally affected by the same basic processes and conditions associated earlier in this report with
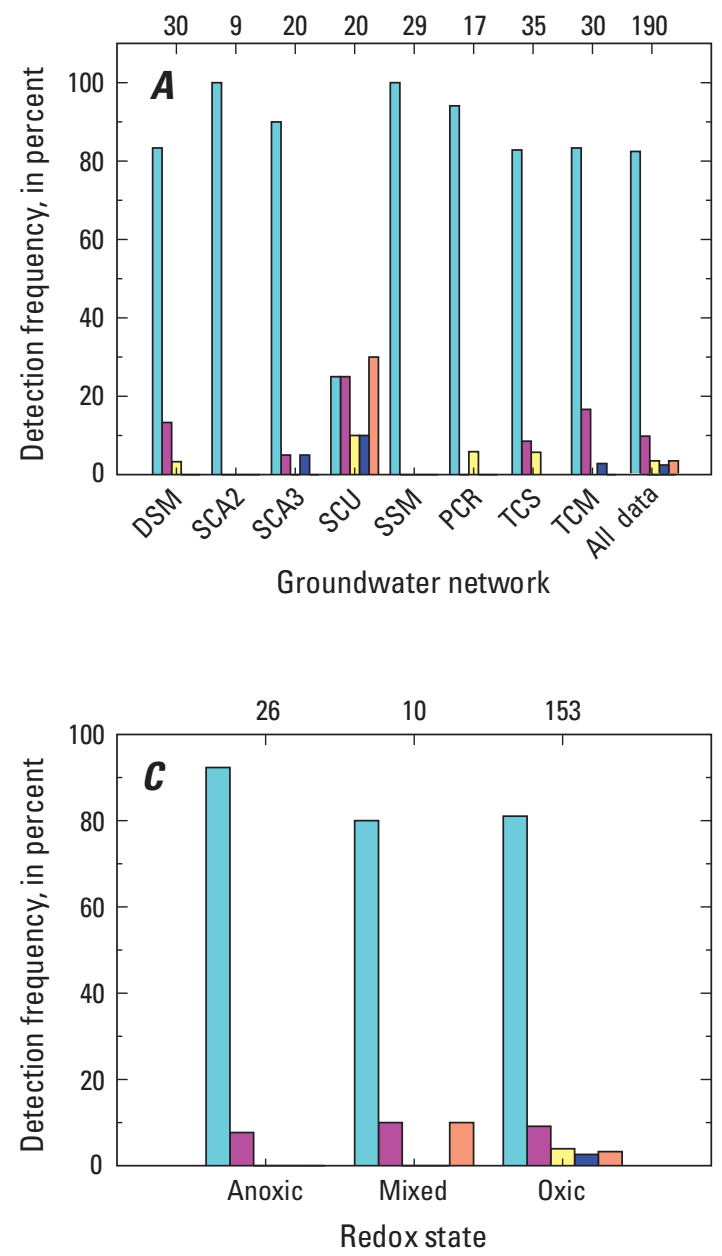
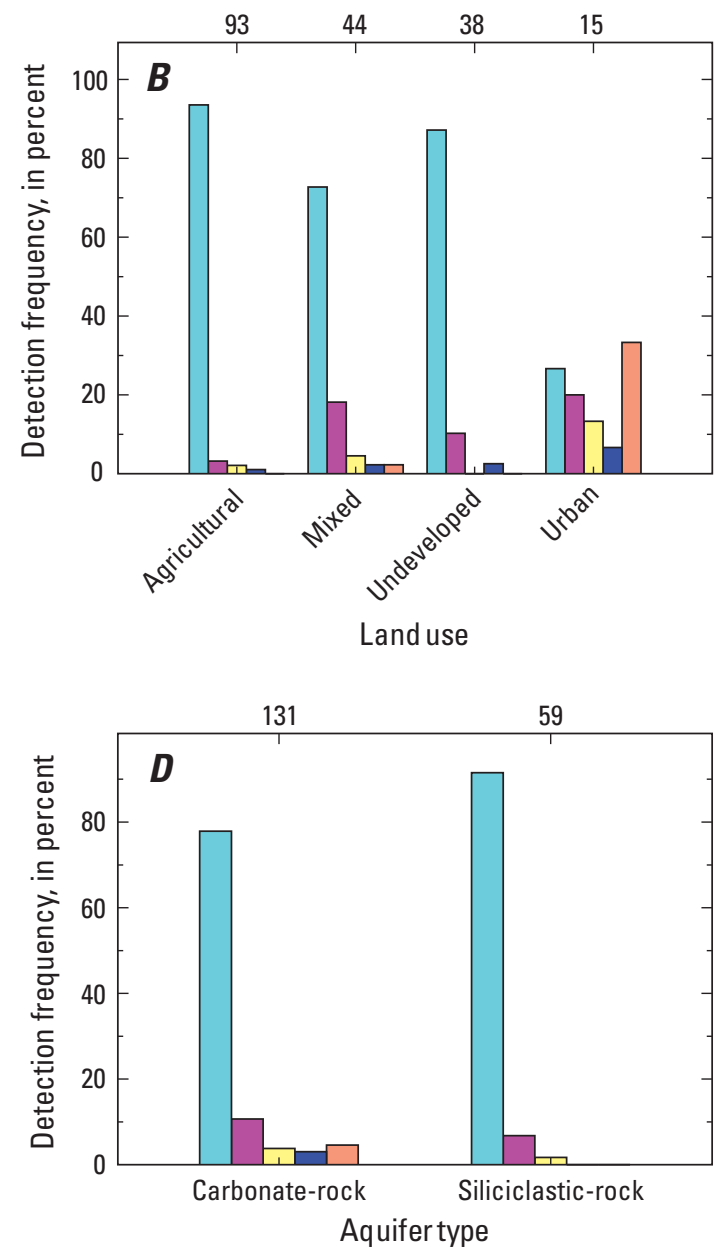

\section{EXPLANATION}

30 Number of samples Number of VOCs detected per sample

$\square$ None

1 detected

$\square 2$ detected

3 detected

$\square 4$ or more detected

DSM Groundwater network code, see table 3 for network abbreviation codes

Figure 26. Detection frequency for samples with volatile organic compounds (VOCs) detected at the 0.2-microgram per liter assessment level by, $A$, groundwater network and, $B$, land-use classification and by, $C$, redox state and, $D$, aquifer type for samples in the Valley and Ridge aquifers, 1993-2002. 

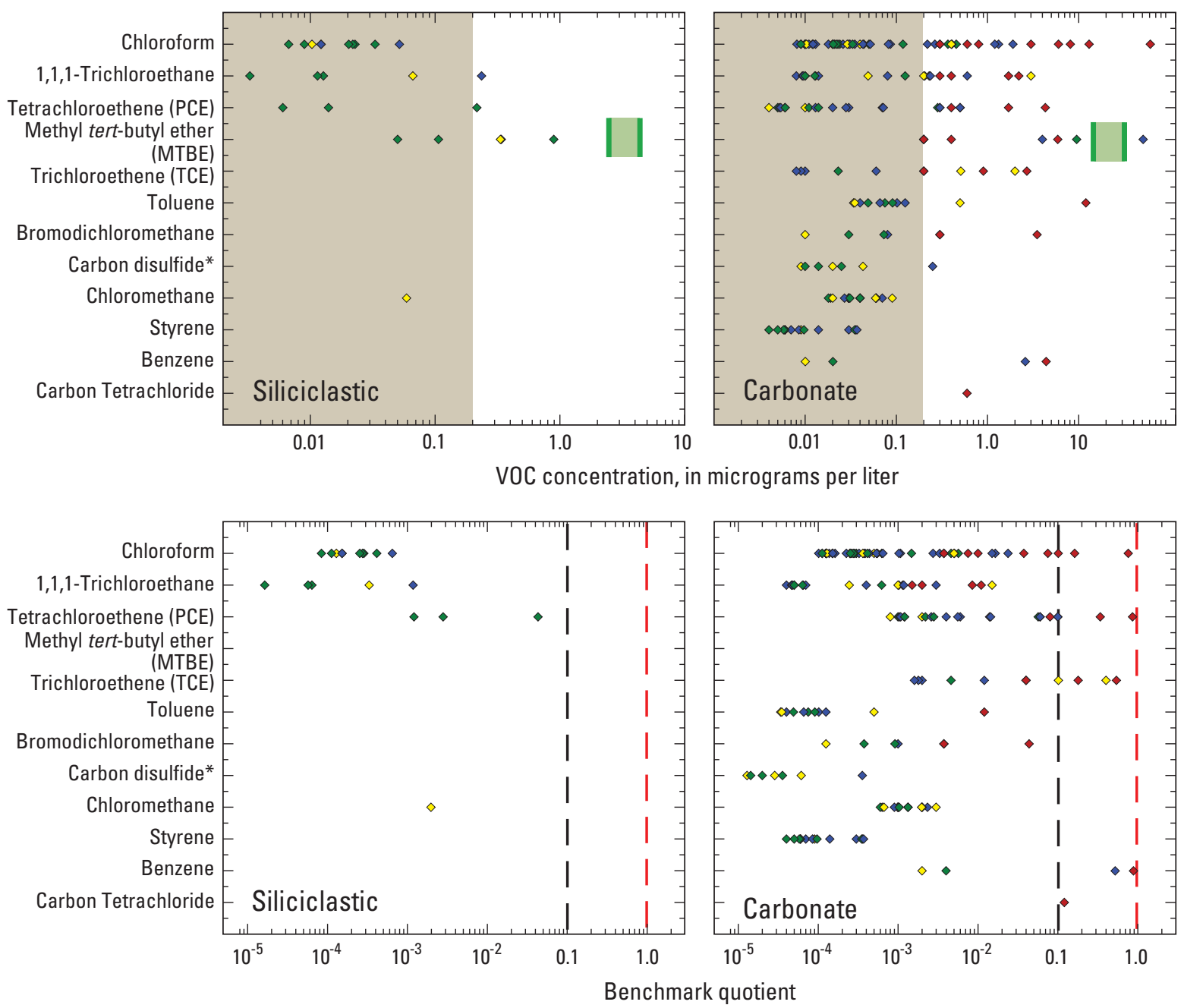

\section{EXPLANATION}

Land Use

$\diamond$ Agricultural

- Mixed

- Undeveloped

- Urban

Benchmark quotient value $(\mathrm{BO})=\frac{\text { Chloroform concentration }}{\text { Chloroform } \mathrm{MCL}=80 \mu \mathrm{g} / \mathrm{L}}$

| Benchmark quotient value of 0.1 -- Values greater than this line are within one order

I of magnitude of an MCL or HBSL

MCL is Maximum Contaminant Level for regulated compounds (U.S. Environmental Protection Agency, 2006).

HBSL is Health-Based Screening Level concentrations for unregulated compounds (Toccalino and others, 2008).

USEPA guidelines for drinking-water advisory range for taste and odor (U.S. Environmental Protection Agency, 1997)

* Carbon disulfide was only measured in half of the samples

Shaded area represents concentrations reported that were less than $0.2 \mu \mathrm{g} / \mathrm{L}$. Samples collected prior to 1996 used $0.2 \mu \mathrm{g} / \mathrm{L}$ as a laboratory reporting limit (LRL); later samples had lower LRLs. Comparisons cannot be made among samples in the shaded area.

Benchmark quotient value of 1.0 -- Values greater than this line would indicate concentrations of potential health concerns

Figure 27. Concentrations and benchmark quotients of the most common volatile organic compounds in various land-use categories in the Valley and Ridge siliciclastic-rock and carbonate-rock aquifers, 1993-2002. 
pesticides: the availability of sources, the chemical persistence of compounds, and the efficiency of transport mechanisms. In a national summary of groundwater quality, the most common factors associated with VOC concentrations in aquifers were the presence of septic systems, urban land, hazardous waste facilities, and gasoline storage sites (Zogorski and others, 2006). The presence of VOCs also was related to well characteristics, soil conditions, and most significantly, dissolved oxygen in groundwater. In a study evaluating groundwater samples from carbonate-rock aquifers in the United States, differences in the detection frequencies for the eight most commonly detected VOCs - chloroform, tetrahydrofuran, toluene, PCE, acetone, methyl ethyl ketone (MEK), MTBE, and TCE-were associated with different land uses and also were affected differently by degree of confinement of the aquifers and redox state of the groundwater (Lindsey and others, 2009).

Of the several factors affecting the occurrence of VOCs in groundwater from the Valley and Ridge aquifers, land use may predominate as an indicator of source availability. The highest percentages of VOC detections above $0.2 \mu \mathrm{g} / \mathrm{L}$ were associated with areas of urban land use in carbonate-rock aquifers. The majority of these detections ( 56 of 83 ) were identified in 20 wells in the urban network (SCU) (table 25); 50 percent of the wells had samples with multiple detections (fig. 26). Chloroform concentrations were significantly and positively correlated to urban land use (tau $\mathrm{b}=0.30$ ) and population density (tau $\mathrm{b}=0.26$ ) using a censored Kendall tau test, and chloroform concentrations were positively correlated to the presence of storage tanks (tau $\mathrm{b}=0.36$ ) and public sewer density (tau $\mathrm{b}=$ 0.26 ) in carbonate-rock aquifers.

A negative correlation of chloroform to dissolved oxygen concentrations in samples from sites in carbonate-rock aquifers using the censored Kendall tau test (alpha $=0.05)$ suggests that chemical processes (redox conditions) and chemical degradation may play a mixed or muted role in VOC occurrence in the Valley and Ridge aquifers (fig. 28, table 26). The ratio of VOC detections in oxic versus anoxic conditions is consistent with national results indicating the persistence of chloroform in oxic conditions and of carbon disulfide in anoxic conditions (fig. 29). However, oxic/anoxic detection ratios for toluene and bromodichloromethane were only about 1:1-lower than that reported in national results (Zogorski and others, 2006). Further, a ratio of 1:1 was higher than expected for toluene, which is known to degrade in oxic conditions. These departures from expectations may in part be caused by the low overall detection frequency of VOCs but may also be related to the fact that the majority of wells sampled for toluene were oxic.

Despite somewhat unbalanced representation with respect to redox conditions, the results from the Valley and Ridge aquifers analyses appear overall to be consistent with results from the national studies of VOCs. Multiple VOC detections greater than $0.2 \mu \mathrm{g} / \mathrm{L}$ also were typically associated with mixed or oxic conditions (fig. 26C). This is consistent with national results where TCA, TCE, PCE, bromodichloromethane, and chloroform concentrations were strongly associated with oxic conditions and methylene chloride and

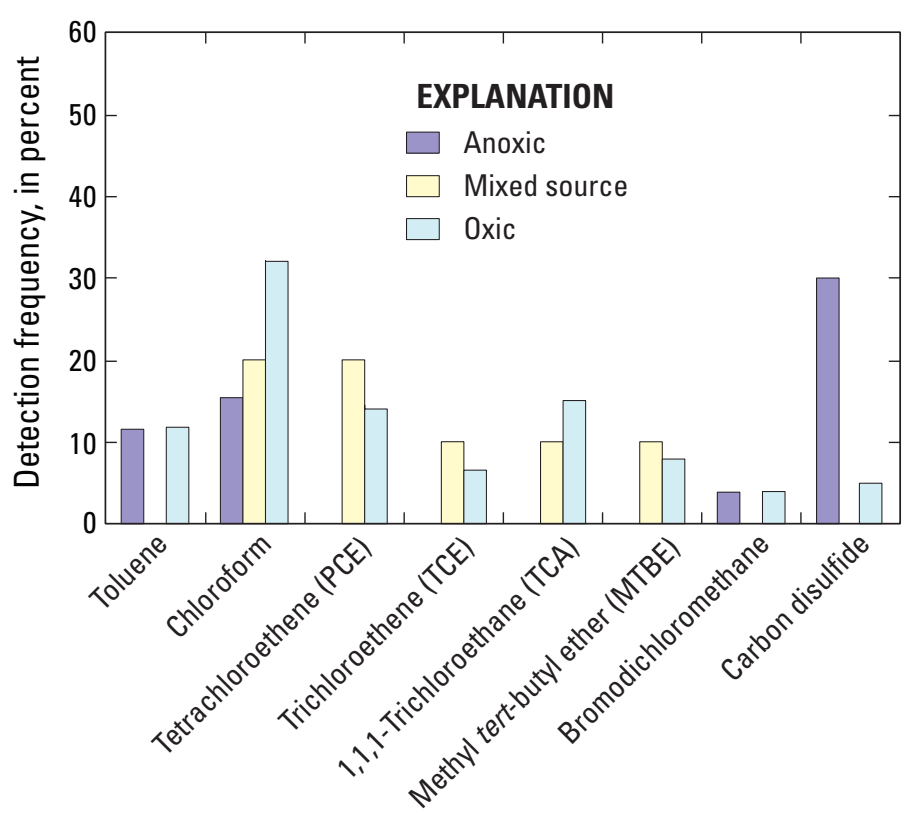

Figure 28. Percentage of detections by redox state for selected volatile organic compounds in the Valley and Ridge aquifers, 1993-2002.

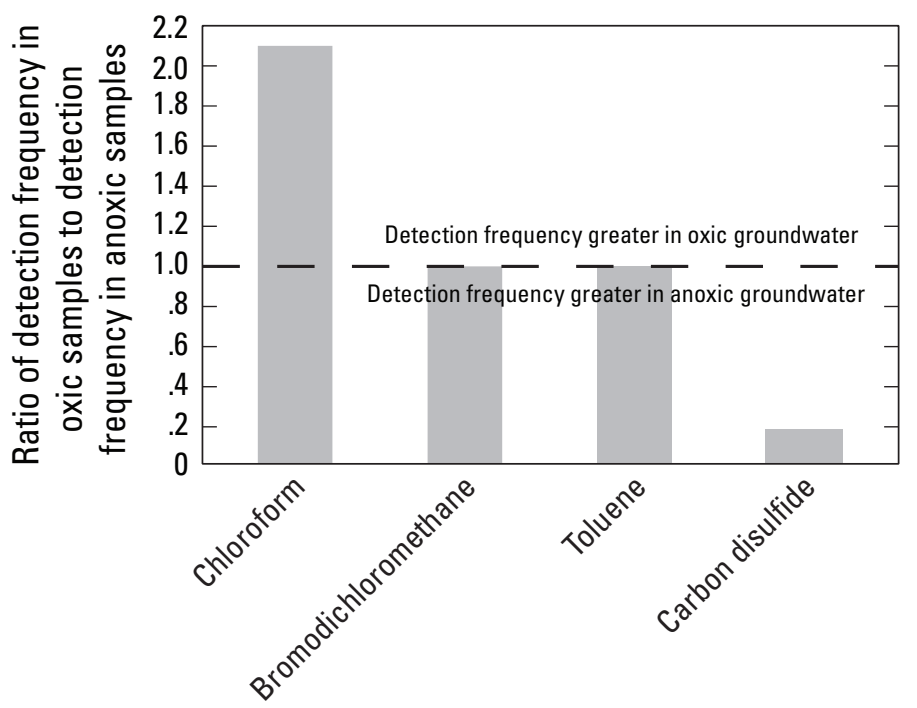

Figure 29. Ratio of detection frequencies in oxic and anoxic samples for selected volatile organic compounds in the Valley and Ridge aquifers, 1993-2002. 
Table 26. Percentage of samples with detections by redox state, and the oxic/ anoxic ratio of detection frequencies for selected volatile organic compounds in groundwater samples from the Valley and Ridge aquifers, 1993-2002.

[--, insufficient number of samples with anoxic conditions to calculate ratio; PCE, tetrachloroethene; TCE, trichloroethene; TCA, 1,1,1-trichloroethane; MTBE, methyl tert-butyl ether]

\begin{tabular}{lrrrc}
\hline \multirow{2}{*}{$\begin{array}{c}\text { Volatile organic } \\
\text { compound }\end{array}$} & \multicolumn{2}{c}{$\begin{array}{c}\text { Detection frequency } \\
\text { (percent) }\end{array}$} & $\begin{array}{c}\text { Ratio of detection } \\
\text { frequency in oxic water } \\
\text { to detection frequency } \\
\text { in anoxic water }\end{array}$ \\
\cline { 2 - 5 } Toluene & 11.5 & 0.0 & 11.8 & 1.02 \\
Chloroform & 15.4 & 20.0 & 32.0 & 2.08 \\
PCE & 0.0 & 20.0 & 14.0 & -- \\
TCE & 0.0 & 10.0 & 6.5 & -- \\
TCA & 0.0 & 10.0 & 15.0 & -- \\
MTBE & 0.0 & 10.0 & 7.9 & -- \\
Bromodichloromethane & 3.8 & 0.0 & 3.9 & 1.02 \\
Carbon disulfide & 30.0 & 0.0 & 4.9 & 0.16 \\
\hline
\end{tabular}

chloromethane concentrations were associated with anoxic conditions (Zogorski and others, 2006). Generally, oxic conditions prevailed (81 percent of wells) across the Valley and Ridge aquifers, and anoxic conditions were concentrated in siliciclastic-rock aquifers (70 percent of the total anoxic samples). Where VOCs were detected in samples from siliciclastic-rock aquifers, the samples were always oxic. Conversely, where VOCs were detected in anoxic samples, those samples were always from wells in carbonate-rock aquifers.

The relatively high detection frequency of chlorinated solvents may be partly explained by the persistence and transport properties of these compounds. Chlorinated solvents have relatively long half-lives in groundwater compared to other VOCs and may be relatively persistent. With specific densities greater than 1.0, chlorinated solvents are denser than water, move downward through aquifers, and are resisted only by capillary pore pressure. In karst aquifers with enlarged conduits, chlorinated solvents can migrate to great depths as dense non-aqueous phase liquids (DNAPLs) (Wolfe and others, 1997; Loop and White, 2001) where they may provide a continuous source of dissolved-phase chlorinated solvents in groundwater. For some highly chlorinated molecules, such as PCE, degradation may produce other chlorinated solvents, such as TCE. The degradation of PCE to TCE occurs preferentially under anoxic conditions where bacteria exploit redox potential in a chain of reactions (Wiedemeier and others, 1998; Chapelle and others, 2007), resulting in biodegradation through reductive dechlorination (Lawrence, 2006).

Gasoline hydrocarbons are among the most intensively and extensively used VOCs (Zogorski and others, 2006) but as a group are relatively insoluble (Mackay and others, 1992) and often evaporate to the atmosphere before entering groundwater systems. MTBE, which was the most commonly used gasoline oxygenate in 2004, was completely or partially banned in some states after the oxygen requirement for gasoline was eliminated in 2005 (Zogorski and others, 2006). MTBE has low sorption to organic material, is slow to biodegrade, and is more soluble than other gasoline compounds, which allow MTBE to move faster and further in aquifers than BTEX and other gasoline components.

\section{Fecal-Indicator Bacteria}

Microbiological analyses are important in determining the associated human-health risk of potentially pathogenic (disease-causing) waterborne organisms. The most common of these analyses include tests for total coliform and E. coli. Coliform bacteria are ubiquitous in the environment and are not always pathogenic. Some strains of E. coli, such as O157:H7, can cause severe illness, and the presence of $E$. coli may indicate general fecal contamination because of the strong association of $E$. coli with the intestines of warm-blooded animals. Any detection of $E$. coli in public drinking-water supplies is considered cause for concern and a violation of health standards (U.S. Environmental Protection Agency, 2001). Although current drinking-water standards for $E$. coli were developed for public water supplies, USEPA criteria can be used to provide a reference point for domestic wells.

\section{Occurrence and Distribution of Fecal-Indicator Bacteria}

The overall detection frequency for $E$. coli in water samples from sites in five networks in the Valley and Ridge aquifers (SCA2, SCA3, TCS, DSM, and TCM) was 43 percent; 
this included detections in water from 28 percent of wells and 91 percent of springs. E. coli detections were less frequent in water samples from sites in siliciclastic-rock aquifers and more frequent in carbonate-rock aquifers (figure 30). Where detected, counts were generally higher in carbonate- than in siliciclastic-rock aquifers and were higher in springs than in wells. Counts rarely exceeded 80 colonies per $100 \mathrm{~mL}$ in samples from most well networks but did so in about 11 percent of samples from springs in the Tennessee River basin (TCS) where counts were reported as high as 660 colonies per $100 \mathrm{~mL}$.

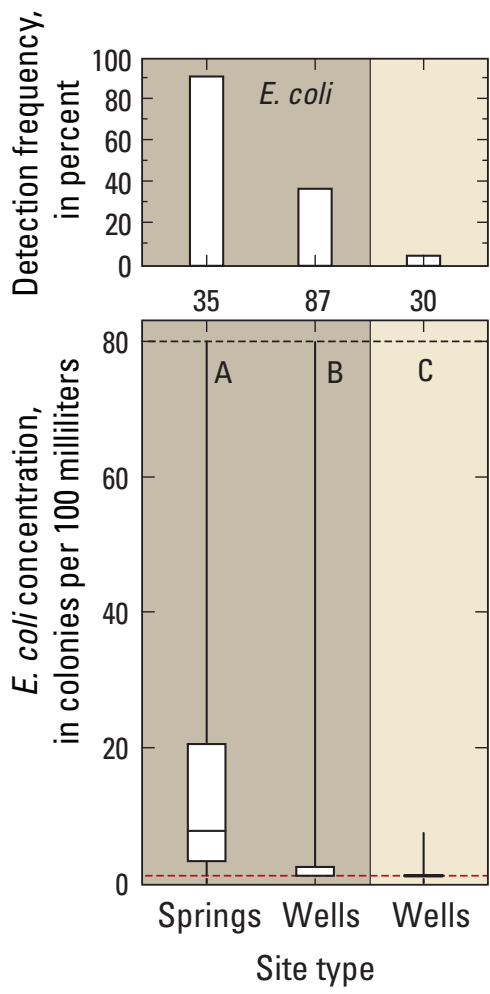

Figure 30. Detection frequency and distribution of concentrations of Escherichia coli bacteria in groundwater samples from well and spring networks in the Valley and Ridge aquifers, 1993-2002.

are reported as less than one with more than 80 colonies were count and are reported as greater than 80 colonies per 100 milliliters, which is the upper detection limit. Samples analyzed using multiple dilution techniques with concentrations greater than the upper detection limit are also reported as greater than 80 colonies per 100 milliliters.
Protection Agency Maximum compounds (U.S. Environmental Note: Analyses with no colonies

\section{Factors Affecting Occurrence of Fecal-Indicator Bacteria}

Overall, the presence of E. coli in samples of groundwater from the Valley and Ridge aquifers appears to be most strongly influenced by the aquifer type and the presence of potential fecal sources. Among samples from wells in agricultural and mixed use areas, E. coli detection frequencies and colony counts were higher in samples from carbonaterock aquifers than in samples from siliciclastic-rock aquifers (fig. 31). This is consistent with earlier observations

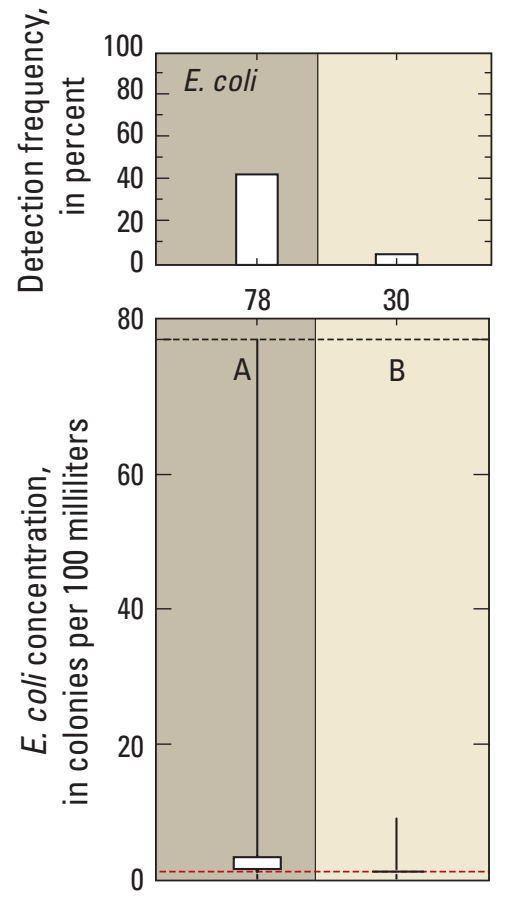

Aquifer type

(Agricultural and mixed land-use wells only) colony per 100 milliliters. Plates considered too numerous to concerning the relatively high rates of transport through

\section{EXPLANATION}

A Statistical group from nonparametric Tukey's test

Maximum value
75th percentile
Median
25th percentile
Minimum value
Siliciclastic-rock
aquifers
Carbonate-rock
aquifers
Upper detection limit
Detection of a single
E. coli colony exceed the USEPA MCL 
carbonate-rock aquifers and their susceptibility to surface contamination. E. coli concentrations were not significantly different among samples from wells surrounded by different land-use types, but their detections were more common in samples from wells in agricultural areas (fig. 32). Further grouping of detection frequencies for wells by aquifer type and land use indicates that land use and aquifer type play an important role in explaining the presence of bacteria (fig. 33). In carbonate-rock aquifers, detections were most frequent in samples from wells in agricultural areas but were not entirely absent even in the samples from wells in undeveloped areas. In siliciclastic-rock aquifers, $E$. coli were detected only in samples from wells in agricultural areas. The highest colony counts tended to be in samples from wells in agricultural

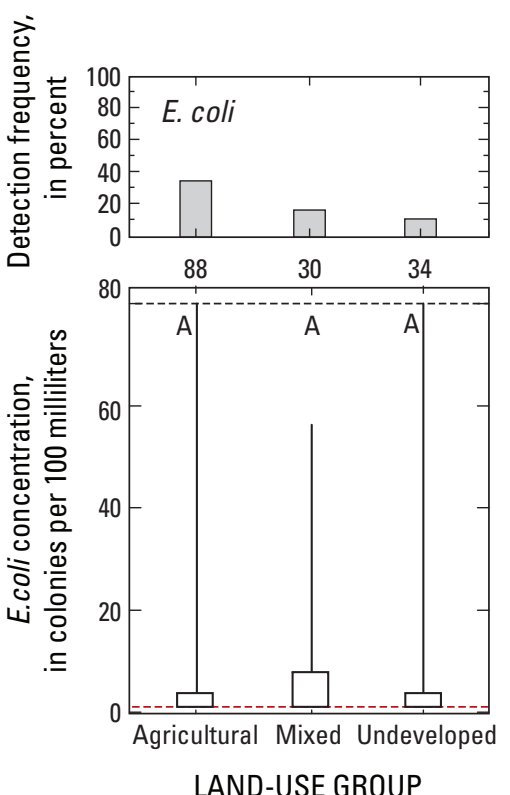

LAND-USE GROUP

\section{EXPLANATION}

88 Number of samples

A Statistical group from nonparametric Tukey's test

Maximum value

75th percentile

Median

25th percentile

Minimum value

------ Upper detection limit

------ Lower detection limit Detection of a single E. coli colony exceeds the USEPA MCL

MCL is U.S. Environmental Protection Agency Maximum Contaminant Level for regulated compounds (U.S. Environmental Protection Agency, 2006).

Note: Analyses with no colonies are reported as less than one colony per 100 milliliters. Plates with more than 80 colonies were considered too numerous to count and are reported as greater than 80 colonies per 100 milliliters, which is the upper detection limit. Samples analyzed using multiple dilution techniques with concentrations greater than the upper detection limit are also reported as greater than 80 colonies per 100 milliliters.

Figure 32. Detection frequency and distribution of concentrations of Escherichia coli bacteria in groundwater samples from wells by land-use group in the Valley and Ridge aquifers, 1993-2002.

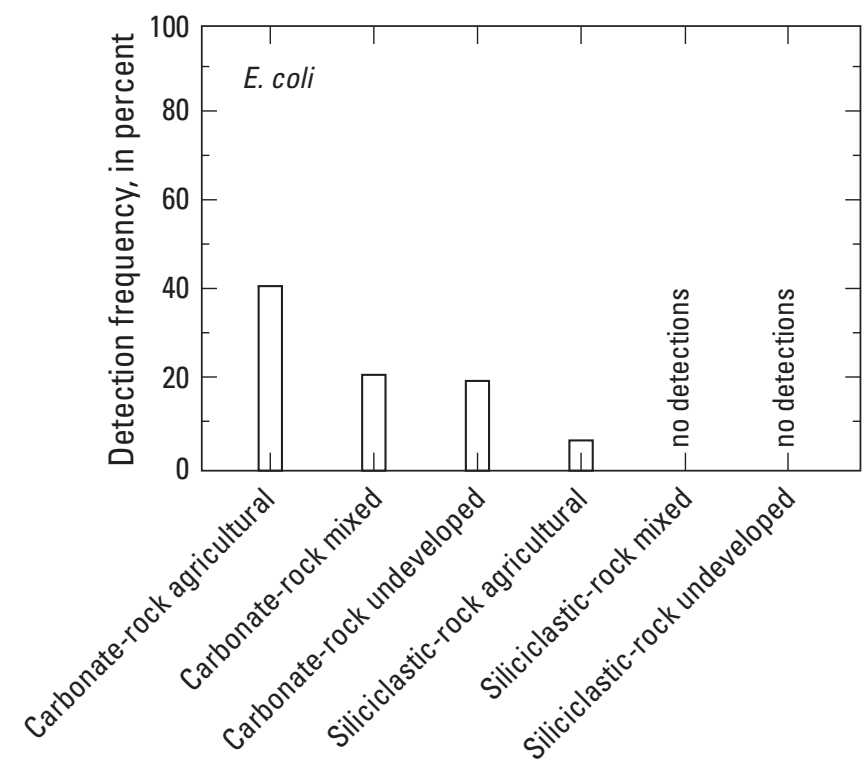

Aquifer type and land-use group

Figure 33. Detection frequency of Escherichia coli bacteria in groundwater samples from wells by land-use group and aquifer type in the Valley and Ridge aquifers, 1993-2002.

areas overlying carbonate-rock aquifers, reflecting the role of agricultural practices and animals as sources of fecal contamination. Higher detections and counts in samples from springs were likewise consistent with the greater susceptibility of springs to surface influences.

\section{Radon}

Radon is a colorless, odorless gas that is produced by the radioactive decay of uranium. It has a relatively short half-life of 3.8 days (Hem, 1985) and is typically detected at higher levels in water from aquifers composed of rocks containing relatively more uranium (Faure, 1986). The health risk from radon in water supplies comes from either ingesting it directly in tap water or breathing radon vapor as it degasses from tap water. Radon is the second leading cause of lung cancer in the United States (U.S. Environmental Protection Agency, 2009). Some of the radon in indoor air comes from radon that escapes from tap water. The USEPA has proposed regulations for radon at two levels for public water supplies (U.S. Environmental Protection Agency, 2009). A proposed MCL of 300 picocuries per liter $(\mathrm{pCi} / \mathrm{L})$ addresses radon in groundwater or a mixture of groundwater and surface water for public supply; an alternative MCL (AMCL) of 4,000 pCi/L has been proposed for radon if the public water supplier enacts community plans to address all sources of radon (known as a multimedia mitigation program). 


\section{Occurrence and Distribution of Radon}

Radon levels were significantly higher in samples from sites in siliciclastic-rock aquifers than in samples from sites in carbonate-rock aquifers (fig. 34). A large number of wells (74 percent) in carbonate- and siliciclastic-rock aquifers produced water with radon levels that exceeded the proposed MCL. However, samples from only five wells (2 percent of wells) exceeded the higher AMCL for radon, and all of these wells were in siliciclastic-rock aquifers. In contrast, siliciclastic-rock aquifers (PSA) also produced some of the lowest radon concentrations in the Valley and Ridge aquifers.

\section{Factors Affecting Concentrations of Radon}

The presence of radon in groundwater can be explained to a large degree by the mineral composition of rocks through which water moves and by other factors, such as exposure to surface influences. Carbonate rocks, for instance, typically contain less uranium than siliciclastic rocks, reflecting
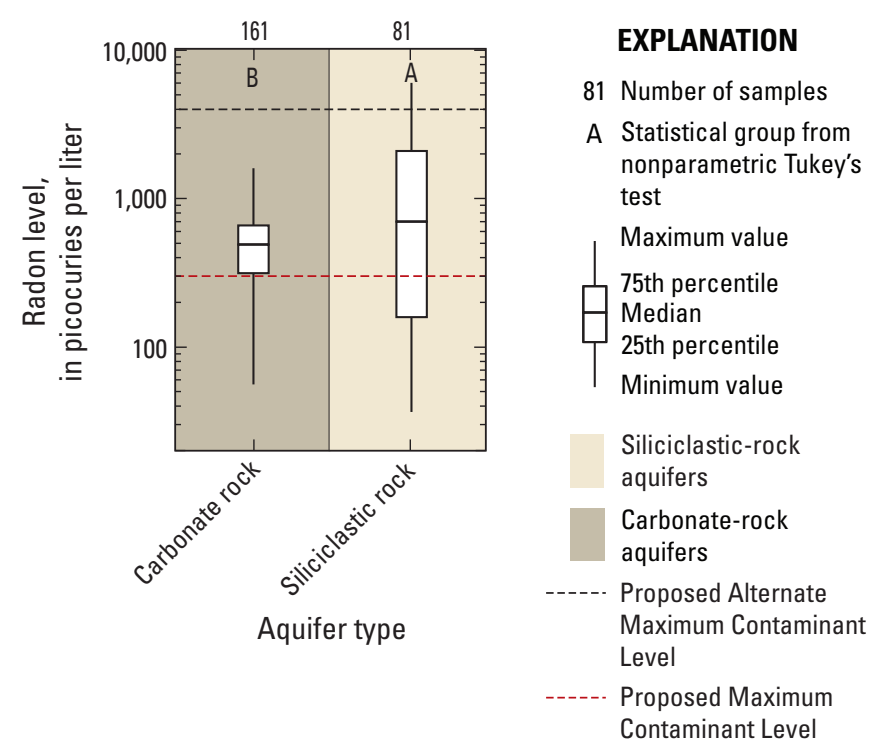

Figure 34. Distribution of radon levels in groundwater samples among carbonate- and siliciclastic-rock aquifers in the Valley and Ridge aquifers, 1993-2002. differences in parent mineralogy and weathering processes. Not surprisingly, radon levels were significantly lower in carbonate-rock aquifers. Differences in radon levels were not significant among carbonate lithologic groups (limestone, dolomite, limestone and dolomite; fig. 35). Among the carbonate-rock aquifers, springs (TCS) produced the lowest radon concentrations. This may reflect degassing from groundwater as hydrostatic pressures decline when the groundwater approaches the spring mouth. Median radon levels were somewhat, but not significantly, higher in water samples from sites in the mixed siliciclastic lithologic group, but sample variance was greatest in samples from wells completed in shale. Relatively larger variance in radon levels in shale and mixed siliciclastic-rock aquifers than in the carbonate-rock aquifers (fig. 35) may result from local differences in mineralogy (Lindsey and Ator, 1996). The variation in the amount of felsic or other uranium-bearing minerals in the parent rocks for a given sedimentary rock formation could explain this high amount of variability.

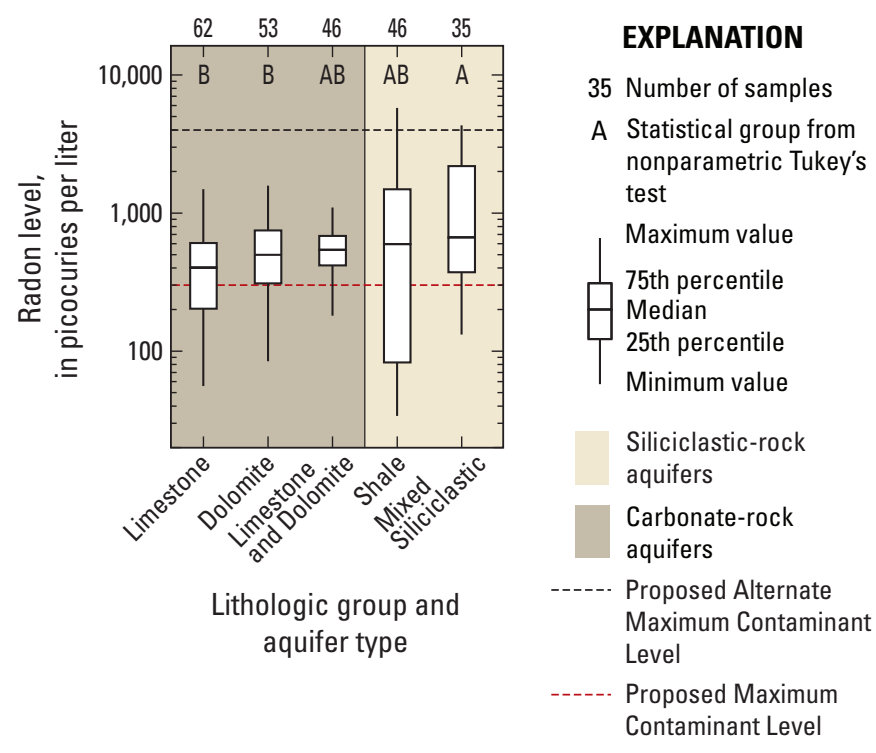

Figure 35. Distribution of radon levels in groundwater samples by lithologic group and aquifer type in the Valley and Ridge aquifers, 1993-2002. 


\section{Distribution of Sites with Background Concentration and Sites with Evidence of Anthropogenic Contamination}

Of the 265 sites sampled in the Valley and Ridge aquifers, 55 showed no clear indication of marked anthropogenic effects as indicated by the absence of pesticide or VOC detections and low nitrate concentrations (less than $2 \mathrm{mg} / \mathrm{L}$ ). The abundance and distribution of these 55 sites provide a point of reference for background conditions and illustrate the spatial extents of human alteration of groundwater quality in the Valley and Ridge aquifers. Most of these sites with background concentrations ( 84 percent) were located in siliciclastic-rock aquifers, even though the sites in siliciclastic-rock aquifers compose only 31 percent of the total sites. Although only 16 percent of the sites overall had surrounding land use classified as undeveloped, 27 percent of the sites with background concentrations were in undeveloped areas. Only 4 percent of wells in carbonate-rock aquifers classified as having agricultural land use surrounding the wells had background concentrations, although this category composed more than 40 percent of the wells overall. Given that a high percentage of background sites are in siliciclastic-rock aquifers and the tendency toward lower dissolved oxygen levels as water ages (fig. 10), it is not surprising that a majority of background sites were anoxic - 40 percent anoxic compared to 33 percent oxic. Further, it may be reasonable to conclude that background conditions are most often observed in older (anoxic) water that has not been influenced by recent landscape change. Of the sites in the siliciclastic-rock aquifers, more than half of the sites (58 percent) had limited or no influence of anthropogenic alteration. This was true of only small fraction of sites ( 2 percent) in carbonate-rock aquifers.

In contrast, a similar number of sites in the total set (57 out of 265) showed clear indications of anthropogenic influence as indicated by one or more pesticides or VOCs exceeding health-related benchmark quotients of 0.1 or nitrate concentrations exceeding $10 \mathrm{mg} / \mathrm{L}$. These sites were nearly all (54 out of 57) located in carbonate-rock aquifers and were associated with agricultural (79 percent) or urban (16 percent) land uses. As might be expected, the majority of sites with anthropogenic influence (96 percent) were oxic, suggesting a system in which relatively young water in carbonate-rock aquifers respond more quickly and clearly to surface processes. Overall, 54 sites (or 30 percent) in carbonate-rock aquifers had groundwater quality at or approaching levels of potential concern for human health. Only 3 sites (4 percent) in siliciclastic-rock aquifers had groundwater quality at or approaching levels of potential concern for human health.

Disparities in the spatial distributions of contaminated and background sites in the Valley and Ridge aquifers suggest opposing associations of groundwater quality with groundwater age and the susceptibility of aquifers to the entry and movement of contaminants. In the presence of such association, and providing that substantial sources exist (coming from land uses), observed groundwater-quality conditions at any location might be expected to correlate with some combination of landscape position and dissolved oxygen. Generally, relative distance downgradient from ridges (as indicated by NLP) was somewhat greater for background sites than for sites of concern (fig. 36). Among carbonate-rock sites, the median NLP of background sites was 0.83 compared to 0.63 for sites of concern. Among siliciclastic-rock sites, the median NLP of background sites was 0.77 compared to 0.70 for sites of concern.

Beyond the well-established associations of oxic conditions with carbonate-rock aquifers and anoxic conditions with siliciclastic-rock aquifers, comparisons of background sites and sites of concern across ranges of NLP and dissolved oxygen suggest three possible inferences.

- First, anthropogenic effects and background conditions can be observed at any position in the landscape.

- Second, oxic conditions in both aquifer types tend to be variable in the middle topographic section and tend toward more anoxic conditions in the lower topographic sections.

- Third, evidence of the importance of physical properties may only become clear where conditions depart from the usual within a given aquifer type. For example, sites of concern in siliciclastic-rock aquifers were all high in dissolved oxygen, and background sites in carbonate-rock aquifers were all low in dissolved oxygen and very low in the topographic section (high NLP).

\section{Summary and Conclusions}

Groundwater samples were collected from 230 wells and 35 springs in 11 networks within the Valley and Ridge aquifers during 1993-2002 as part of the U.S. Geological Survey (USGS) National Water-Quality Assessment (NAWQA) Program. The results of sample analyses from these studies were combined to evaluate the role of rock type, land use, redox conditions, and relative landscape position in the occurrence and distribution of nitrate, pesticides, volatile organic compounds (VOCs), fecal bacteria, and radon.

Patterns of groundwater quality mainly reflect the two principal aquifer types: carbonate-rock and siliciclastic-rock aquifers. Specific conductance, alkalinity, calcium concentrations, and calcite saturation index were typically higher in water samples from sites in carbonate-rock aquifer networks, and iron and manganese concentrations were higher in water from samples in siliciclastic-rock aquifers, except in areas of the Tennessee River basin. Indicators of human effects, such as elevated nitrate concentrations and detections of pesticides and VOCs, were greatest and most frequent in samples from the carbonate-rock aquifers. Results for carbonate-rock aquifers 


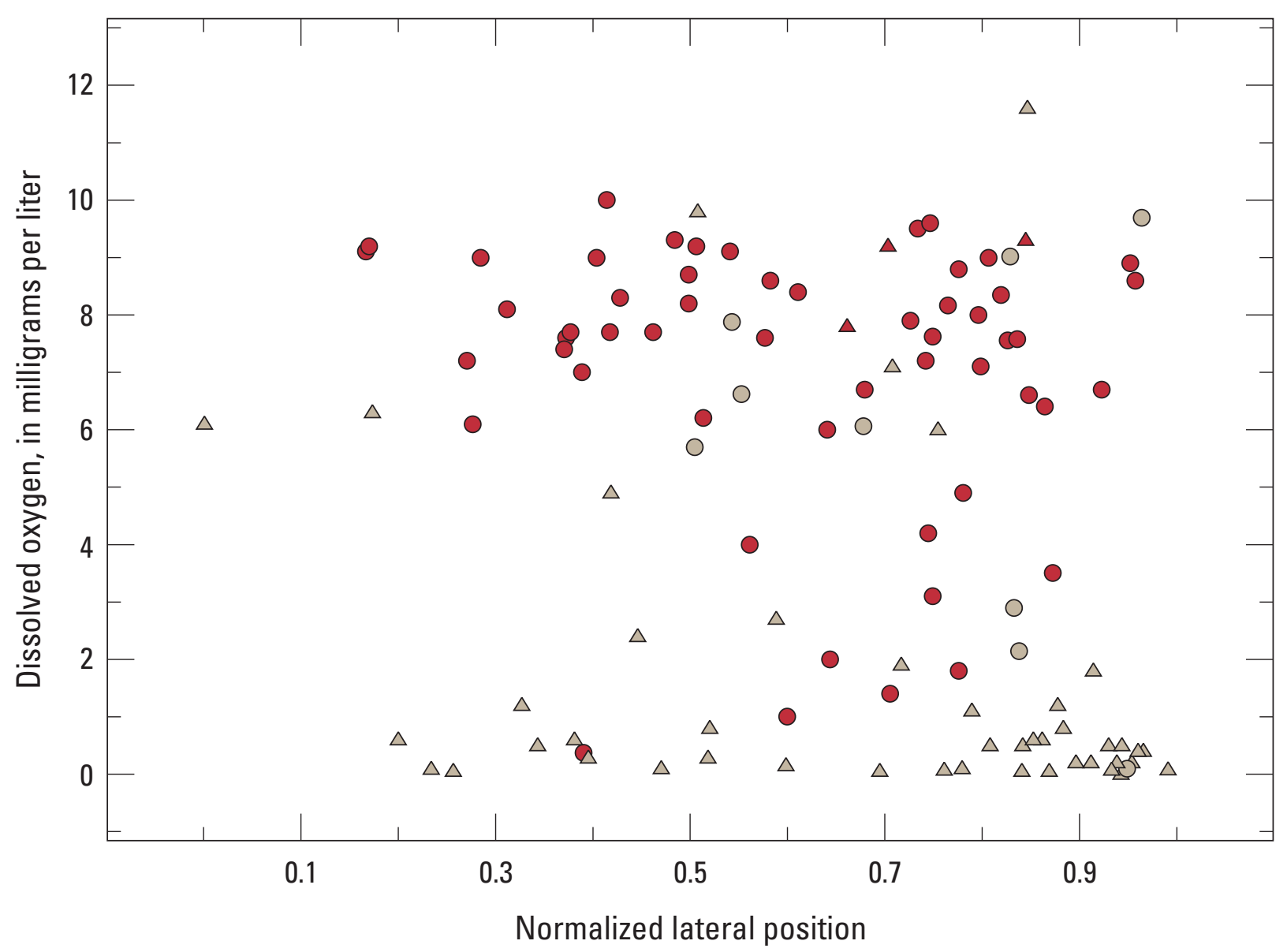

EXPLANATION

$\triangle$ Siliciclastic-rock aquifer - Background concentration

$\Delta$ Siliciclastic-rock aquifer-Concentrations of concern

- Carbonate-rock aquifer - Background concentrations

- Carbonate-rock aquifer - Concentrations of concern

Figure 36. Normalized lateral position and dissolved oxygen concentration in groundwater samples from the Valley and Ridge aquifers, 1993-2002, for sites with background concentrations consisting of no detects for volatile organic compounds or pesticides and nitrate less than 2 milligrams per liter, and sites of concern which had pesticide or volatile organic compound concentrations greater or equal to 0.1 times health benchmark values or nitrate greater than or equal to 10 milligrams per liter. 
may be somewhat skewed by the inclusion of one urban network, which accounted for 65 percent of all VOC detections in the Valley and Ridge aquifers. E. coli counts were significantly higher in water samples from sites in carbonate-rock aquifers, but radon levels were significantly higher in water from sites in siliciclastic-rock aquifers.

The strong relation between aquifer type and water quality is reflected in comparisons between groundwater samples and safe drinking-water standards and humanhealth benchmarks established by the U.S. Environmental Protection Agency (USEPA) and other agencies. The maximum contaminant level (MCL) for nitrate was exceeded in samples from about 12 percent of sites; 90 percent of these exceedances were in samples from carbonate-rock aquifers. The insecticide dieldrin was the only pesticide to exceed a human-health benchmark, and these exceedances were only in samples from urban wells in carbonate-rock aquifers. Three other pesticides (atrazine, simazine, and cyanazine) were within an order of magnitude of benchmarks, generally in agricultural wells in carbonate-rock aquifers. Five VOCs [chloroform, tetrachloroethene (PCE), trichloroethene (TCE), benzene, and carbon tetrachloride] were within an order of magnitude of human-health benchmarks for multiple samples from sites in carbonate-rock aquifers. E. coli were present and exceeded the MCL in about 10 percent of wells in siliciclastic-rock aquifers, 30 percent of wells in carbonaterock aquifers, and 90 percent of springs (all carbonate). Radon levels exceeded a proposed MCL of 300 picocuries per liter (pCi/L) at 74 percent of sites tested without regard to aquifer type, but five samples from sites in siliciclastic-rock aquifers had radon amounts that exceeded the alternative maximum contaminant level of 4,000 pCi/L. Human-health concerns from elevated contaminant concentrations are an important finding, especially because most of the sites in this study are domestic supply wells, which are infrequently studied and commonly unregulated.

Overall, samples from 57 sites had sufficient contamination to be at or approaching levels of potential human health concern for pesticides, VOCs, or nitrate. Samples from 55 sites had no detectable pesticides or VOCs and nitrate concentrations below 2 milligrams per liter $(\mathrm{mg} / \mathrm{L})$. Almost all of the sites with concentrations at or approaching levels of concern (95 percent) were in carbonate-rock aquifers; a majority of background sites ( 84 percent) were in siliciclastic-rock aquifers. Oxic conditions were prevalent in carbonate-rock aquifers and may reflect the relatively young age of water associated with contamination. Background sites in siliciclastic-rock aquifers were more frequently anoxic ( 40 percent) or mixed, which may suggest a prevalence of older water.

The land-use activities around wells and springs were found to be significant in explaining variations in concentration of a number of constituents including nitrate, pesticides, and E. coli. Generally, agricultural activities were associated with the highest concentrations and the greatest number of detections of these constituents. Samples from wells in urban areas had the greatest number of VOC detections. Overall, concentrations and detection frequencies were lowest in undeveloped areas. A measure of the relative topographic position between ridge and stream (NLP) correlated with several water-quality characteristics, but relations were not monotonic. Mineral constituents tend to increase with the residence time of groundwater. Specific conductance, calcite and dolomite saturation indices, and sodium concentrations, all generally increased with relative distance from ridge to valley [normalized lateral position (NLP)]. Dissolved oxygen concentrations decreased as NLP increased but only in the lowest topographic section and particularly in siliciclasticrock aquifers. Dissolved oxygen and redox state positively correlated with detection frequencies for the most commonly detected pesticides except tebuthiuron, suggesting that in the highly oxygenated aquifers, transport may have greater effect than microbial transformation on the presence of pesticides. Deethylatrazine/atrazine ratios were highest in oxic water, as would be expected because atrazine is transformed to deethylatrazine in oxic environments, and atrazine is more stable in anoxic environments.

Wells and springs in carbonate-rock aquifers in the Valley and Ridge are much more likely to have anthropogenic contaminants than wells in siliciclastic-rock aquifers because of a combination of aquifer susceptibility and the land-use practices preferentially located on the land overlying these aquifers. Thus, the most powerful single predictor of elevated groundwater contaminant levels in the Valley and Ridge aquifers is rock type, as shown by higher likelihoods of elevated nutrients, pesticides, VOCs, and bacteria counts in carbonate-rock aquifers and of elevated radon and dissolved mineral concentrations in siliciclastic-rock aquifers. This pattern is largely explained by correlations between rock type and several spatial and temporal factors that determine sources, transport, and accumulation of contaminants in groundwater. Urban centers and agriculture, which are sources of nutrients, pesticides, VOCs, and bacteria, are most prevalent in areas overlying carbonate rocks. Likewise, physical properties of carbonate-rock aquifers, notably high secondary porosity from the dissolution of carbonate minerals, encourage relatively rapid groundwater recharge and transport, increasing the vulnerability of these aquifers to contamination from surface sources and reducing opportunities for attenuation. Longer groundwater residence times and generally anoxic conditions enhance the accumulation of dissolved metals and enhance degradation of contaminants such as nitrate in siliciclasticrock aquifers. Conversely, though generally oxic conditions might tend to accelerate attenuation rates for some contaminants (such as atrazine or toluene), such acceleration is evidently insufficient to have much ameliorative effect given the relatively young groundwater age in carbonate-rock aquifers. Taken together, this complex of mutually reinforcing or offsetting interactions determine the safety, adequacy, and treatment costs of groundwater as a source of water supply in the Valley and Ridge aquifers. 


\section{Acknowledgments}

The authors thank the landowners that allowed access to their private wells and springs. Without their cooperation, this study would not have been possible. The authors also gratefully acknowledge the many well drillers and employees of many state agencies who provided well-construction information for domestic wells. The authors would also like to acknowledge the following reviewers for their input into the development of this report: James A. Kingsbury, George E. Harlow, William J. Wolfe, W. Scott Gain, and Michael W. Bradley, all of the U.S. Geological Survey.

\section{References Cited}

Ator, S.W., Blomquist, J.D., Brakebill, J.W., Denis, J.M., Ferrari, M.J., Miller, C.V., and Zappia, H., 1998, Water quality of the Potomac River Basin, Maryland, Pennsylvania, Virginia, West Virginia, and the District of Columbia, 1992-96: U.S. Geological Survey Circular 1166, 38 p.

Ator, S.W., and Denis, J.M., 1997, Relation of the nitrogen and phosphorus in ground water to land use in four subunits of the Potomac River Basin: U.S. Geological Survey WaterResources Investigations Report 96-4268, 26 p.

Barbash, J.E., and Resek, E.A., 1996, Pesticides in ground water-Distribution, trends, and governing factors: Chelsea, Mich., Ann Arbor Press, 598 p.

Bickford, T.M., Lindsey, B.D., and Beaver, M.R., 1996, Bacteriological quality of ground water used for household supply, Lower Susquehanna River Basin, Pennsylvania and Maryland: U.S. Geological Survey Water-Resources Investigations Report 96-4212, $31 \mathrm{p}$.

Brahana, J.V., Mulderink, D., Macy, J.A., and Bradley, M.W., 1986, Preliminary delineation and description of the regional aquifers of Tennessee-The East Tennessee aquifer system: U.S. Geological Survey Water-Resources Investigations Report 82-4091, 30 p.

Briel, L.I., 1997, Water quality in the Appalachian Valley and Ridge, the Blue Ridge, and the Piedmont Physiographic Provinces, eastern United States: U.S. Geological Survey Professional Paper 1422-D, 115 p.

Carter, J.M., Delzer, G.C., Kingsbury, J.K., and Hopple, J.A., 2007, Concentration data for anthropogenic organic compounds in ground water, surface water, and finished water of selected community water systems in the United States, 2002-05: U.S. Geological Survey Data Series 268, 30 p.
Chapelle, F.H., Novak, John, Parker, John, Campbell, B.G., and Widdowson, M.A., 2007, A framework for assessing the sustainability of monitored natural attenuation: U.S. Geological Survey Circular 1303, 35 p.

Davies, W.E., 1968, Physiography in mineral resources of the Appalachian Region-A compilation of information on the mineral resources, mineral industry, and geology of the Appalachian Region: Geological Survey Professional Paper 580 , U.S. Geological Survey and the U.S. Bureau of Mines, United States Government Printing Office, Washington, D.C.

DeSimone, L.A., Hamilton, P.A., Gilliom, R.J., 2009, Quality of water from domestic wells in principal aquifers of the United States, 1991-2004-Overview of major findings: U.S. Geological Survey Circular 1332, 48 p.

Dicken, C.L., Nicholson, S.W., Horton, J.D., Foose, M.P., and Mueller, J.A.L., 2005a, Integrated geologic map databases for the United States-Alabama, Florida, Georgia, Mississippi, North Carolina, and South Carolina: U.S. Geological Survey Open-File Report 2005-1323, accessed October 31, 2008, at $h t t p: / / p u b s . u s g s . g o v / o f / 2005 / 1323 /$.

Dicken, C.L., Nicholson, S.W., Horton, J.D., Kinney, S.A., Gunther, G., Foose, M.P., and Mueller, J.A.L., 2005b, Integrated geologic map databases for the United States-Delaware, Maryland, New York, Pennsylvania, and Virginia: U.S. Geological Survey Open-File Report 2005-1325, accessed October 31, 2008, at http://pubs.usgs.gov/of/2005/1325/.

Donnelly, C.A., and Ferrari, M.J., 1997, Summary of pesticide data from streams and wells in the Potomac River Basin: U.S. Geological Survey Open-File Report 97-666, accessed December 28, 2009, at http://md.water.usgs.gov/ publications/ofr-97-666/ofr-97-666.html.

Falcone, J., 2003, Coverages for 1:100k stream tiles, assembled from NHD 1:100k streams: U.S. Geological Survey digital data, accessed February 19, 2008, at ftp://disftp.er.usgs.gov/ pub/NAWQA/ecology/GIS_DATA/streams.

Faure, G., 1986, Principles of isotope geology: New York, John Wiley and Sons, Inc., 589 p.

Fenneman, N.M., 1938, Physiography of Eastern United States: New York, McGraw-Hill, 714 p.

Fenneman, N.M., and Johnson, D.W., 1946, Physical divisions of the United States: U.S. Geological Survey Physiography Committee Special Map, scale 1:7,000,000.

Ferrari, M.J., and Ator, S.W., 1995, Nitrate in ground water in the Great Valley Carbonate subunit of the Potomac River Basin: U.S. Geological Survey Water-Resources Investigations Report 95-4099, 6 p. 
Field, M.S., 1993, Karst hydrology and chemical contamination: Journal of Environmental Systems, v. 22, no. 1, p.1-26.

Fields, Scott, 2004, Global nitrogen - Cycling out of control: Environmental Health Perspectives, v. 112, no. 10, p. A556-A563.

Fischer, J.M., Riva-Murray, Karen, Hickman, R.E., Chichester, D.C., Brightbill, R.A., Romanok, R.M., and Bilger, M.D., 2004, Water quality in the Delaware River Basin, Pennsylvania, New Jersey, New York, and Delaware, 1998-2001: U.S. Geological Survey Circular 1227, 38 p.

Foth, H.D., and Schafer J.W., 1980, Soil geography and land use: New York, John Wiley and Sons, Inc., 484 p.

Fuhrer, G.J., Morace, J.L., Johnson, H.M., Rinella, J.F., Ebbert, J.C., Embrey, S.S., Waite, I.R., Carpenter, K.D., Wise, D.R., and Hughes, C.A., 2004, Water quality in the Yakima River Basin, Washington, 1999-2000: U.S. Geological Survey Circular 1237, 44 p.

Furlong, E.T., Anderson, B.D., Werner, S.L., Soliven, P.P., Coffey, L.J., and Burkhardt, M.R., 2001, Methods of analysis by the U.S. Geological Survey National Water Quality Laboratory-Determination of pesticides in water by graphitized carbon-based solid-phase extraction and high-performance liquid chromatography/mass spectrometry: U.S. Geological Survey Water-Resources Investigations Report 01-4134, 73 p.

Gburek, W.J., and Folmar, G.J., 1999, Patterns of contaminant transport in a layered fractured aquifer: Journal of Contaminant Hydrology, v. 37, no. 1-2, p. 87-109.

Gilliom, R.J., Barbash, J.E., Crawford, C.G., Hamilton, P.A., Martin, J.D., Nakagaki, Naomi, Nowell, L.H., Scott, J.C., Stackelberg, P.E., Thelin, G.P., and Wolock, D.M., 2006, The quality of our Nation's waters-Pesticides in the Nation's streams and ground water, 1992-2001: U.S. Geological Survey Circular 1291, 172 p.

Hampson, P.S., Treece, M.W., Jr., Johnson, G.C., Ahlstedt, S.A., and Connell, J.F., 2000, Water quality in the upper Tennessee River Basin, Tennessee, North Carolina, Virginia, and Georgia, 1994-98: U.S. Geological Survey Circular 1205,32 p.

Harlow, G.E., Orndorff, R.C., Nelms, D.L., Weary, D.J., and Moberg, R.M., 2004, Hydrogeology and ground-water availability in the carbonate aquifer system of Frederick County, Virginia: U.S. Geological Survey Scientific Investigations Report 2005-5161, 30 p.
Helsel, D.R., 2005, Nondetects and data analysis-Statistics for censored environmental data: New Jersey, John Wiley and Sons, Inc., $250 \mathrm{p}$.

Helsel, D.R., and Hirsch, R.W., 2002, Statistical methods in water resources: Techniques of Water-Resources Investigations of the U.S. Geological Survey, book 4, 510 p.

Hem, J.D., 1985, Study and interpretation of the chemical characteristics of natural water: U.S. Geological Survey Water-Supply Paper 2254, 263 p.

Hinkle, S.R., Shapiro, S.D., Plummer, L.N., Busenberg, Eurybiades, Widman, P.K., Casile, G.C., and Wayland, J.E., 2010, Estimates of apparent tracer-based piston-flow ages of groundwater from selected sites - National Water-Quality Assessment Program, 1992-2005: U.S. Geological Survey Scientific Investigations Report 2010-5229, 90 p., accessed June 28, 2011, at http://pubs.usgs.gov/sir/2010/5229/.

Hitt, K.J., and Nakagaki, N., 2006, National Water-Quality Assessment (NAWQA) study-unit investigations in the conterminous United States, 1991-2001 [digital data], accessed July 30, 2008, at http://water.usgs.gov/GIS/metadata/ usgswrd/XML/nawqacyc1.xml.

Hollyday, E.F., and Hileman, G.E., 1996, Hydrogeologic terranes and potential yield of water to wells in the Valley and Ridge Physiographic Province in the Eastern and Southeastern United States: U.S. Geological Survey Professional Paper 1422-C, 30 p.

Hollyday, E.F., and Smith, M.A., 1990, Large springs in the Valley and Ridge Province in Tennessee: U.S. Geological Survey Water-Resources Investigations Report 89-4205, 9 p.

Hutson, S.S., Barber, N.L., Kenny, J.F., Linsey, K.S., Lumia, D.S., and Maupin, M.A., 2004, Estimated use of water in the United States in 2000: U.S. Geological Survey Circular $1268,52 \mathrm{p}$.

Johnson, G.C., 2002, Water quality of springs in the Valley and Ridge Physiographic Province in the Upper Tennessee River Basin, 1997: U.S. Geological Survey WaterResources Investigations Report 02-4180, 24 p.

Johnson, T.B., McKay, L.D., Layton, A.C., Jones, S.W., Johnson, G.C., Cashdollar, J.L., Dahling, D.R., Villegas, L.F., Fout, G.S., Williams, D.E., and Sayler, G., 2010, Viruses and bacteria in karst and fractured rock aquifers in East Tennessee, USA: Journal of Groundwater, v. 48, accessed May 13, 2010, at http://www3.interscience.wiley.com/cgi-bin/ fulltext/123325116/PDFSTART. 
Kaufman, D.D., and Kearney, P.C., 1970, Microbial degradation of s-triazine herbicides: Residue Reviews, v. 32, p. 235-265.

Kerle, E.A., Jenkins, J.J., and Vogue, P.A., 1996, Understanding pesticide persistence and mobility for groundwater and surface water protection: Oregon State University Extension Service, EM 8561, 7 p.

Koterba, M.T., Wilde, F.D., and Lapham, W.W., 1995, Ground-water data-collection protocols and procedures for the National Water-Quality Assessment Program-Collection and documentation of water-quality samples and related data: U.S. Geological Survey Water-Resources Investigations Report 95-399, $114 \mathrm{p}$.

Landon, M.K., Belitz, Kenneth, Jurgens, B.C., Kulongoski, J.T., and Johnson, T.D., 2010, Status and understanding of groundwater quality in the Central-Eastside San Joaquin Basin, 2006 - California GAMA Priority Basin Project: U.S. Geological Survey Scientific Investigations Report 2009-5266, $97 \mathrm{p}$.

Lapham, W.W., Wilde, F.D., and Koterba, M.T., 1997, Guidelines and standard procedures for studies of ground-water quality-Selection and installation of wells, and supporting documentation: U.S. Geological Survey Water-Resources Investigations Report 96-4233, $110 \mathrm{p}$.

Lawrence, S.J., 2006, Description, properties, and degradation of selected volatile organic compounds detected in ground water-A review of selected literature: U.S. Geological Survey Open-File Report 2006-1338, 62 p., available at http:// pubs.usgs.gov/ofr/2006/1338/.

Leibundgut, C., 1998, Vulnerability of karst aquifers, Karst Hydrology, Proceedings of Workshop W2 held at Rabat, Morocco, April-May 1997, IAHS Publ. no. 247, 16 p.

Lindsey, B.D., and Ator, S.W., 1996, Radon in ground water of the Lower Susquehanna and Potomac River Basins: U.S. Geological Survey Water-Resources Investigations Report 96-4156, $6 \mathrm{p}$.

Lindsey, B.D., Berndt, M.P., Katz, B.G., Ardis, A.F., and Skach, K.A., 2009, Factors affecting water quality in selected carbonate aquifers in the United States, 1993-2005: U.S. Geological Survey Scientific Investigations Report 2008-5240, $117 \mathrm{p}$.

Lindsey, B.D., Breen, K.J., Bilger, M.D., and Brightbill, R.A., 1998, Water quality in the Lower Susquehanna River Basin, Pennsylvania and Maryland, 1992-95: U.S. Geological Survey Circular 1168, 38 p.
Lindsey, B.D., Falls, W.F., Ferrari, M.J., Zimmerman, T.M., Harned, D.A., Sadorf, E.M., and Chapman, M.J., 2006, Factors affecting occurrence and distribution of selected contaminants in ground water from selected areas in the Piedmont Aquifer System, eastern United States, 19932003: U.S. Geological Survey Scientific Investigations Report 2006-5104, 72 p.

Lindsey, B.D., Katz, B.G., Berndt, M.P., Ardis, A.F., and Skach, K.A., 2010, Relations between sinkhole density and anthropogenic contaminants in selected carbonate aquifers in the eastern United States: Environmental Earth Sciences, v. 60 , no. 5 , p. $1073-1090$.

Lindsey, B.D., Loper, C.A., and Hainly, R.A., 1997, Nitrate in ground water and stream base flow in the Lower Susquehanna River Basin, Pennsylvania and Maryland: U.S. Geological Survey Water-Resources Investigations Report 97-4146, $66 \mathrm{p}$.

Lindsey, B.D., Phillips, S.W., Donnelly, C.A., Speiran, G.K., Plummer, L.N., Bohlke, J.F., Focazio, M.J., Burton, W.C., and Busenberg, Eurybiades, 2003, Residence times and nitrate transport in ground water discharging to streams in the Chesapeake Bay Watershed: U.S. Geological Survey Water-Resources Investigations Report 03-4035, 201 p.

Lindsey, B.D., Rasberry, J.S., and Zimmerman, T.M., 2002, Microbiological quality of noncommunity supply wells in carbonate and crystalline aquifers of Pennsylvania: U.S. Geological Survey Water-Resources Investigations Report 01-4076, $30 \mathrm{p}$.

Lloyd, O.B., Jr., and Lyke, W.I., 1995, Ground water atlas of the United States-Segment 10, Illinois, Indiana, Kentucky, Ohio, and Tennessee: U.S. Geological Survey Hydrologic Investigations Atlas 730-K, $30 \mathrm{p}$.

Loop, C., and White, W.B., 2001, A conceptual model for DNAPL transport in karst ground water basins: Ground Water, v. 39, no. 1, p. 119-127.

Mackay, Donald, Shiu, W.Y., and Ma, K.C., 1992, Illustrated handbook of physical-chemical properties of environmental fate for organic chemicals, Volume 1, Monochromatic hydrocarbons, chlorobenzenes and PCBs: Chelsea, Mich., Lewis Publishers, 697 p.

Martin, J.D., 1999, Quality of pesticide data from environmental water samples collected for the National Water-Quality Assessment Program, 1992-96, and examples of the use of quality-control information in water-quality assessments, accessed June 23, 2009, at http://water.usgs.gov/nawqa/ pnsp/pubs/qcsummary.html. 
Martin, J.D., 2001, Variability of pesticide detections and concentrations in field replicate water samples collected for the National Water-Quality Assessment Program, 1992-97: U.S. Geological Survey Water-Resources Investigations Report 01-4178, 84 p.

Martin, J.D., Gilliom, R.J., and Schertz, T., 1998, Summary and evaluation of pesticides in field blanks collected for the National Water-Quality Assessment Program, 1992-1995: U.S. Geological Survey Open-File Report 98-4112, 102 p.

Maupin, M.A., and Barber, N.L., 2005, Estimated withdrawals from principal aquifers in the United States, 2000: U.S. Geological Survey Circular 1279, 47 p.

Maupin, M.A., and Arnold, T.L., 2010, Estimates for selfsupplied domestic withdrawals and population served for selected principal aquifers, calendar year 2005: U.S. Geological Survey Open-File Report 2010-1223, 10 p.

McCoy, K.J., and Kozar, M.D., 2007, Relation of chlorofluorocarbon ground-water age dates to water quality in the aquifers of West Virginia: USGS Scientific Investigations Report 2006-5221, 37 p.

McGuinness, C.L., 1963, The role of ground water in the national water situation: U.S. Geological Survey WaterSupply Paper 1800, 1121 p.

McMahon, P.B., and Chapelle, F.H., 2008, Redox processes and water quality of selected principal aquifer systems: Ground Water, v. 46, no. 2, p. 259-271.

Meyer, Gerald, 1965, Geology and mineral resources of the region, in Schneider, W.J., and others, Water resources of the Appalachian region, Pennsylvania to Alabama: U.S. Geological Survey Hydrologic Atlas 198, Sheet 3.

Milanovic, P.T., 1981, Karst hydrogeology: Denver, Water Resources Publications, $434 \mathrm{p}$.

Miller, J.A., 1990, Ground water atlas of the United StatesSegment 6, Alabama, Florida, Georgia, South Carolina: U.S. Geological Survey Hydrologic Investigations Atlas 730-G, $28 \mathrm{p}$.

Musgrove, M., and Banner, J.L., 2004, Controls on the spatial and temporal variability of vadose dripwater geochemistry-Edwards Aquifer, Central Texas: Geochimica et Cosmochimica Acta, v. 68, p. 1007-1020.

Nakagaki, Naomi, and Wolock, D.M., 2005, Estimation of agricultural pesticide use in drainage basins using land cover maps and county pesticide data: U.S. Geological Survey Open-File Report 2005-1188, 46 p.
Nakagaki, Naomi, Price, C.V., Falcone, J.A., Hitt, K.J., and Ruddy, B.C., 2007, Enhanced national land cover data 1992 (NLCDe 92) [digital data], accessed March 31, 2008, at http://water.usgs.gov/GIS/metadata/usgswrd/XML/ nlcde92.xml.

Nelms, D.L., Harlow, G.E., Plummer, L.N., and Busenberg, E., 2003, Aquifer susceptibility in Virginia, 1998-2000: U.S. Geological Survey Water-Resources Investigations Report 03-4278, $58 \mathrm{p}$.

Nicholson, S.W., Dicken, C.L., Horton, J.D., Foose, M.P., Mueller, J.A.L., and Hon, R., 2007, Preliminary integrated geologic map databases for the United States-Connecticut, Maine, Massachusetts, New Hampshire, New Jersey, Rhode Island, and Vermont, Version 1.1: U.S. Geological Survey Open-File Report 2005-1272, accessed October 31, 2008, at http://pubs.usgs.gov/of/2006/1272/.

Nicholson, S.W., Dicken, C.L., Horton, J.D., Labay, K.A., Foose, M.P., and Mueller, J.A.L., 2005, Preliminary integrated geologic map databases for the United StatesKentucky, Ohio, Tennessee, and West Virginia, Version 1.1: U.S. Geological Survey Open-File Report 2005-1324, accessed October 31, 2008, at http://pubs.usgs.gov/ of/2005/1324/.

Nolan, B.T., 1999, Nitrate behavior in ground waters of the southeastern USA: Journal of Environmental Quality, v. 28, p. $1518-1527$.

Otton, J.K., 1992, The geology of radon: U.S. Geological Survey, General Interest Publications of the U.S. Geological Survey, $28 \mathrm{p}$.

Price, C.V., Nakagaki, N., Hitt, K.J., and Clawges, R.M., 2007, Enhanced historical land-use and land-cover data sets of the U.S. Geological Survey: U.S. Geological Survey Data Series 240 [digital data], accessed June 25, 2010, at $h t t p: / / p u b s . u s g s . g o v / d s / 2006 / 240$.

PRISM Group at Oregon State University, 2006a, United States average monthly or annual maximum temperature, 1971-2000: PRISM Group at Oregon State University digital data, accessed May 19, 2009, at http://www.prism.oregonstate.edu/products/matrix. phtml vartype $=$ tmax $\&$ view $=$ data.

PRISM Group at Oregon State University, 2006b, United States average monthly or annual minimum temperature, 1971-2000: PRISM Group at Oregon State University digital data, accessed May 19, 2009, at http://www.prism.oregonstate.edu/products/matrix. phtml? vartype $=$ tmin \&view $=$ data. 
PRISM Group at Oregon State University, 2006c, United

States average monthly or annual precipitation, 1971-2000: PRISM Group at Oregon State University digital data, accessed May 19, 2009, at http://www.prism.oregonstate. edu/products/matrix.phtml? vartype $=$ ppt\&view $=$ data .

Quinlan, J.F., and Ewers, R.O., 1985, Ground-water flow in limestone terranes - Strategy rationale and procedure for reliable, efficient monitoring of ground-water quality in karst areas, in National Symposium and Exposition on Aquifer Restoration and Ground-Water Monitoring, 5th, Columbus, Ohio, Proceedings: Dublin, Ohio, National Water Well Association, p. 197-234.

Quinlan, J.F., Smart, P.L., Schindel, G.M., Alexander, E.C., Edwards, A.J., and Smith, A.R., 1991, Recommended administrative/regulatory definition of karst aquifers, principles for classification of carbonate aquifers, practical evaluation of vulnerability of karst aquifers, and determination of optimum sampling frequency at springs, in Conference on Hydrogeology, Ecology, Monitoring, and Management of Ground Water in Karst terrains, 3rd, Proceedings: Ground Water Management (Publisher: Dublin, Ohio, Water Well Journal Publishing Co.), v. 10, p. 573-635.

Ruddy, B.C., Lorenz, D.L., and Mueller, D.K., 2006, Countylevel estimates of nutrient inputs to the land surface of the conterminous United States, 1982-2001: U.S. Geological Survey Scientific Investigations Report 2006-5012, 17 p.

Schnabel, R.R., Urban, J.B., and Gburek, W.J., 1993, Hydrologic controls in nitrate, sulfate, and chloride concentrations: Journal of Environmental Quality, v. 22, p. 589-596.

Seaber, P.R., Brahana, J.V., and Hollyday, E.F., 1988, Region 20, Appalachian Plateaus and Valley and Ridge, in Back, W., Rosenshein, J.S., and Seaber, P.R., eds., Hydrogeology: Boulder, Colo., Geological Society of America, The Geology of North America, v. O-2, 524 p.

Seybold, C.A., and Mersie, W., 1999, Metolachlor fate and mobility in a tidal wetland soil: Wetlands, v. 19 , no. 1 , p. $228-235$.

Siwiec, S.F., Hainly, R.A., Lindsey, B.D., Bilger, M.D., and Brightbill, R.A., 1997, Water-quality assessment of the Lower Susquehanna River Basin, Pennsylvania and Maryland - Design and implementation of water-quality studies, 1992-95: U.S. Geological Survey Open-File Report 97-583, $121 \mathrm{p}$.

Spalding, R.F., and Exner, M.E., 1993, Occurrence of nitrate in groundwater-A review: Journal of Environmental Quality, v. 22, p. 392-402.

Stueber, A.M., and Criss, R.E., 2005, Origin and transport of dissolved chemicals in a karst watershed, southwestern Illinois: Journal of the American Water Resources Association, v. 41, no. 2, p. 267-290.
Sun, P-C.P., Criner, J.H., and Poole, J.L., 1963, Large springs of East Tennessee: U.S. Geological Survey Water-Supply Paper 1755, $52 \mathrm{p}$.

Swain, L.A., Hollyday, E.F., Daniel, C.C., III, and Zapecza, O.S., 1991, Plan of study for the regional aquifer-system analysis of the Appalachian Valley and Ridge, Piedmont, and Blue Ridge Physiographic Provinces of the eastern and southeastern United States, with a description of study area geology and hydrogeology: U.S. Geological Survey WaterResources Investigations Report 91-4066, 44 p.

Toccalino, P.L., Norman, J.E., Booth, N.L., and Zogorski, J.S., 2008, Health-based screening levels-A tool for evaluating what water-quality data may mean to human health: U.S. Geological Survey, National Water-Quality Assessment Program, accessed April 1, 2009, at http://water.usgs.gov/ nawqa/HBSL/.

Trapp, H., Jr., and Horn, M.A., 1997, Ground water atlas of the United States-Segment 11, Delaware, Maryland, New Jersey, North Carolina, Pennsylvania, Virginia, West Virginia: U.S. Geological Survey Hydrologic Investigations Atlas 730-L, 24 p.

U.S. Army Corps of Engineers, 2001, Automated IFSAR Terrain Analysis System, Defense Advanced Research Projects Agency (DOD) Information Sciences Office, accessed February 20, 2008, at http://www.tec.army.mil/publications/ ifsar/lafinal08_01/cover/cover_frame.htm.

U.S. Bureau of the Census, 1990a, 1990 state \& state equivalent areas [digital data], accessed June 11, 2008, at http://www.census.gov/geo/www/cob/st1990.html.

U.S. Bureau of the Census, 1990b, 1990 generalized block groups for the conterminous United States: Washington, D.C., U.S. Bureau of the Census, accessed September 09, 2006, at http://www.census.gov/geo/www/cob/bg1990.html.

U.S. Bureau of the Census, 1992a, 1990 Census of Population and Housing: Summary Tape File 1A: Washington, D.C., U.S. Bureau of the Census, accessed September 09, 2006, at ftp://ftp.census.gov/census_1990/.

U.S. Bureau of the Census, 1992b, Census of population and housing - Summary tape file 3A: Washington, D.C., U.S. Bureau of the Census, accessed September 09, 2006, at ftp://ftp.census.gov/census_1990/.

U.S. Bureau of the Census, 1999, 1999 Metropolitan Statistical Areas: U.S. Bureau of the Census, Geography Division, accessed April 24, 2008, at http://www.census.gov/geo/ www/cob/ma1999.html.

U.S. Bureau of the Census, 2001a, Cartographic Boundary Files for Census 2000 Block Groups: U.S. Bureau of the Census, Geography Division, accessed April 24, 2008, at $h t t p: / / w w w . c e n s u s . g o v / g e o / w w w / c o b / b g 2000 . h t m l$. 
U.S. Bureau of the Census, 2001b, CensusCD 2000 Short Form Blocks: U.S. Bureau of the Census, Geography Division, accessed April 24, 2008, at http://www.geolytics.com/ census2000.htm.

U.S. Department of Agriculture, 1986, Urban hydrology for small watersheds, Technical Release 55 (2d ed.): NTIS PB87-101580, Washington, D.C., Soil Conservation Service.

U.S. Department of Agriculture, 2003, National soil survey handbook, Title 430-VI: U.S. Department of Agriculture, Natural Resources Conservation handbook, National Resources Conservation Service, National Soil Survey Center.

U.S. Department of Agriculture, Natural Resources Conservation Service, 1994, State Soil Geographic (STATSGO) data base for the United States and Puerto Rico [digital data on CDROM]: Ft. Worth, Tex., U.S. Department of Agriculture.

U.S. Department of Agriculture, Natural Resources Conservation Service, 1999, 12-digit watershed boundary data 1:24,000: National Cartography and Geospatial Center digital data, accessed February 19, 2008, at http://datagateway. nrcs.usda.gov/.

U.S. Environmental Protection Agency, 1990, The Clean Air Act amendments: Washington, D.C., U.S. Congress 101st, Sec. 219, p. S.1630-1938, accessed March 30, 2009, at http://www.epa.gov/oar/caa/caaa.txt.

U.S. Environmental Protection Agency, 1991, Test methods for Escherichia coli in drinking water-Test Method 1105: EPA/600/4-91/016, 2 p.

U.S. Environmental Protection Agency, 1992, Secondary Drinking Water Regulations - Guidance for nuisance chemicals: EPA 810/K-92-001, accessed May 18, 2009, at http:// www.epa.gov/OGWDW/consumer/2ndstandards.html.

U.S. Environmental Protection Agency, 1997, Drinking water advisory - Consumer acceptability advice and health effects analysis on methyl-tertiary-butyl ether: Washington, D.C., U.S. Environmental Protection Agency, Office of Water, EPA-822-F-97-009.

U.S. Environmental Protection Agency, 2001, Total coliform rule-A quick reference guide: Washington, D.C., U.S. Environmental Protection Agency, Office of Water, EPA 816-F-010035, 2 p.
U.S. Environmental Protection Agency, 2002, Method 1603-Escherichia coli (E. coli) in water by membrane filtration using modified membrane-thermotolerant Escherichia coli agar (modified mTEC): Washington, D.C., U.S. Environmental Protection Agency, Office of Water, EPA821-R-02-023, 9 p.

U.S. Environmental Protection Agency, 2003, Contaminant candidate list regulatory determination support document for Aldrin and Dieldrin: Washington, D.C., U.S. Environmental Protection Agency, Office of Water, Standards and Risk Management Division, EPA 815-R-03-010, 48 p.

U.S. Environmental Protection Agency, 2006, 2006 Edition of the drinking water standards and health advisories: Washington, D.C., U.S. Environmental Protection Agency, Office of Water, EPA 822-R-06-013, 18 p.

U.S. Environmental Protection Agency, 2007, List of reformulated gasoline program areas: Office of Transportation and Air Quality, accessed March 30, 2009, at http://epa.gov/ otaq/rfg/whereyoulive.htm.

U.S. Environmental Protection Agency, 2009, Technical Fact Sheet-Proposed radon in drinking water rule, accessed May 15, 2009, at http://www.epa.gov/safewater/radon/ remove/fact.html.

U.S. Geological Survey, 1985, National Water Summary, 1984-Hydrologic events, selected water-quality trends, and ground-water resources: U.S. Geological Survey WaterSupply Paper 2275, 467 p.

U.S. Geological Survey, 1988, National Water Summary, 1986-Hydrologic events and ground-water quality: U.S. Geological Survey Water-Supply Paper 2325, 560 p.

U.S. Geological Survey, 1999, The quality of our Nation's waters - Nutrients and pesticides: U.S. Geological Survey Circular 1225, 82 p.

U.S. Geological Survey, 2002, Shuttle Radar Topography Mission (SRTM) Elevation Dataset: SDE raster digital data, accessed July 27, 2010, at http://edcsns17.cr.usgs.gov/ EarthExplorer/.

U.S. Geological Survey, 2003, Principal aquifers of the 48 conterminous United States, Hawaii, Puerto Rico, and the U.S. Virgin Islands, accessed April 22, 2008, at http://www. nationalatlas.gov/mld/aquifrp.html. 
U.S. Geological Survey, variously dated, National field manual for the collection of water-quality data : U.S. Geological Survey Techniques of Water-Resources Investigations, book 9, chaps. A1-A9, available online at http://pubs.water.usgs. gov/twri9A.

U.S. National Library of Medicine, 2008, U.S. National Library of Medicine ChemID plus Lite database of the U.S. National Institute of Health, accessed May 5, 2009, at http://chem.sis.nlm.nih.gov/chemidplus/chemidlite.jsp.

Vogelmann, J.E., Howard, S.M., Yang, L., Larson, C.R., Wylie, B.K., and VanDriel, N., 2001, Completion of the 1990's national land cover dataset for the conterminous United States from Landsat Thematic Mapper data and ancillary data sources: Photogrammetric Engineering and Remote Sensing, v. 67, p. 650-662.

Vogue, P.A., Kerle, E.A., and Jenkins J.J., 1994, Oregon State University Extension Pesticide Properties Database, in National Pesticide Information Center, accessed May 4, 2009, at http://npic.orst.edu/ppdmove.htm.

Ward, M.H., deKok, T.M., Levallois, P., Brender, J., Gulis, G., Nolan, B.T., and VanDerslice, J., 2005, Workgroup reportDrinking-water nitrate and health-Recent findings and research needs: Environmental Health Perspectives, v. 113, no. 11, p. 1607-1614.

Werner, S.L., Burkhardt, M.R., and DeRusseau, S.N., 1996, Methods of analysis by the U.S. Geological Survey National Water Quality Laboratory-Determination of pesticides in water by Carbopak-B solid-phase extraction and high-performance liquid chromatography: U.S. Geological Survey Open-File Report 96-216, 42 p.

White, W.B., 1988, Geomorphology and hydrology of karst terrains: New York, Oxford University Press, 464 p.

Wiedemeier, T.H., Swanson, M.A., Moutoux, D.E., Gordon, E.K., Wilson, J.T., Wilson, B.H., Kampbell, D.H., Haas, P.E., Miller, R.N., Hansen, J.E., and Chapelle, F.H., 1998, Technical protocol for evaluating natural attenuation of chlorinated solvents in ground water: Cincinnati, Ohio, U.S. Environmental Protection Agency, National Risk Management Research Laboratory, Office of Research and Development, EPA/600/R-98/128, 244 p.

Wolfe, W.J., 1996, Hydrology and tree-distribution patterns of karst wetlands at Arnold Engineering Development Center, Tennessee: U.S. Geological Survey Water-Resources Investigations Report 96-4277, 46 p.
Wolfe, W.J., Haugh, C.J., Webbers, A., and Diehl, T.H., 1997, Preliminary conceptual models of the occurrence, fate, and transport of chlorinated solvents in karst regions of Tennessee: U.S. Geological Survey Water-Resources Investigations Report 97-4097, 80 p.

Wolock, D.M., 1997, STATSGO soil characteristics for the conterminous United States: U.S. Geological Survey OpenFile Report 97-656 [digital data], accessed February 17, 2004, at http://water.usgs.gov/lookup/getspatial?muid.

Wolock, D.M., 2003, Estimated mean annual natural groundwater recharge in the conterminous United States: U.S. Geological Survey Open-File Report 03-311 [digital data], accessed April 21, 2008, at http://water.usgs.gov/GIS/ metadata/usgswrd/XML/rech48grd.xml.

Yager, R.M., Voss, C.I., and Southworth, S., 2009, Comparison of alternative representations of hydraulic-conductivity anisotropy in folded fractured-sedimentary rock-Modeling groundwater flow in the Shenandoah Valley (USA): Hydrogeology Journal, v. 17, no. 5, p. 1111-1131.

Zaugg, S.D., Sandstrom, M.W., Smith, S.G., and Fehlberg, K.M., 1995, Methods of analysis by the U.S. Geological Survey National Water Quality Laboratory-Determination of pesticides in water by $\mathrm{C}-18$ solid-phase extraction and capillary-column gas chromatography/mass spectrometry with selected-ion monitoring: U.S. Geological Survey Open-File Report 95-181, 49 p., available online at $h t t p: / /$ wwwnwql.cr.usgs.gov/Public/pubs/OFR95-181/OFR95-181. html.

Zimmerman, T.M., Zimmerman, M.L., and Lindsey, B.D., 2001, Relation between selected well-construction characteristics and occurrence of bacteria in private householdsupply wells, south-central and southeastern Pennsylvania, 2001: U.S. Geological Survey Water-Resources Investigations Report 01-4206, 22 p.

Zogorski, J.S., Carter, J.M., Ivahnenko, I., Lapham, W.W., Moran, M.J., Rowe, B.L., Squillace, P.J., and Toccalino, P.L., 2006, The quality of our Nation's waters-Volatile organic compounds in the Nation's ground water and drinking-water supply wells: U.S. Geological Survey Circular 1292, $101 \mathrm{p}$. 


\section{Tables 23 and 24}




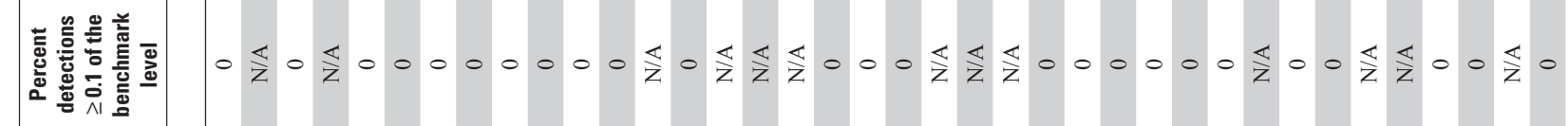

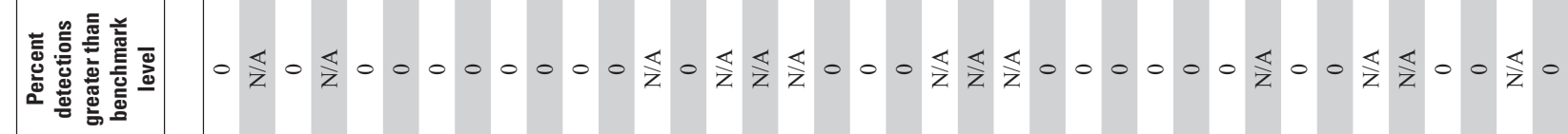

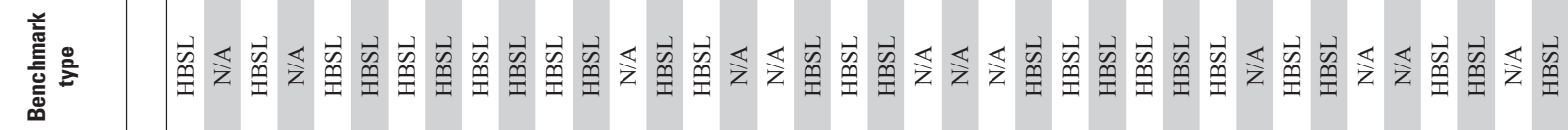

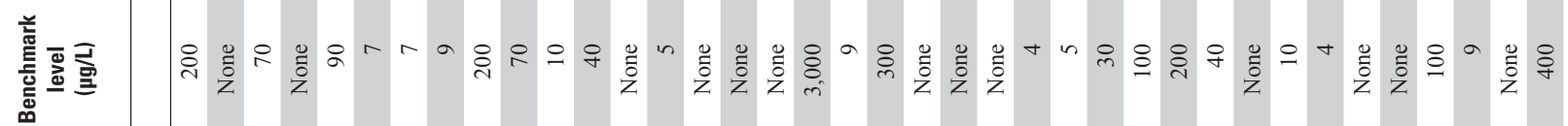

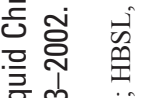

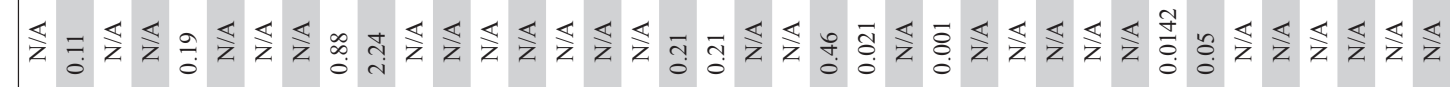

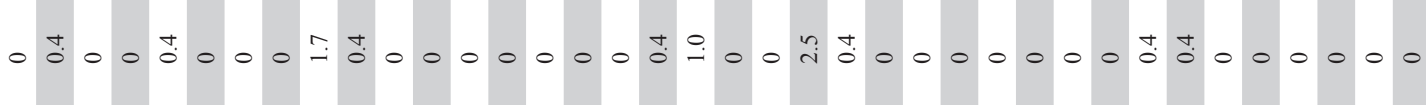

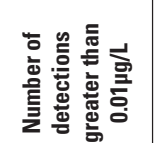
.⿳亠二口⿱幺小

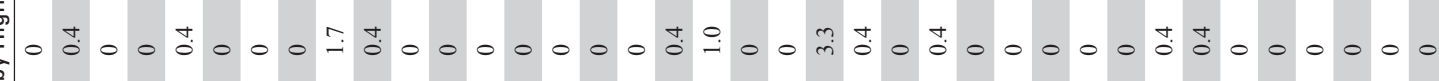

$0-00-0004-0000000-400,-0-00000-7000000$ 竧 ปี สี่

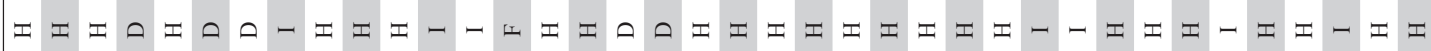

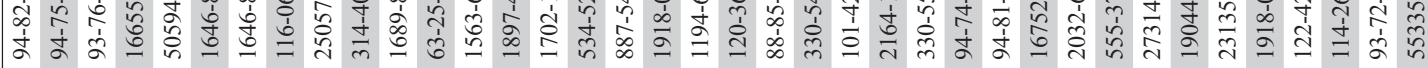




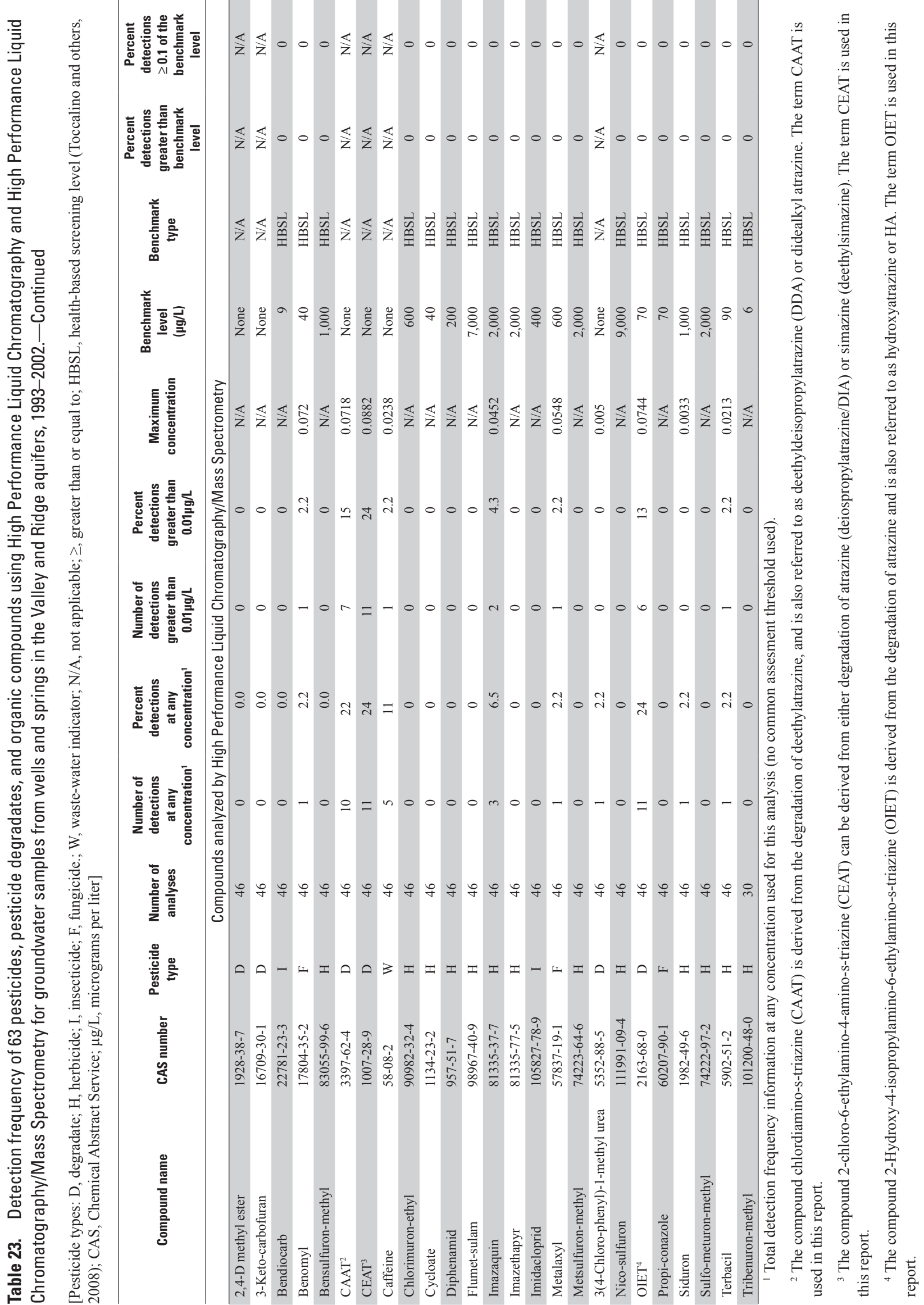




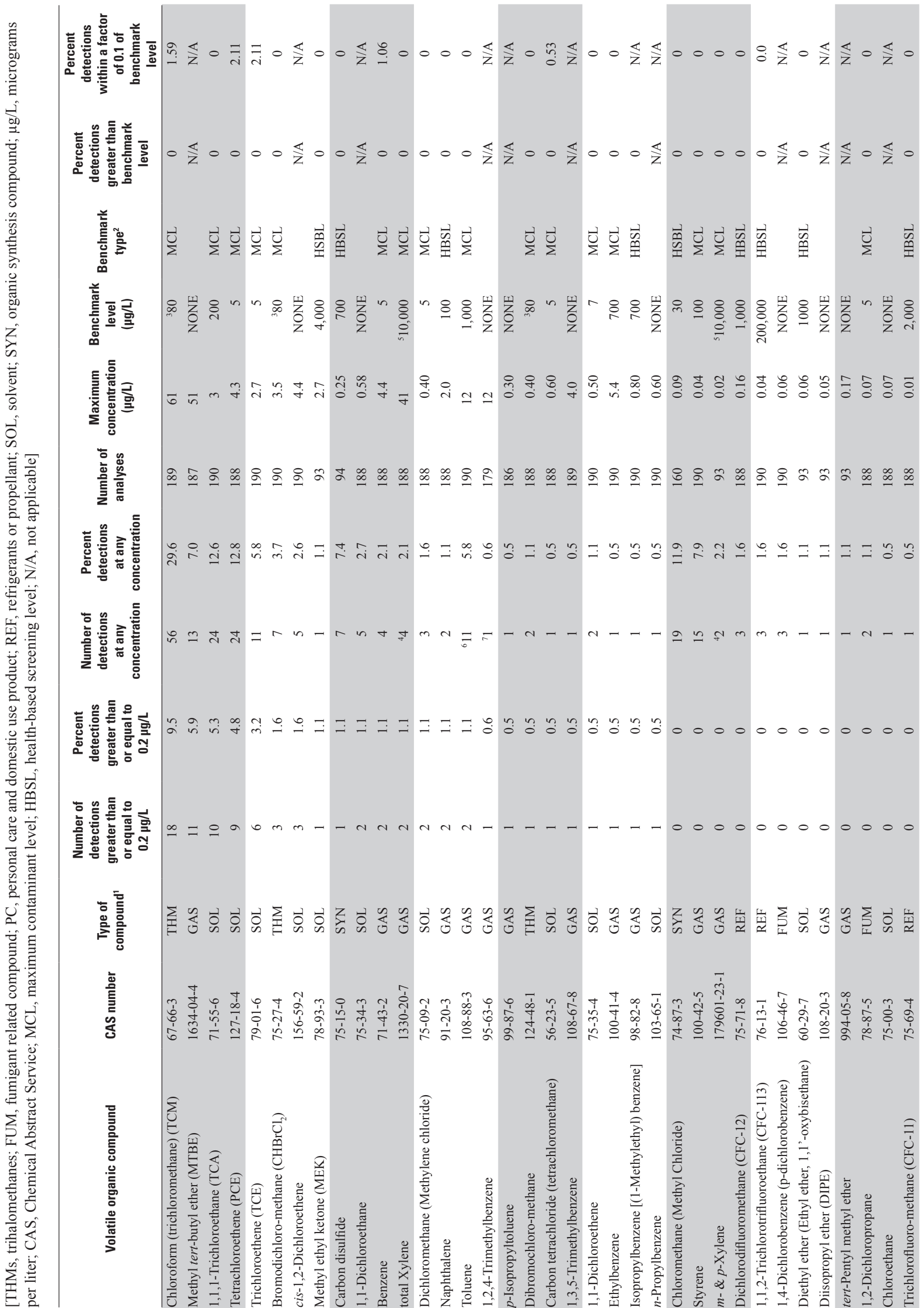




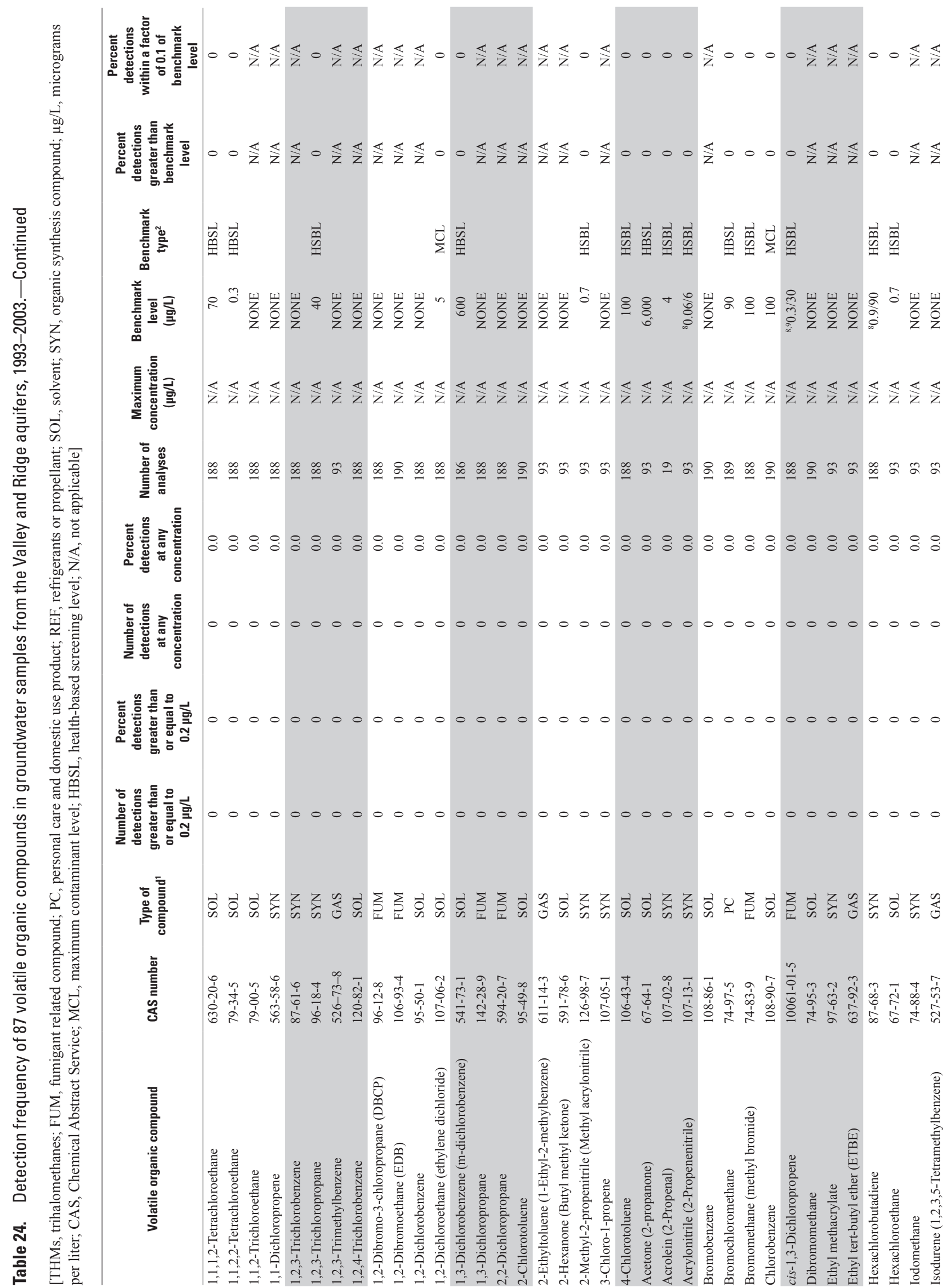




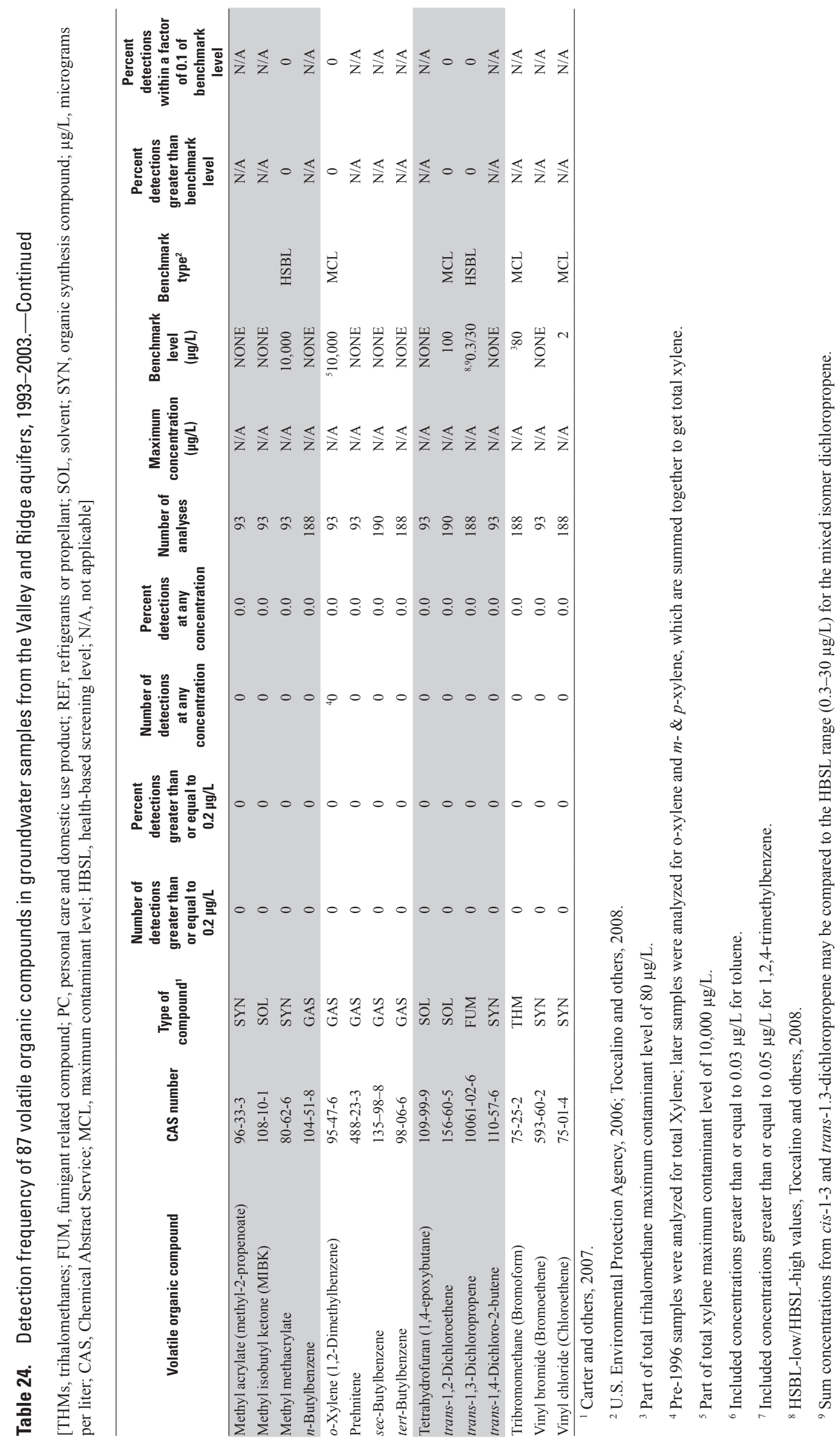


For additional information about NAWQA studies in the Piedmont and Valley and Ridge aquifers contact: Bruce D. Lindsey

U.S. Geological Survey

215 Limekiln Road

New Cumberland, PA 17070

http://water.usgs.gov/nawqa/ 


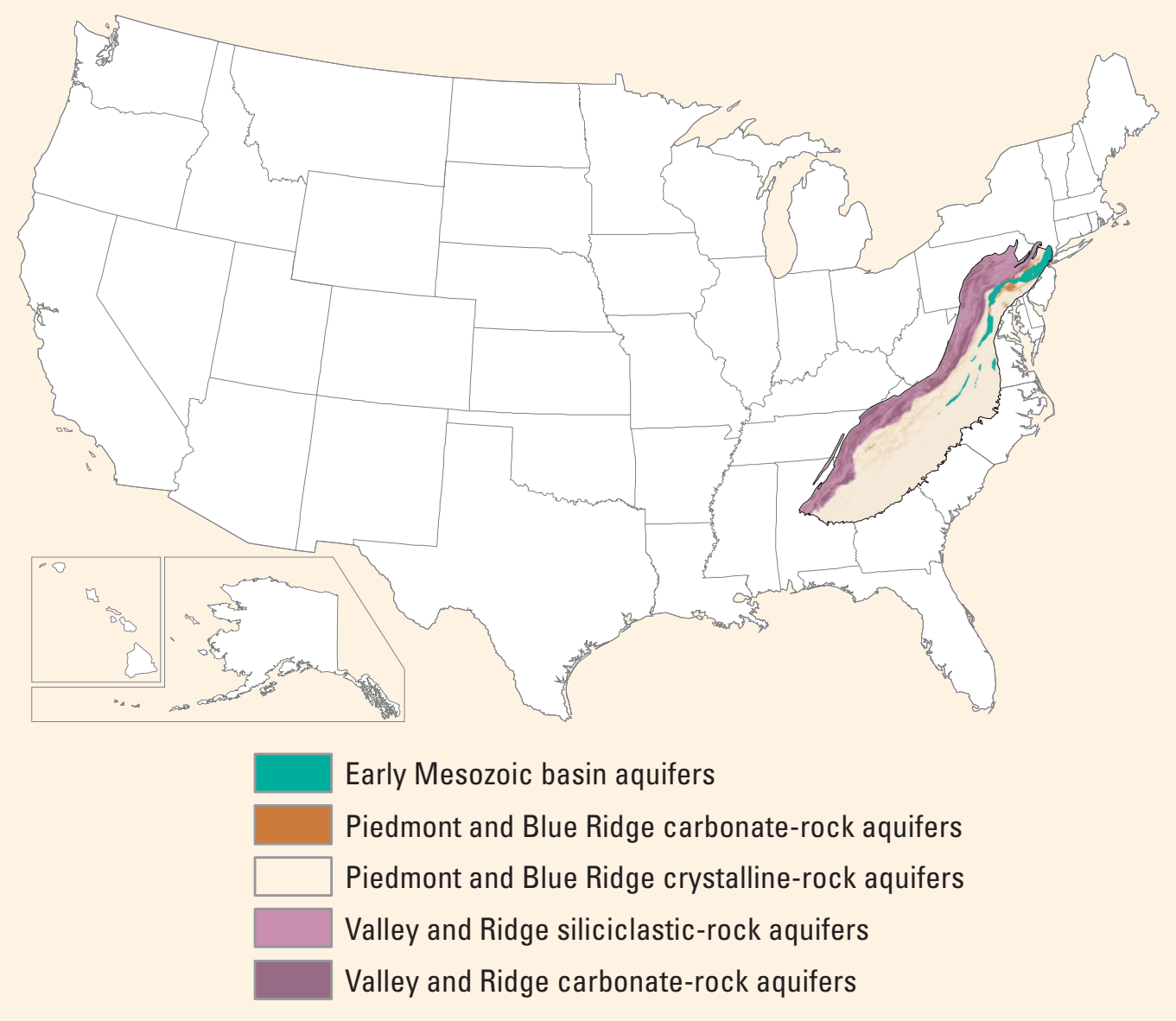

